\title{
WestVirginiaUniversity
}

THE RESEARCH REPOSITORY @ WVU

Graduate Theses, Dissertations, and Problem Reports

2004

\section{Fish use of artificial dyke structures in the Kanawha River, West Virginia}

Jennifer L. Titus

West Virginia University

Follow this and additional works at: https://researchrepository.wvu.edu/etd

\section{Recommended Citation}

Titus, Jennifer L., "Fish use of artificial dyke structures in the Kanawha River, West Virginia" (2004). Graduate Theses, Dissertations, and Problem Reports. 1999.

https://researchrepository.wvu.edu/etd/1999

This Thesis is protected by copyright and/or related rights. It has been brought to you by the The Research Repository @ WVU with permission from the rights-holder(s). You are free to use this Thesis in any way that is permitted by the copyright and related rights legislation that applies to your use. For other uses you must obtain permission from the rights-holder(s) directly, unless additional rights are indicated by a Creative Commons license in the record and/ or on the work itself. This Thesis has been accepted for inclusion in WVU Graduate Theses, Dissertations, and Problem Reports collection by an authorized administrator of The Research Repository @ WVU. For more information, please contact researchrepository@mail.wvu.edu. 


\title{
Fish Use of Artificial Dyke Structures in the Kanawha River, West Virginia
}

\author{
Jennifer L. Titus \\ Thesis submitted to the \\ Davis College of Agriculture, Forestry, and Consumer Sciences \\ at West Virginia University \\ in partial fulfillment of the requirement \\ for the degree of \\ Master of Science \\ in \\ Wildlife and Fisheries \\ Kyle Hartman, Ph.D., Chair \\ Pat Mazik, Ph.D. \\ Dan Cincotta, WV DNR. \\ Division of Forestry \\ Morgantown, West Virginia \\ 2004
}

Keywords: artificial habitat, habitat enhancement, juvenile fish, dykes, large rivers, sunfish, black bass, Kanawha River 


\begin{abstract}
Fish Use of Artificial Dyke Structures in the Kanawha River, West Virginia
\end{abstract} Jennifer L. Titus

Artificial structures have been used in the past to potentially increase fish production by providing cover, feeding grounds and spawning areas. In some areas the US Army Corp of Engineers has constructed dykes to provide additional habitat for river fishes and to mitigate against navigable related impacts. This study is designed to test whether such structures really function as viable habitats as evidenced by increased abundances relative to natural reference areas lacking structures. Five sets of structures in the Kanawha River, West Virginia were sampled via boat electrofishing using pointabundance sampling twice monthly from June through October 2002 and 2003. We found a difference in taxa using structures relative to reference area. Cyprinidae ( $p=0.5$ to 0.1 ) and Catostomidae $(\mathrm{p}=0.1)$ abundance was not dependent on artificial structure in comparison to natural reference. Artificial structures use was most important among Centrarchidae species, especially juveniles, including black bass and several species of Lepomis ( $\mathrm{p}<0.001)$. Further, distribution of fish between areas with and without structures appears most affected by short-term river flow in $2003(p=0.0008)$ where artificial structure serve as flow shelters $(\mathrm{p}=0.0008)$ and in 2002 water temperature $(\mathrm{p}=$ 0.0007). These patterns suggest structures are viable mitigation measures that target and benefit fish of economic interest. 


\title{
Acknowledgements
}

Words cannot express the gratitude and the debt I owe to the following participants for unlimited encouragement, inspiration, and documentation on "the wall."

\author{
Dr. Kyle Hartman \\ Dr. Pat Mazik \\ Dan "the fish man" Cincotta \\ Capt'm John Howell \\ Dr. George Seidel \\ John Niles \\ Kim Bjorgo \\ Mama Hartman \\ Cara Hoar \\ The Girls \\ Barry Passemore \\ Roy and "Roy's on the River"
}

Funding provided by the Army Corp of Engineers, Huntington District

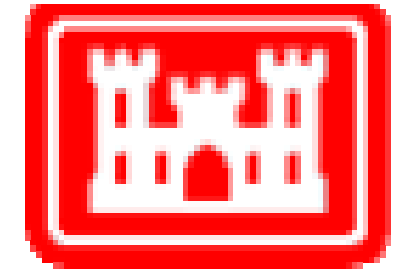




\section{Table of Contents}

Section One: Introduction 1

1.1 The Kanawha River : 1774 - $2004 \quad 1$

1.2 Habitat Heterogeneity in Aquatic Systems 4

1.3 Diel Changes in Habitat Selection 6

1.4 The Effect of River Flow and Temperature on Habitat Selection 7

1.5 Artificial Rock Structures as a Source of Habitat Heterogeneity 9

Section Two: Methods 11

2.1 Study Site 11

2.2 Artificial Structure Characteristics 11

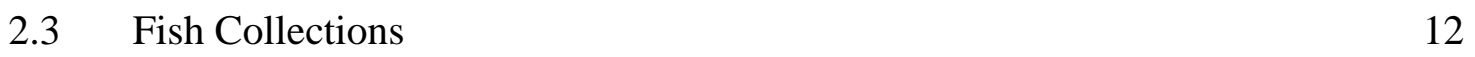

2.3.1 Juvenile Sampling 13

2.3.2 Adult Sampling 14

2.4 River Flow Data $\quad 15$

$\begin{array}{lll}2.5 & \text { Temperature Data } & 15\end{array}$

2.6 Water Quality 16

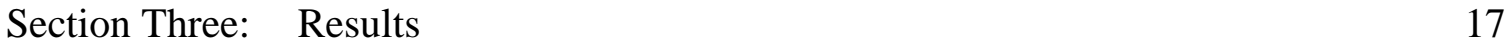

3.1 Fish use of Artificial Structures 17

$\begin{array}{lll}3.2 & \text { Species Richness } & 17\end{array}$

3.3 Species Groups and Artificial Structure 18

$\begin{array}{ll}\text { 3.3.1 Cyprinidae Use of Artificial Structures } & 19\end{array}$

3.3.2 Catostomidae Use of Artificial Structures 20

3.3.3 Centrarchidae Use of Artificial Structures 21

3.3.3.1 Black Basses 21

$\begin{array}{lll}\text { 3.3.3.2 Sunfishes } & 22\end{array}$

3.4 Adult Seasonal Sampling 23

3.5 Individual Artificial Structure Performance 25

3.6 Artificial Structures Provide Low Velocity Zones 26

3.7 River Discharge and Habitat Use 27

Section Four: Discussion $\quad 29$

4.1 Fish Use Artificial Structures as a Source of Habitat 29

4.1.1 River Flow and Artificial Structures 31

4.1.2 Guidelines Set Forth for Artificial Structures 32

4.2 Implications for Management 33

Section Five: $\quad$ Summery 36

Section Six: $\quad$ Literature Cited $\quad 37$

Section Seven: Figures $\quad 43$

Section Eight: $\quad$ Tables $\quad 66$

Section Nine: $\quad$ Appendices $\quad 76$

$\begin{array}{lll}\text { Section Ten: } & \text { Curriculum Vittae } & 89\end{array}$ 


\section{List of Figures}

Figure 1 : The Kanawha River, West Virginia begins at the confluence of the New and Gauley Rivers at the southern most portion of the Kanawha River watershed and flows north until reaching the Ohio River, West Virginia. The Marmet Pool is located between the Marmet and London lock and dams upstream from the city of Charleston and is the second of three pools within the Kanawha River.

Figure 2 : Study Area within Marmet Pool, West Virginia

Figure 3 : Finger Dykes and Zipper Dyke and location of their associated high and low quality natural reference areas within the Kanawha River. Finger Dyke 4 resides upstream from the remaining dykes (see Figure 2). Notice the differences in dyke density between structure types.

Figure 4 : Zipper Dyke and Finger Dyke 1 \& 2 (upper section) and Finger Dyke 2 \& Finger Dyke 3 (lower section) survey map. Notice change of scale from Figure 5 ................................. 47

Figure 5 : Finger Dyke 4 survey map. Note change in scale from Figure 4 . ................................ 48

Figure 6 : Average total catch ( average ( total catch / effort ) among 5 sites combined ) for each sample date within each of artificial structure, high quality natural and low quality natural references sites in 2002 and 2003. Error bars represent 95\% confidence interval. Notice change of y-axis scale from 2002 Day to 2003 Day, 2003 Night.

Figure 7 : Average species richness ( average species richness among 5 sites combined ) for each sample date within each of artificial structure, high quality natural and low quality natural references sites in 2002 and 2003. Error bars represent 95\% confidence interval.

Figure 8 : Average family Cyprinidae ( average Cyprinidae catch (total / effort) among 5 sites combined ) for each sample date within each of artificial structure, high quality natural and low quality natural reference sites in 2002 \& 2003. Error bars represent 95\% confidence intervals. Notice change of y-axis scale from 2002 Day to 2003 Day \& Night.

Figure 9 : Average family Catostomidae ( average Catostomidae catch (total / effort ) among 5 sites combined ) for each sample date within each of artificial structure, high quality natural and low quality natural references sites in 2003. Error bars represent 95\% confidence interval.

Figure 10 : Average juvenile black bass ( average black bass catch (total / effort ) among 5 sites combined ) for each sample date within each of artificial structure, high quality natural and low quality natural references sites in 2002 and 2003. Error bars represent 95\% confidence interval.

Figure 11.: Average juvenile sunfish ( average sunfish catch (total / effort ) among 5 sites combined ) for each sample date within each of artificial structure, high quality natural and low quality natural references sites in 2002 and 2003. Error bars represent 95\% confidence interval. 
Figure 12 : Adult collection fish catches for each sample date. Average fish catch per adult sampling event for artificial structure, high quality natural reference, and low quality natural reference sites in 2003. Error bars represent 95\% confidence intervals

Figure 13 : Average total catch ( average ( total catch / effort ) among all sample dates combined) within each structure type for artificial structure types and the associated natural reference areas in 2002 and 2003. Error bars represent 95\% confidence intervals

Figure 14 : Average species richness (species richness within a site per sample date) within each structure type for artificial structure types and the associated natural reference areas in 2002 and 2003. Error bars represent 95\% confidence intervals.

Figure 15 : Average Cyprinidae (average Cyprinidae within a site / sample date) within each structure type for artificial structure types and the associated natural reference areas in 2002 and 2003. Error bars represent 95\% confidence intervals.

Figure 16 : Average Catostomidae (average Catostomidae within a site per sample date) within each structure type for artificial structure types and the associated natural reference areas in 2002 and 2003. Error bars represent 95\% confidence intervals.

Figure 17 : Average juvenile black bass (average juvenile black bass within a site per sample date) within each structure type for artificial structure types and the associated natural reference areas in 2002 and 2003. Error bars represent 95\% confidence intervals.

Figure 18 : Average juvenile sunfish (average juvenile sunfish within a site per sample date) within each structure type for artificial structure types and the associated natural reference areas in 2002 and 2003. Error bars represent 95\% confidence intervals.............................. 61

Figure 19 : Water temperature (Celsius) representing all sites (artificial structure and high and low quality natural reference sites). Data resulting from logged temperature information October 28, 2002 through March 17, 2004. Temperature was recorded at 2 hour intervals and collected within each site (15 sites total).

Figure 20 : Average velocity (meters/second) within each site and its associated high and low quality natural reference areas for Finger Dyke 1 (FD1), Finger Dyke 2 (FD2), Finger Dyke 3 (FD3), Finger Dyke 4 (FD4), and Zipper Dyke (ZD). Measurements begin near shore (1 meter) and move linearly away from shore (6 meters).

Figure 21 : Mean monthly averages for 2002 and 2003 compared to the historic mean discharge from 1877 to 2002 for the Kanawha River, West Virginia (Data from USGS gage 03193000 Kanawha Falls, WV)...

Figure 22 : Average catch (total catch per site / effort) for artificial structures, high quality natural reference and low quality natural reference for each sample date in relation to river discharge for 2002 day sampling and 2003 day sampling. 


\section{List of Tables}

Table 1 : Structure characteristics for each set of artificial structures. (a.) Measurements within each structure type (feet) and structure density values. See Figure 4 and Figure 5 for the maps from which this data originated. Numbers after each title correspond to the diagram labels below. Density measures are as follows : "Shoreline ft / dyke" = length of shoreline / number of dykes, "Dyke length : distance between dykes" = distance between dykes / average dyke length. (b.) Diagram describes how measurements within table were calculated for each artificial structure site.

Table 2 : Listing of all dates sampling was conducted. Dates are listed for juvenile pointabundance sampling (day 2002, day 2003, night 2003) and for adult transect sampling (adult sample).

Table 3 : Average number of fish collected within study sites for 2002 and 2003 sampling seasons, Kanawha River, Marmet Pool, West Virginia. Average number is total catch in that group divided by the number of sample dates (10 dates in 2003, 6 dates in 2002). Species diversity is strictly the average species diversity within that site. Significant differences between sites are listed ("struc" : artificial structure, "HQ" : high quality natural reference site, "LQ" : low quality natural reference site, "NS" : no difference between any sites. Alpha is $0.05 . \mathrm{p}<.01$ or less in all cases

Table 4 : Sum (sum of five sites) of fish collected using transect method for adult sampling for each sample date in 2003. Fish listed are placed within abundant species groups for each of artificial structure and high and low quality natural reference sites. "Total Catch" is the sum of all fish collected on that date. Species diversity is listed as an average (average among five sites) for that sample date within that site.

Table 5 : Species listing for 2002 day sampling. Numbers are sum of all dates within a site for that species.

Table 6 : Species listing for 2003 day sampling. Numbers are sum of all dates within a site for that species.

Table 7 Species listing for 2003 night sampling. Numbers are sum of all dates within a site for that species.

Table 8 Adult sampling species presence absence data. " $x$ " represents presence of a species within a site at last once during the adult sampling collections (March, June, August, and October 2003)

Table 9 : Average water quality data among all sites for the 2002 and 2003 sampling seasons. Water quality was measured once per site (15 total / sample date) using a YSI water quality meter at 1 meter depth. 


\section{Section One: Introduction}

\subsection{The Kanawha River : 1774 - 2004}

The Kanawha River, West Virginia is a $6^{\text {th }}$ order river beginning at the confluence of the New and Gauley Rivers and flows 97 miles ending where its waters enter the Ohio River at Point Pleasant, West Virginia and regulated primarily for navigation (Sutphin and Andre 1991, Messinger and Chambers 2001) (Figure 1 ). The Kanawha River once premiered as the first navigable regulated waterway in America (Kemp 2000).

Mountains extend nearly to its banks leaving little opportunity for the formation of backwater areas and floodplains (Scott and Nielson 1989).

The Kanawha River, or as it once was referred, “The Great Kanawha” began as a free flowing river with sand bars and large shoals within its path which no doubt provided excellent fish habitat. The first settler of the lower Kanawha came in 1774 and was followed shortly after by the beginnings of the great industrial development of the valley utilizing the rivers’ capacity for shipping goods (Sutphin and Andre 1991).

Navigation needs have fueled changes along the Kanawha River and thus led to the demise if its aquatic life. The need to transport goods began with the initiation of the salt industry in the early 1800s followed shortly after by shipments of coal and timber. Like most of the entire East, the land was stripped of trees, and timber was used as fuel or shipped to the growing cities for construction. Industry growth increased the demand for river "improvements." The first changes to the river began in the 1820s when wing dams were constructed to encourage scouring within the main channel, boulders and debris were removed, and shoals were destroyed (Kemp 2000). 
River regulation began in 1875 with the construction of 10 wicket dams (Kemp 2000). These retained water for increased depth while still allowing boats to pass. By the 1920s, the first constructed wicket dams had begun to deteriorate, navigation pressure continued to increase, and again the Great Kanawha prepared for additional changes. In the 1930's the ten wicket dams were removed in exchange for four roller gate lock and dams (London, Marmet, and Winfield lock and dams on the Kanawha River and Robert C. Byrd, Gallipolis, WV on the Ohio River). River depth increased to nine feet and the capacity to regulate flow was improved to keep river levels nearly constant. Power generation plants were incorporated with the London, Marmet, and Winfield lock and dams benefiting from the constant river flow (Kemp 2000). The result was a completely altered physical habitat for fish with reduced habitat complexity, higher flows, and decreased river bank surface area.

The Kanawha River valley and the development of its waterway attracted industrial development. Coal corporations found high quality coal seams with much less expensive acquisition costs in comparison to the Monongahela coals just to the north (Great Kanawha Navigation Company 1868). With navigational improvements, low cost, and access to near-by large cities, industrialization along the Kanawha River continued. Coal companies flocked to the valley and coal shipments on the river grew nearly exponentially. Chemical industries moved in during the turn of the century utilizing the river for shipments and the area's abundance of natural resources (Hubacher and Wintz 2003).

The first official reports of declining fish populations occurred in 1907. The U.S. Bureau of Fisheries cited causes due to mining development, timbering, chemical industry, and occasional use of dynamite for fishing (Addair 1944). Chemical pollution became a major problem in the decades to follow. Fish populations dropped in the lower reaches of the Kanawha River as chemical factory effluent poured waste almost directly into the river. In addition, development along the river banks had direct sewage and water waste inputs. Forest removal throughout the entire valley caused high sediment loads into the mainstem and adjacent tributaries. Addair (1944) collected few fish in the mainstem in 1942. The few fish captured were located near tributaries where chemical concentrations were diluted. Native populations, such as paddlefish (Polyodon spathula) 
and smallmouth bass (Micropterus dolomieu), were visibly suffering from chemical poisoning. In addition, channelization, and the removal of shoals, sand bars, and debris decreased available habitat. Addair (1944) pointed to several factors in the demise of Kanawha River aquatic populations. The greatest issues related to its lack of vegetation and pollution problems in addition to few floodplain connections and heavy siltation. These, in combination with the newly altered flow regime, allowed fish populations little opportunity to survive. Chemical pollution continued into the 1970s. In the early 1980s, chemical inputs decreased enough for the river to begin its recovery (Kuntz 2003).

The Kanawha River is currently recovering from a century long fight with human induced alterations. The later 1980s showed fish populations on the rise with game species doing extremely well (Scott 1988). Today the chemical pollution is reduced, surrounding lands are reforested, and mining continues, but with stiffer regulation. Navigation continues with coal and chemicals being the most prominent shipments. Once again the Kanawha River is undergoing alterations to allow for increased travel. The U.S. Army Corp of Engineers (USACE) is conducting lock and dam expansions of which the Winfield lock is completed, the Marmet lock underway and London lock expansion pending.

Every change made to the river has inevitably had an impact on fish populations. However, this time the USACE is attempting to mitigate impacts to aquatic life in its expansion plans. In relation to the Winfield expansion, the effect of increased barge travel on larval fish was considered (Odom 1987), as well as the importance of flooded tributary mouths to their survival (Scott 1988), since these tend to be important in young fish survival and overall recruitment.

Channelization and maintenance dredging has reduced the availability of good quality fish habitat in the lower Kanawha River. The main channel often has swift flows and its homogeneity offers few areas of cover or low flow within its entire length. The little heterogeneity that does exist is provided within the few islands, riparian vegetation overhanging with logs and snags along the river edge, and flooded tributary mouths. It seems that the Kanawha River fish populations, although recovering, are probably limited by the amount of available habitat. As boat traffic continues to increase, the need for cover from waves and turbulence will be essential. 
As a result, in response to the Marmet lock and dam expansion, a series of artificial rock structures were constructed in 2000 within the Marmet pool. These structures were designed to provide habitat for young and small fish that are adversely affected by the existing and expected river conditions. In fact, these structures may help offset losses of the shoals and sand bars that existed previous to the river's harnessing. The USACE hopes that these structures will mitigate the effects of the river expansion and allow increased recruitment by populations in the future. This study examines the use of these structures by fish in 2002 and 2003. In addition, more structures are anticipated at other sites within the Marmet pool in the near future.

\subsection{Habitat Heterogeneity in Aquatic Systems}

River channelization and channel clearing for efficient navigation and regulating flows create, unnatural homogeneous habitats compared to pre-impoundment conditions. World-wide, through human alterations, rivers have been changed from their original wide, shallow, meandering morphology to deep, narrow, straight systems to fulfill the needs of development (Aarts et al. 2004). As a result, many river systems struggle with poor or declining populations of aquatic fauna (Stanford 1996, Cowx 2002, Pretty et al. 2003). Since large rivers are unlikely to be restored to pre-impoundment conditions, "habitat enhancement" structures have been incorporated into fisheries management as a tool to create alternatives for habitat heterogeneity. These features will hopefully benefit aquatic species and mitigate the changes made to the river (Sheehan and Rasmussen 1999). Heterogeneous habitats are crucial for fish populations because they provide cover from predation and river flows, increase forage availability, and improve juvenile fish survival. The use of habitats types can vary by species, river conditions, or light levels.

Large rivers changed world-wide with the growth of industry, agriculture, and urban development, and may be regulated by dams for navigation, flood control, water supply, recreation, or power generation. Channelizing and straightening rivers adversely affects fish by decreasing habitat complexity and diversity along shallow water edges and 
other flooded zones where crucial habitats are limited (Madejczyk et al. 1998, Robichaud-LeBlanc and Courtenay 1998, Langler and Smith 2001, Pretty et al. 2003). Backwaters provide ideal habitat where rivers interact with floodplains and, in addition to islands and coves, provide refuge from the main channel. Upon channelization, the mouths of tributaries are flooded and are typically utilized as fish habitat. Often large river systems are limited by the amount of such habitat provided (Nunn et al. 2003). The extreme solution is to remove the dams and allow the system to repair itself. However, in many systems, human dependence on the waterway will not allow for this option.

Habitat heterogeneity is essential for fish populations. A loss of heterogeneous habitats has been found to negatively affect fish and invertebrate populations in both diversity and abundance (Madejczyk et al. 1998, Langler and Smith 2001, Pretty et al. 2003). There are two major benefits that heterogeneous habitats provide. First, they may afford refugia from predation and environmental variables such as river flows. Prey cover decreases the ability of predators to both see and catch prey (Savino and Stein 1989, Walters et al. 1991, Lehtinen et al. 1997, Takemon and Nakanishi 1998). Second, heterogeneity tends to create higher overall productivity and concentrates food sources for many different species. Piscivores benefit from higher numbers of small fish near cover, which increases encounter rate. Omnivores and insectivores benefit from a greater surface area available for invertebrates and macrophytes (Pardue 1973, Gannon et al. 1985, Walters et al. 1991, Moring and Nicholson 1994). Heterogeneity may exist through woody debris, cobbles, artificial structures, or vegetation. Artificial habitats, such as dykes and groins, offer a source of heterogeneity in large rivers that have few forms of habitat diversity (Nicholas and Pont 1995, Poizat and Pont 1996).

Heterogeneous habitats are most crucial for juvenile fish (Pretty et al. 2003). Cover and increased forage aids in the survival of young fish. Juvenile fish prefer habitats with increased forage, plentiful cover, and littoral zones or backwater areas (Aggus and Elliott 1975, Scott 1988, Lobb and Orth 1991, Rountree and Able 1992, Skov and Berg 1999). Young fish are highly susceptible to predation, and cover allows them to increase their survival rate. Increased forage in heterogeneous habitats, and included in a range of juvenile fish diets, may encompass macrophytes and other primary producers, zooplankton, invertebrates and crayfish. The easiest way to compensate for the impacts 
of human alterations on fish abundance may be to increase young fish survival (Letcher et al. 1997). An increase in heterogeneity, targeted to benefit young fish, could potentially create an increase in localized fish production due to more fish reaching maturity (Letcher et al. 1997, Walters and Kitchell 2001, Pretty et al. 2003).

More than any other group of fish, juvenile Centrarchidae species (black basses and sunfish) have been found to consistently prefer areas of higher complexity, which are linked to woody debris, rocks, or submerged vegetation (Prince and Maughan 1979, Gannon et al. 1985, Lobb and Orth 1991, Poizat and Pont 1996, Johnson and Jennings 1998, Scott and Angermeier 1998). Centrarchidae commonly prefer areas that provide cover and abundant components of their diet (aquatic and terrestrial insects), and are therefore more common in heterogeneous habitats. Centrarchidae species are popular sport fish in temperate rivers of North America. Since Centrarchidae typically have the highest association with heterogeneous habitats, the management of these habitats may be crucial to the sport fish industry (Lobb and Orth 1991).

\subsection{Diel Changes in Habitat Selection}

Complex littoral zones play an important role in the diel migration of fishes. Aquatic species activity varies with changes in light levels (Johnson and Covich 2000). Typically, fish population assessments record higher species richness and abundance at night than during the day. The highest activity occurs just after dusk and before dawn as fish move into littoral zones and sources of cover (Emery 1973, Sanders 1992, Albert and Bergstad 1993). Heterogeneous littoral zones may increase the degree of these diel migrations (Moring and Nicholson 1994).

Diel changes in habitat use differ between fish size, species, or groups (Copp and Jurajda 1993, Slavik and Bartos 2000). Family Cyprinidae species, including shiners and chubs, typically alter their schooling behavior with changes in light levels, but vary little in habitat selection (Emery 1973, Odom 1987). Family Catostomidae species, encompassing large sucker fishes, increase feeding at night and move to littoral zones (Emery 1973, Madejczyk et al. 1998). Family Centrarchidae species move to littoral 
zones at night even more than day and have been observed to take advantage of high insect and crayfish levels that lie within heterogeneous littoral zones (Emery 1973, Odom 1987, Moring and Nicholson 1994, Scott and Angermeier 1998).

\subsection{The Effect of River Flow and Temperature on Habitat Selection}

The flows of regulated rivers are determined by the needs of its users, and are often characterized by spikes or dampened extremes in flow by dams. In a natural system, waters spread out into the floodplain during higher flows. In regulated rivers, however, flows are restricted to the straightened channel where waters rush down the center with high velocity and can cause unnatural, rapid changes in temperature (Beebe 1996).

There is a physiological link between fish and temperature. Warmer temperatures result in increased consumption, higher metabolism, and thus increased growth (Kitchell 1977, Stanford et al. 1996). Often the years of greatest fish production are associated with higher temperatures (Langler and Smith 2001, Nunn et al. 2003). Extreme changes in temperatures, even just a few degrees, can cause physiological stress increasing susceptibility to disease and ultimately mortality (Jobling 1995).

River flow has a physical effect on fishes and other aquatic life, especially for young-of-the-year and juvenile fishes. High flows cause fish to be washed downstream (Cowx 2002). Early life stage survival is significantly reduced during periods of higher flow versus low flow (Freeman 2001, Humphries et al. 2002). High flow also increases the energy needed for fish to maintain position; therefore, growth during high flow periods is typically less (Nunn et al. 2003). Higher flows may decrease food sources by detaching benthic organisms and washing out detrital food sources (Hershfeld et al. 1986, Nunn et al. 2003). In addition, high flows increase the rate of erosion, increase turbidity, and decrease macrophyte growth (Lobb and Orth 1991).

Nunn et al. (2003) hypothesized that during periods of low flow, temperature determines the success of fish in terms of survival; however, when flows are high the rate of discharge determines fish survival. In essence, low flows allow higher temperatures 
and increased growth which results in strong year classes. Conversely, during high flows fish survival is low and correlated with weak year classes (Humphries et al. 2002, Grift et al. 2003). Since production depends on the ability of fish to both survive and to reach maturity, the correlation with discharge and temperature is crucial in management of lotic fisheries (Halls et al. 2000, Magoulick and Kobza 2003).

Heterogeneous habitats, including complex littoral zones or backwater areas, create shelter from high velocities thus increasing the chance of survival of fish (Muhar 1996). Juvenile fish in particular have been found to move into natural or artificial habitats that serve as protection during higher flow events (Lehtinen et al. 1997, Freeman et al. 2001, Langler and Smith 2001, Chovanec et al. 2002, Giannico and Hinch 2003, Grift et al. 2003, Pretty et al. 2003). The integration of artificial habitats to increase habitat heterogeneity, and in this case creating protection from flows, can potentially influence the survival of fish in systems subject to irregular flows. 


\subsection{Artificial Rock Structures as a Source of Habitat Heterogeneity}

Many large rivers have used rock structures as artificial habitats. Rocks are piled to form dykes or groins. Interstitial spaces within these structures are used as cover for small fish and other organisms. The large surface area is covered with algae and attached invertebrates. The low velocity waters between structures provide protection from the main channel flows. Structures may also provide areas of higher temperatures than the main channel. Assessment of these structures shows some success (Moring and Nicholson 1994, Nicholas and Pont 1995, Poizat and Pont 1996,). Juvenile Centrarchidae species, especially sunfish, benefit most from these structures (Bohnsack et al. 1991). In European Rivers, pumpkinseed (Lepomis gibbosus) showed the most preference for artificial rock structures (Poizat and Pont 1996). North American rivers showed similar results. Sunfish, such as bluegill (Lepomis macrochirus) and green sunfish (Lepomis cyanellus), showed the largest preference for artificial structures (Poizat and Pont 1996, Bohnsack et al. 1991). Bass, including smallmouth (Micropterus dolomieu) and spotted bass (Micropterus punctulatus), used these areas as well.

Fisheries managers should follow guidelines to best utilize artificial habitat alteration or enhancement as a tool to improve fisheries in impacted systems. Steimle and Zetlin (2000) have outlined a series of guidelines that should be considered when planning artificial habitat enhancement. They advocate that artificial habitats should: (1) act as corridors between habitat types (here shoreline and main channel); (2) maintain population diversity for all types of organisms; (3) provide refuge from predation; (4) expand highly utilized habitats for spawning or forage; (5) allow public fishing access; (6) commensurate nutrient removal by benefiting filter feeding organisms; (7) compensate for lost habitats; and, (8) be applicable to continued research. Artificial rock habitats, if placed correctly, have the potential to fit all of their outlined needs. This stresses the need to consider the system in mind because not all artificial improvements work well. In addition to Steimle and Zetlin's (2000) artificial habitat criteria, another key feature is the inclusion of natural attributes, such as the use of local materials or 
natural vegetation, to further increase heterogeneity and fulfills long-term and esthetic considerations (Lobb and Orth 1991).

We aim to dissolve the use of artificial structure areas in comparison to natural reference areas in a regulated river system. The artificial rock structures the USACE constructed in 2000 within the rivers littoral zone of the Marmet pool are designed to increase habitat heterogeneity and attain the benefits associated with greater habitat diversity. This study is designed to examine fish use of artificial structures in comparison to natural reference areas. In addition, we examine how fish habitat selection, both overall and within groupings of fishes, varies with diel changes, and response to river flow and temperature. Our objectives are to :

1. Determine fish use of the five sets of artificial structures constructed in the Marmet Pool, Kanawha River.

2. Compare fish use of artificial structures to high and low quality natural reference areas.

3. Examine the artificial habitat use of fish relative to diel variation, river flow and water temperature. 


\section{Section Two: Methods}

\subsection{Study Site}

This study takes place in the Marmet pool of the Kanawha River, West Virginia. The Marmet Pool is just upstream from the city of Charleston, West Virginia (Figure 1). Sections near the city of Charleston are highly industrialized. The banks are steep with a relatively short submerged shelf width. Fine sediment dominates the substrate and there are few backwater areas or places that would provide cover for fish beyond flooded tributary mouths (Scott and Nielsen 1989).

The USACE, Huntington District, is conducting a large scale project to renovate its locks and dams to allow for greater barge traffic. The increased barge traffic could negatively impact fish populations, especially larval and juvenile stages (Scott 1988, Rider and Margraf 1997). Artificial structures were constructed in the Kanawha River by the USACE in 2000 as mitigation to offset the effects of the expansion project.

\subsection{Artificial Structure Characteristics}

Five sets of artificial structures were constructed. Four Finger Dykes (FD1 - FD4) and one set of Zipper Dykes (ZD) (Figure 2). Each set varied in size and length but was made of similar material. Structure designs were somewhat different (angle from riverbank, distance between individual dykes, and length of dykes) (Figure 4 \& 5); however, each achieved a goal of increasing complexity greater than their associated reference areas. Artificial structures were dominated by the rocks used for construction, but also had some low hanging vegetation and woody debris. Two reference areas were selected to compare with each structure: one of high quality natural composition and one of low quality natural composition. 
The artificial structure sites each consisted of a series of dyke structures. All dykes were constructed of rock/rubble material positioned along the shoreline and extending into the river along the bench. The Finger Dykes were angled from shore while the Zipper Dykes were positioned parallel to shore. Each structure, although different, did at minimum provide a greater habitat heterogeneity and higher amount of cover within each of them than what was available naturally and most of the time dykes performed similarly. However, since each artificial structure type was slightly different in design (Figure 4 and 5), (size of dykes, density of dyke structures) each varied in their attraction to fish and thus it may be important to examine differences among structures if we are to learn how to best design artificial structures in the future.

The artificial structure types construction design varied between sites (Table 1). The shoreline length of each artificial structure site was 400 to 700 feet. The greatest density of structure material within a site occurred within Finger Dyke 2 (37 feet of shoreline / dyke and 1.6 feet between dykes / average dyke length). The Zipper Dyke was the next densest followed by Finger Dyke 1, and lastly Finger Dyke 4 and Finger Dyke 3 (75 feet of shoreline / dyke and 1.0 feet between dykes / average dyke length). Although Finger Dyke 4 appears similar to Finger Dyke 3 in the amount of habitat provided, little of Finger Dyke 4 was submerged during normal flows thus the habitat available within that site was less. Although the Zipper Dyke Structure had the shortest shoreline length, the design created the highest dyke length / distance between dyke value, and the site provided a large amount of heterogeneous habitat as a result.

\subsection{Fish Collections}

Sites were assessed via DC electrofishing using a point-abundance scheme. Point abundance sampling is effective in catching juvenile and small fish (Pretty et al. 2003). Electrofishing was conducted using a Smith-Root standard electrofishing boat. Samples consisted of maneuvering the boat perpendicular to shore with probes positioned directly in front of the boat. Moving into shore slowly, power was not applied until the probes were in the desired location. Duration of power application with electrofishing varied for 
each replicate to allow all visible fish to be collected at that point; however, we kept efforts relatively similar within dates. Upon surfacing, fish were netted and kept alive on board in holding tanks until all replicates were completed at a site. This avoided multiple catches of the same fish and allowed a recovery period for stunned fish.

For standardization, we used the same netter within each collection date. Each set of Finger Dyke structures and two associated reference areas were sampled using 6 point sample replicates. The Zipper Dyke structure and two associated reference areas had four replicates each, since this area was smaller than the Finger Dyke areas. Comparisons of fish use of structures versus natural reference sites were made using an average number of fish captured per site; this was calculated from the total catch at a site divided by the number of replicates ( 4 or 6 replicates) to compensate for the lower effort at the Zipper Dyke sites (4 replicates).

Two reference sites are associated with each artificial structure for a total of 15 sites (Figure 3). For each artificial structure, data from one high quality natural reference site and one low quality natural reference site are compared. This allows us to see the apparent selection by fish for habitat on a small continuum and further develop which attributes of structure are most important. High quality natural reference areas had a large shelf width (similar to the artificial structure sites) and typically had woody debris, snags, aquatic vegetation, low hanging vegetation, and lower water velocity in comparison to low quality reference sites. Low quality natural reference areas had fewer snags and woody debris, vegetation was not as low hanging to the water, aquatic vegetation was rare, and water velocity was higher than in high quality natural reference sites.

\subsubsection{Juvenile Sampling}

Following captures, fish were identified and returned to the river. When large fish species were unidentifiable in the field they recorded to genus and released. Unidentifiable small fish were preserved in 8\% formalin solution and brought back for lab identification. Total lengths ( $\mathrm{mm}$ ) were recorded for all fish. Site specific data were 
analyzed using ANOVA/GLM model in SAS. Two parameter comparisons were analyzed using students t-test (Zar 1999). All alphas were set at 0.05 and for each analysis we tested for normality using skewness and Kurtosis. Data not found to be normal were transformed using a log base 10 transformation.

Members of family Centrarchidae were determined to be juvenile or adult using a combination of length frequency analysis and general life history information. Black basses were assumed to reach maturity at age 3 and $191 \mathrm{~mm}$ (Etnier and Starnes 2001, Jenkins and Burkhead 1993). Black bass above $191 \mathrm{~mm}$ were listed as an adult and those below were listed as a juvenile. Sunfish species were determined to be juveniles or adults in a similar fashion and were determined to be adults when greater than $120 \mathrm{~mm}$ corresponding with a typical age two (Etnier and Starnes 2001, Jenkins and Burkhead 1993).

Collections consisted of both day and night sampling events in order to evaluate diel habitat use (Table 2). Day sampling typically occurred twice monthly and was conducted in the early afternoon on each date. The 2002 sampling season included day sampling only and occurred on six dates from July through October 2002. The 2003 day sampling occurred on ten dates from June through October. Night samples were conducted during the 2003 sampling season only and occurred once monthly on five dates from June through October 2003. Night sampling began just after dusk.

\subsubsection{Adult Sampling}

In addition to juvenile sampling, we examined adult species use of structures and reference areas with data collected in March, June, August, and October 2003 (Table 2). Sampling was designed to be qualitative information additional to the juvenile information. Adults were collected via electrofishing at the same sites using the same equipment as juvenile sampling regimes. Instead of using point abundance, we used a transect method, shocking waters along the edge of the structures in order to collect larger adult fish that may be present immediately adjacent to the structures. At each site we ran an approximately 100 meter transect for about 4 minutes. Transects were 
repeated three times with identical starting points. During each transect fish were netted and retained on board in holding tanks until all three transects were completed. As with juvenile sampling methods, fishes were identified to species, large unidentifiable fish were recorded to genus, small unidentifiable fish were retained for lab identification, and total length were recorded for all fish (mm).

\subsection{River Flow Data}

The river flows during the two sampling years represented two extremes in flow regime, one of low flows (2002) and one of high flows (2003) with associated changes in fish habitat use. Since these patterns occurred in back to back years, it was necessary to include the effect of river flow into the analysis of fish collections. River flow analysis was done using discharge data collected by the United States Geological Survey (USGS) and provided in hourly format by the United States Army Corp of Engineers (USACE). Discharge data were collected by a USGS gage at Kanawha Falls, WV (USGS gage 03193000). Discharge data were not available for the Marmet pool itself. The Kanawha Falls gage is upstream of the Marmet pool, but in comparing the stage heights of the pool (stage height data supplied in hourly format from the USACE) and other nearby USGS gage information, the Kanawha Falls gage most closely resembled the Marmet pool stage height over any other available data sources including Kanawha River at Charleston, WV (USGS gage 03197990) and Coal River at Tornado, WV (USGS gage 03200500). In addition the USACE listed Kanawha Falls in its list of recommended gage selections for our causes (Kimberley Bacon, LRH, USACE Huntington District, personal communication, USACE).

\subsection{Temperature Data}


Temperature loggers ( Model : HOBO Water Temp Pro [H20-001] ) were placed at each site (artificial structures and reference areas for a total of 15 loggers) and recorded the water temperature every two hours. Temperature was collected from October 2002 through the latest download date of 17 March 2004. The loggers are still in place and continue to log temperature data. The loggers were set in place after the 2002 sampling season. Prior to installing temperature loggers we manually recorded temperature at each site on each sample date (see "Water Quality”).

\subsection{Water Quality}

In addition to temperature logger information, we measured water quality at each site (artificial structures and reference areas for a total of 15 measurements) on each sample date. Water quality was measured using a YSI meter (Computer module : 650 MDS, Sonde : 6820 ). Measurements were taken within each site at $1 \mathrm{~m}$ depth. Water quality measurements included dissolved oxygen (mg/L), turbidity (NTU), temperature (Celsius), conductivity (mS/cm), specific conductivity $\left(\mu \mathrm{S} / \mathrm{cm}^{\mathrm{c}}\right), \mathrm{pH}$, and salinity (ppt). Dissolved oxygen was calibrated before use on each sample date and all other variables were calibrated at the start of the sampling year. There was no significant difference within each sample date in any of the water quality measurements between sites (artificial structure versus high and low quality natural reference sites and between structure types). 


\section{Section Three: Results}

\subsection{Fish use of Artificial Structures}

Fish used the introduced artificial structures as a source of habitat (Figure 6). Collections made over two sampling years (2002 and 2003) show 44\% of the total catch each year (sum of total catch for all sample dates within each year) were associated with artificial structures in comparison to two near-by natural reference habitats. Fish were significantly less abundant in low quality natural sites than in high quality natural sites and artificial structures ( $\mathrm{p}$ 0.001) in both 2002 and 2003 (Table 3). Low quality natural sites contained $17 \%$ of the total catch collected in comparison to high quality natural sites housing 38\% of the total catch collected. However, the total catch in 2002 and in 2003 did not differ significantly between artificial structures and high quality natural sites. Artificial structures provided a habitat that, among the total catch, was selected equally in comparison to high quality natural reference sites.

Artificial structure use by fish was greater at night in 2003 (Figure 6). Fish were collected more at night versus day sampling in 2003 within all treatments (artificial structure and references) (Table 3). The average catch (all structure and reference sites combined) between sample dates at night was 367 fish versus 168 fish during the day. During night collections, artificial structures contained significantly more fish than high quality natural sites $(\mathrm{p}<0.05)$. Artificial structures and high quality natural sites were selected significantly more than low quality natural sites $(\mathrm{p}<0.001)$. Artificial structures showed the greatest difference between day and night collections $(\mathrm{p}<0.001)$, while high and low quality natural sites were different to a lesser degree $(\mathrm{p}<0.01)$.

\subsection{Species Richness}


Species richness within artificial structures was greater than or equal to high quality natural reference sites during day sampling (Figure 7). In 2002 species richness was significantly greater on artificial structures than in natural habitats $(\mathrm{p}<0.001)$ averaging 7 species on artificial structures versus 5 species in high quality natural sites and 4 species in low quality natural sites. The second sampling season consisted of an overall lower yield of fish and was correlated with a decrease in species richness at all sites. Species richness was significantly less in 2003 at the low quality natural sites than high quality natural sites and artificial structures $(\mathrm{p}<0.001)$ but richness did not differ between high quality natural and artificial structures. Species richness during 2003 averaged 4 fish on artificial structures, 4 fish in high quality natural sites, and 3 fish in low quality natural sites (Table 3).

In 2003, species richness nearly doubled at night versus day sampling $(\mathrm{p}<0.001)$ (Figure 7). The distribution of species richness between sites remained the same where artificial structures and high quality natural sites were not different, but were both significantly greater than low quality natural sites $(\mathrm{p}<0.0001)$. At night, species richness on artificial structures averaged 10 species while during the day averaged 4 species (Table 3). The average species diversity in high quality natural sites at night was 9 species versus 5 species during the day, and low quality natural sites averaged 5 species at night versus 3 species during the day.

\subsection{Species Groups and Artificial Structure}

Fishes collected were typical of large river systems with individuals from families Cyprinidae, Catostomidae, and Centrarchidae being the most abundant. Other common species, yet not part of those families, include sauger (Sander canadense), logperch (Percina caprodes), freshwater drum (Aplodinotus grunniens), channel and flathead catfish (Ictalurus punctatus and Pylodictis olivaris), and gizzard shad (Dorosoma cepedianum) (Tables 5, 6 \& 7). Each of Cyprinidae, Catostomidae, and Centrarchidae families differ in their preference for habitat, thus their distribution among study sites 
differs. Below we examine the changes in habitat selection among these families and their use of the artificial structures.

\subsubsection{Cyprinidae Use of Artificial Structures}

Cyprinidae were collected equally among artificial structures and high quality natural habitats (Figure 8) during day samples. Cyprinidae were collected in low quality natural sites significantly less than in high quality natural reference sites and artificial structures during both 2002 and 2003 sampling seasons $(\mathrm{p}<0.001)$ suggesting that there is some need for cover or habitat heterogeneity (Table 3). However, there was no difference in Cyprinidae use between artificial structures and high quality natural habitats in 2002 or 2003.

Similar to day collections, Cyprinidae were collected equally among artificial structures and high quality natural habitats during night samples (Figure 8). Low quality natural sites had significantly fewer Cyprinidae than high quality natural sites and artificial structures $(\mathrm{p}<0.001)$. High quality natural sites were not significantly different from artificial structures. However, Cyprinidae catches were typically greater in high quality natural sites than in artificial structures. More Cyprinidae were collected at night where the average Cyprinidae catch (total Cyprinidae among all sites per sample date) was 150 fish versus 69 Cyprinidae during the day.

We collected twelve different species of Cyprinidae (Table 5, 6 \& 7). The most abundant species were channel shiner (Notropis vollucellus wickliffi) and emerald shiner (Notropis atherinoides). There were some species collected only within one sample year. Cyprinidae species collected in only 2002 were central stoneroller (Campostoma anolmalum), steelcolor shiner (Cyprinella whipplei), and silver shiner (Notropis photogenis). Additional species collected only during the 2003 sample season included whitetail shiner (Cyprinella galactura), spottail shiner (Notropis hudsonius), and big eye chub (Hybopsis amblops). Whitetail shiner was moderately abundant in 2003, but was collected during day sampling only. 


\subsubsection{Catostomidae Use of Artificial Structures}

Catostomidae species commonly collected included smallmouth buffalo (Ictiobus bubalus), golden redhorse (Moxostoma erythrurum), silver redhorse (Moxostoma anisurum), and river carpsucker (Carpiodes carpio) (Tables 5, 6 \& 7). Although pointabundance collection methods were not geared toward collections of larger fish, it was effective at collecting several of these species. Comparisons here are made in only 2003 as large fish were not consistently collected in 2002.

Catostomidae abundance on artificial structures was not significantly different from high quality and low quality natural sites (Figure 9). Low quality natural habitats housed significantly fewer Catostomidae fish than high quality natural sites $(\mathrm{p}<0.001)$. Although not significant, the highest abundance of Catostomidae species occurred within high quality natural reference sites (average 5 fish), and less within artificial structures (average 3 fish) and low quality natural reference sites (average 1 fish) (Table 3).

Catostomidae were significantly more abundant at night than during the day $(\mathrm{p}<$ 0.0001), but their abundance did not rely on artificial structures (Figure 9). Typically night catches of Catostomidae species were 4 times greater than day catches (total all sites average 8.8 fish during the day versus 39.6 fish at night per sample date). Low quality natural sites contained significantly fewer Catostomidae species than did artificial structures and high quality natural sites $(\mathrm{p}<0.001)$. Catostomidae abundance on artificial structures and high quality natural sites was not significantly different. However, on average Catostomidae species were found in greater numbers in high quality natural sites (5 during the day, 19 at night per sample date) than on artificial structures (3 during the day, 15 at night per sample date) (Table 3). Low quality natural sites held the lowest abundance (1 during the day, 6 at night per sample date).

During the study we found several young Moxostoma species ( $<200 \mathrm{~mm})$, most of which were golden redhorse. We collected these most commonly at night, but were spread evenly between artificial structures and high quality natural sites with few collected in low quality natural sites. 


\subsubsection{Centrarchidae Use of Artificial Structures}

Centrarchidae species distribution appears to be most affected by the introduction of artificial structures in comparison to other abundant fish groups. Centrarchidae, many of them juvenile, were found to have highest abundance on artificial structures versus natural high and low quality reference areas in comparison to other species groups. Below we break down Centrarchidae use into black bass (spotted bass, Micropterus punctulatus and smallmough bass, Micropterus dolomieu) and sunfish use (green sunfish, Lepomis cyanellus, bluegill, Lepomis macrochirus, longear sunfish, Lepomis megalotis and rock bass, Ambloplites rupestris).

\subsubsection{Black Basses}

Artificial structures were used by black bass equally or more than the high quality natural reference sites during the day. Artificial structures contained significantly more black bass and juvenile black bass than high and low quality natural sites in 2002 (p < 0.001) (Figure 10). High and low quality natural sites were not different in total black bass and juvenile black bass abundance in 2002. Average catch per sample date of black bass on artificial structures was 18 black bass (18 of which were juveniles); high quality natural was 10 black bass ( 9 of which were juveniles); and low quality natural was 6 black bass (5 of which were juveniles).

Greater use of artificial structures during the day by black basses was not as apparent during the 2003 sampling as during the 2002 sampling (Figure 10). The greatest number of black bass, and furthermore juvenile black bass, were collected on artificial structures (Table 3). However, total catches of black bass were much less in 2003 than in 2002. The average catch of black bass per sample date among all sites in 2002 was 33 fish (32 of which were juveniles) in comparison to 17 fish in 2003 (13 of which were juveniles). As a result, in 2003 black bass and juvenile black bass habitat 
selection was inconclusive due to the low catch rates and high variability and these data showed no significant difference in habitat selection between artificial structures, high quality natural and low quality natural sites.

At night, artificial structures contained significantly more black bass than high and low quality natural reference areas in 2003 ( $\mathrm{p}<0.001)$ (Figure 10). More black bass were collected at night with collections at all sites combined to average 27 fish per sample date (21 of which were juveniles) at night versus 17 fish (13 of which were juveniles) during day sampling. Only artificial structure use by black bass and juvenile black bass was greater at night in comparison to day samples $(\mathrm{p}<0.001)$. Natural reference sites (high and low quality) were not different in black bass and juvenile black bass abundance between day and night sampling. High quality natural site collections had on average 16 black bass at night (16 of which were juveniles) versus 7 black bass during the day (5 of which were juveniles) (Table 3). Low quality natural sites had 4 black bass at night ( 3 of which were juveniles) in comparison to 6 black bass during the day (4 of which were juveniles).

The black bass group consisted of spotted bass and smallmouth bass. Spotted bass and smallmouth bass are nearly equally abundant in the river; however, spotted bass were slightly more abundant in 2002 than smallmouth bass, and smallmouth bass were slightly more abundant than spotted bass in 2003 (Tables 5, 6 \& 7).

\subsubsection{Sunfishes}

Sunfishes show the greatest level of selection for artificial structures versus high and low quality natural reference sites over any other group of fish (Figure 11). Artificial structures had significantly more sunfish and juvenile sunfish than did high and low quality natural sites during both the 2002 and 2003 sampling seasons ( $<$ 0.001).

The use of artificial structures by sunfish increased at night in 2003. Artificial structures housed significantly more sunfish than natural reference areas, and there was no difference between high and low quality natural reference sites $(\mathrm{p}<0.0001)$. We collected more sunfish and juvenile sunfish at night than during day sampling. Artificial 
structures showed the greatest increase in night catches versus day catches for sunfish and juvenile sunfish $(\mathrm{p}<0.001)$. The average sunfish catch per sample date on artificial structures was 46 fish (41 of which were juveniles) at night versus 17 sunfish (14 of which were juveniles) during day collections (Table 3). High and low quality natural reference sites also housed significantly more sunfish and juvenile sunfish at night (high quality natural sites $\mathrm{p}<0.001$, low quality natural sites $\mathrm{p}<0.01$ ). High quality natural site collections had 23 sunfish (22 of which were juveniles) at night in comparison to 4 sunfish (3 of which were juveniles) during the day. Low quality natural sites had the fewest sunfish where at night the average catch was 9 sunfish (7 of which were juveniles) versus 5 sunfish during the day (3 of which were juveniles).

Sunfish species found in the Kanawha River included bluegill, green sunfish, longear sunfish, and rock bass. Longear sunfish are by far the most abundant sunfish species in the Kanawha River often comprising half or more of the overall sunfish abundance (Tables 5, 6 \& 7). Bluegill sunfish were more abundant than green sunfish in 2002, but bluegill abundance decreased in 2003. Green sunfish populations remained relatively constant between 2002 and 2003. Interestingly green sunfish were the only Centrarchidae fish to decrease in abundance at night versus during the day.

\subsection{Adult Seasonal Sampling}

Sampling of sites aimed to collect adult fish was conducted in addition to point abundance sampling. Data was collected once per season in 2003 (March, June, August, October). The resulting patterns in fish selection of habitat (artificial structure versus high and low quality natural reference areas) were similar to point abundance sampling. Species richness was greatest on artificial structures and least in low quality natural sites. Cyprinidae and Catostomidae species were similar in abundance between high quality natural sites and artificial structures, but greater than in low quality natural sites. Black bass and sunfish prefer artificial structures significantly more than natural reference areas. 
Adult collections showed some variation in fish use per sampling period (Figure 12, Table 4). Black bass and sunfish were collected in March, were nearly absent in June, and become more abundant in August and October, with October being the highest. This pattern occurs with all site types (artificial structure and high and low quality natural reference sites), but is most prominent on artificial structures. Cyprinidae abundance is greatest in June and August samples and decreases into October. The greatest diversity of Cyprinidae species occurs in August. The abundance of Cyprinidae catch is equal between artificial structures and high quality reference sites, but their abundance is higher than other sites on the Finger Dyke 1 structure and the Finger Dyke 1 high quality natural reference site. Catostomidae have the highest abundance in June with some movement into artificial structures in October indicating that although there was not a significant difference between high quality natural reference sites and artificial structures within the juvenile sampling regime examining all sample dates, artificial structures may serve as important habitat for this group during the fall months. 
Species not included within Catostomidae, Centrarchidae, and Cyprinidae also show some differentiation in habitat use with seasonal sampling. Freshwater drum were most abundant in October, but were found most in low quality natural reference sites. Gizzard shad abundance did not vary among sites, but were most abundant during the June sampling period and nearly disappearing during the remainder of collections. Sauger had the highest abundance in June but did not appear to select for artificial structures more than high quality natural reference sites. Logperch had the highest collections in August when high numbers were taken from artificial structures.

Several species were collected in adult sampling that were not captured during juvenile point abundance sampling (Table 8). In October we collected the only paddlefish (Polyodon spathula) (411 mm) seen during this study, collected at the Zipper Dyke high quality reference area. Not far from there, also in October, we collected an American brook lamprey (Lampetra appendix) (collected only once during point abundance sampling) at the high quality natural site for Finger Dyke 1. Other new collections include silver chub (Macrhybopsis storeriana), collected only at the low quality reference site for Finger Dyke 4, telescope shiner (Notropis telescopis) collected at the high quality natural reference site for Finger Dyke 1, and a white crappie (Poxmoxis annularis) collected on Finger Dyke 2 artificial structure.

\subsection{Individual Artificial Structure Performance}

Each of the five sets of structure varied some in their performance as indexed by capture rates of fish. Finger Dyke 4 was typically the worst performer in both 2002 and 2003 on all accounts except for 2003 day sampling where it was found to have higher diversity than other structures (Figure 13 -18). Seemingly the most important structures for fish were the Zipper Dykes and Finger Dyke 2. These two structures housed the greatest number of fish and the highest diversities most of the time (Figure 14). These structures were used most by Centrarchidae species over any other group. The Zipper Dykes were somewhat less important in terms of measured fish attraction in 2003 versus 
2002 and may be due to apparent heavy sedimentation within that structure thus reducing its overall submerged surface area.

Moderate fish abundance performers included Finger Dyke 3 and Finger Dyke 1. Finger Dyke 3 was not important during the day but its use became significant at night when Centrarchidae species, both black bass and sunfish, moved into it $(\mathrm{p}<0.05)$ (Figure 17 \& 18). For sunfish, Finger Dyke 2 and the Zipper Dykes remained most selected for at night over Finger Dyke 3; however, at night black bass selected the Finger Dyke 3 more than any other structure with Finger Dyke 2 not far behind.

Cyprinidae and Catostomidae species generally did not select for artificial structure type more than high quality natural reference sites. Catostomidae species held the pattern of no artificial structure being more important than any other although some preference was shown for Finger Dyke 1 (Figure 16). Cyprinidae species showed no difference between artificial structure types during the day, but moved into Finger Dyke 1 significantly at night $(\mathrm{p}<0.01)$ (Figure 15).

Water quality among sites did not differ significantly within any measure (temperature, dissolved oxygen, salinity, conductivity, specific conductivity, turbidity). The average measured water qualities collected for each date is listed in Table 9. The logged temperature data running from October 28, 2002 through March 17, 2004 did not vary among sites. The temperature information representing all sites is demonstrated in Figure 19.

\subsection{Artificial Structures Provide Low Velocity Zones}

Artificial structures in place within the littoral zone provide areas of lower velocity in comparison to similar areas without artificial structures. In order to quantify this, we measured water velocity at each site. Three velocity transects were made at each of 15 sites measuring flow once every meter along a transect perpendicular from shore to six meters using a Marsh-McBirney flow meter. This occurred on 12 dates from May to August 2003. 
The three different categories of sites: artificial structures, and high and low quality natural reference areas had significantly different velocities within them ( $\mathrm{p}<$ 0.001). Results show artificial structures have the lowest velocities associated with them (Figure 20). For all structures, velocities remain extremely low (less than $0.05 \mathrm{~m} / \mathrm{s}$ ) for most of their length. Velocities begin to increase at five meters from shore, which for most sites corresponds to the end of the structure and velocities measured at six meters have the highest velocities and are closest to the main channel flow.

Natural reference areas had significantly higher velocities than artificial structures. High quality natural sites begin with velocities greater than the artificial structure sites and gently increase in velocities in a linear fashion until six meters from shore. The sixth meter velocities in high quality natural sites have a much higher velocity than the sixth meter measure on artificial structures indicating that structures are probably influencing velocity patterns after the end point. The greatest velocities were measured in the low quality natural sites. Velocities began higher than in high quality natural sites or artificial structures and increased nearly exponentially with distance away from shore. Measured points furthest from shore had extremely high velocities with some highest measures often from 0.5 to $0.9 \mathrm{~m} / \mathrm{s}$. Artificial structures maximum velocities were between 0.04 and $0.08 \mathrm{~m} / \mathrm{s}$ and high quality natural sites maximum velocities were between 0.1 and $0.3 \mathrm{~m} / \mathrm{s}$.

\subsection{River Discharge and Habitat Use}

River discharges in 2002 were lower than average and 2003 flows were higher than average for the Kanawha River (Figure 21). The flows can be considered to be two extremes with the 2002 flows being extremely low during the dry year and conversely the 2003 season characterized high flows with major spikes that on occasion pushed the Kanawha River near flood stage. Catches in 2002 were on average 2.5 times greater than catches in 2003. The difference in catch between 2002 and 2003 is greatest within Cyprinidae species where 2002 catches were 3 to 6 times greater than catches in 2003. 
Observations from the September 5, 2003 day sampling event suggest stress in fish populations during heavy flows. On that date water temperature within the sample sites dropped $3^{\circ}$ Celsius within 24 hours and was the quickest, largest drop in temperature throughout the entire year. This occurred together with a high flow event and river discharge increasing 30,000 cfs within a five day period (Figure 22). Fish collected showed signs of heavy stress, including heavy slime coats and limp bodies unresisting to handling upon collection. In addition we had highest overall catch than any other sample date for 2003 day sampling and greatest on artificial structures more than any other site.

The 2002 sampling season had lower flows and fish did not respond to the river flow significantly during the entire sampling season (Figure 22). The average total catch (total catch per site) was correlated most with water temperature $(\mathrm{p}=0.0007)$ in comparison to river flow $(\mathrm{p}=0.83)$. As water temperature increased the average catch decreased. River flow was not correlated with the average catch between sample sites (artificial structure, high and low quality natural reference sites) $(p>0.06)$.

Conversely, in 2003 average catch during both day and night sampling events (artificial structure and high and low quality natural reference sites combined) was highly correlated with river flow $(p<0.0001)$ and not with river temperature $(p=0.29)$. The average fish catch increased with higher flows in all sites as fish moved into littoral zones seeking protecting from the swift main channel. Previously we found artificial structures to have the lowest river flows associated with them, low quality natural reference sites to have the highest flows, and high quality natural reference sites between. As a result, artificial structures were utilized by fish during higher flows for velocity shelter as the average catch increased with higher river flow (day $: \mathrm{p}=0.02$, night $: \mathrm{p}=0.09$ ). The average species diversity within artificial structures increased in relation to higher river flow as well (day $: p=0.0008$, night $: \mathrm{p}=0.07$ ). Average catch was not significantly correlated with river flow within the high quality natural reference (day $: \mathrm{p}=0.32$, night : $\mathrm{p}=0.72$ ) or low quality natural reference (day $: \mathrm{p}=0.23$, night $: \mathrm{p}=0.74$ ). Species diversity within high quality natural reference sites increased with higher flow (day $: \mathrm{p}=$ $0.03)$, but did not increase within the low quality reference sites $(p=0.13)$. At night species diversity within high quality natural reference sites did not increase with higher flows $(\mathrm{p}=0.35)$. 


\section{Section Four: Discussion}

\subsection{Fish Use Artificial Structures as a Source of Habitat}

Fish did use artificial structures as a source of habitat in the Kanawha River. The use of artificial structures by fish is similar to the use of high quality natural references but greater than low quality natural references during the day. At night the use of artificial structures was greater and significantly more fish used artificial structures than high and low quality natural references. Species richness was equal to or greater on artificial structures in comparison to high quality natural reference sites. As a result, artificial structures do provide a useable habitat for fish when compared to near-by natural reference habitats. The use of artificial structures by fish groups varies where fish species may use the artificial habitats for different reasons (cover and forage).

Cyprinidae species showed little selection for artificial structures during the day where they were collected equally between artificial structures and high quality natural reference sites but more than in low quality natural reference sites. At night the numbers of Cyprinidae species increased; however, their use continued to not vary between artificial structures and high quality natural reference sites. Based on this, Cyprinidae do use some form of cover but do not benefit from the greater complexity provided by the rock structures. At night, as their schools dissemble, Cyprinidae species used inshore areas as shelter but continued to select equally for artificial structure and high quality natural references.

Catostomidae species habitat use was not different between artificial structure and high quality natural reference sites during the day. The number of Catostomidae species collected at night was much greater than during the day since their forage activity increases at night (Emery 1973) and in their selection for habitat they were collected in artificial structure and high quality natural reference equally, but the actual average catches were somewhat greater in high quality natural references. The artificial structure 
sites were likely too shallow for the large Catostomidae species to find any real advantage to their use and of all sites the high quality natural references provided the best habitat for their needs.

The greatest use of artificial structures occurred within the Centrarchidae species (black bass and sunfish). Most Centrarchidae species collected were juveniles. Centrarchidae species were collected more on artificial structures than in natural reference areas in nearly all cases. The selection for artificial structure was greater among sunfish species than among black bass species. Centrarchidae species were collected in higher numbers at night than during the day where artificial structures had even greater numbers of fish than did natural reference sites. Centrarchidae species likely benefited from the high level of cover provided by the structure material, greater forage attraction in the forms of crayfish or macroinvertebrates, and lower water velocity. Since Centrarchidae species collected were most often juveniles, these smaller fish are using the artificial structures as a source of protection from predation and river conditions during periods of higher risk such as darkness and higher river flows. Although artificial structures overall attracted higher numbers of Centrarchidae species over natural references, the greatest use between artificial structure types was associated with the highest level of heterogeneity (greatest amount of structure per area) and the lowest measured velocities within a site (Zipper Dyke and Finger Dyke 2). As a result, juvenile Centrarchidae show a real use of artificial structure habitats and likely benefit as a result. Since use is most common among the juveniles, the artificial structures may increase the potential for young Centrarchidae species survival.

The results generated from this project match similar projects examining the effect of cover and protection from river flow together on fish abundance and habitat selection. Poizant and Pont (1996) found that fish use dykes as a source of habitat and higher fish abundance (especially juvenile Lepomis spp.) in association with lower flows in the Lower Rhône River, France. Fish abundance, especially juveniles and species of Centrarchidae, is greatest with high levels of cover (habitat projects, vegetation, snags and woody debris) and lowest level of river flow (Poizant and Pont 1996, Johnson and Jennings 1998, Freeman et al. 2001, Langler and Smith 2001). However, some argue that river flow, and the protection there of, is a greater determinate of juvenile 
recruitment than cover and flow combined. Fish abundance in flow protection areas was greater during periods of higher velocity (Freeman et al. 2001, Chavonec et al. 2002, Humphries et al. 2002, Pretty et al. 2003). In addition juvenile survival and recruitment was lowest during high flows thus indicating the need for habitat heterogeneity in riverine systems as a way to subdue resulting juvenile mortality during elevated flows (Freeman et al. 2001, Grift et al. 2003). Conversely, Li et al. (1984) found dykes and natural reference areas in Oregon not different in terms of larval fish abundance; however, the natural reference zones and dykes each had low flow associated thus the effect of flow protection eliminated.

\subsubsection{River Flow and Artificial Structures}

The water velocity generated from river flows was lowest within artificial structures and highest in low quality natural reference sites. We collected more fish on artificial structures during periods of higher river flow than during periods of low river flow. In large channelized river systems where flow protection is minimal, fish move into littoral zones during periods of high discharge. Since artificial structures are zones of low velocity, fish use them as a source of cover from swift moving water in the main channel. These low velocity areas may be most important to smaller and younger fish susceptible to displacement during high flow events.

Temperature and river flow are linked within regulated river systems. High flow events are often coupled with a decrease in water temperature making it difficult to separate the effects of river flow and temperature on the resulting fish community (Freeman et al. 2001, Nunn et al. 2003). Nunn et al. (2003) hypothesized that river flow and water temperature are intertwined such that during periods of low flows water temperature determines fish abundance and conversely during periods of high flow, river flow determines fish abundance. Our results support the Nunn et al. (2003) hypothesis. During the 2002 sampling season, river flow was abnormally low compared to the long time average for that river. During that season we had higher fish collections, especially juvenile Centrarchidae, in comparison to the 2003 season and average catch was 
correlated most with water temperature. Conversely, the 2003 season was characterized by higher than average flows and lower than average catches in comparison to the 2002 season, and furthermore fish collections were most correlated with river flow.

\subsubsection{Guidelines Set Forth for Artificial Structures}

Steimle and Zetlin (2000), as discussed within the introduction, have outlined a series of guidelines serving to steer the implementation of artificial structures as a source of fish habitat in both marine and freshwater aquatic systems. The findings of this study show our artificial structures fitting well into their guidelines. Steimle and Zetlin (2000) suggest artificial structure projects should act as corridors between habitat types, here a corridor between the main channel and littoral zones. Artificial structure should also result in an increase in cover and may vary depending on factors including time of year, river flow, time of day, and size. In 2002 fish abundance was highest later in the sampling season (September and October), therefore artificial structures may appeal to fish needs in the fall. Higher river flow increased the use of artificial structures in 2003, night observations were greater than day observations, and juvenile Centrarchidae had the highest abundance in association with reduced flows and higher habitat complexity provided by the structures.

Artificial structures encouraged species and organismal diversity. Fish species richness was higher on artificial structures than in natural reference sites in 2002 and at night in 2003 (low catch rates did not show a change in species richness during day 2003 collections). In addition, the rock structures created a high level of attachment surface and interstitial spaces between rocks were likely utilized by organisms such as algae and invertebrates. The diversity of habitat available at the artificial structure sites may have contributed to the greater species richness generally observed there.

Artificial structures decrease predation and increase forage and spawning in order to increase survival and subsequent recruitment. Predation decreases with the availability of cover (Lehtinen et al. 1997) and since small juvenile Centrarchidae fish are highly susceptible to predation, artificial structures may serve as protection against predation as 
evidenced by changes in day and night use of structures by juvenile fishes. We have no real evidence of the use of artificial structures for spawning grounds. Juvenile Centrarchidae fishes feed on invertebrates, zooplankton, and some small fishes and artificial structures likely provide greater amounts of these forage types (Emery 1973, Jenkins 1993).

In addition to benefiting fish populations, artificial structures can benefit anglers. These structures can be accessed and used as fishing areas. Centrarchidae species (black bass and sunfish) are the most abundant fish species within artificial structures and serve as popular game species. The use of artificial structures by game species increases the value of these sites in terms of potential angler success rates in addition to aiding the local game fish stock.

The Kanawha River's original habitat consisted of boulders and shoals creating a naturally heterogeneous environment. Since artificial structures create habitat heterogeneity that is used by fish they help to replace natural river habitats lost during the channelization process.

In conclusion, artificial structures provide viable habitats for fish in comparison to natural habitats. The use of artificial structures is greater at night. In the case of family Centrarchidae artificial structures provide better habitats than natural areas. In comparison to natural reference areas, artificial structures may provide more stable, longterm habitats than that provided by deposited woody debris and over-hanging vegetation in high and low quality natural areas. The selection for habitat type (artificial structure and high and low quality natural habitats) is likely based most on its ability to provide protection from river flows, cover from predation and greater forage.

\subsection{Implications for Management}

Several considerations should be made when designing either habitat enhancement evaluations of fish use or in the design of the enhancement project itself. Below we list some considerations that should be incorporated into similar projects. 
It is important to consider the target species (Thompson 2002). This study demonstrates that artificial structures have the ability to provide habitat heterogeneity that can be utilized by fish as a source of cover and forage. The use of these structures was greatest among juvenile species of family Centrarchidae. This concurs with past studies finding, basses and more so sunfish, to prefer heterogeneous habitats consisting of rock and vegetation over homogeneous habitats (Gannon et al. 1985, Bohnsack et al. 1991, Poizat and Pont 1996). Structures did not appear to have an impact on Cyprinidae or Catostomidae species.

Diel fish assessment should be considered when designing an artificial habitat assessment plan. Within this study we have included both day and night sampling of the study sites. Without night observations, the calculated impacts of artificial structures would have been significantly less substantial showing that in many cases the structures were equally as important as natural sites consisting of woody debris and low lying trees. Incorporating both day and night fish sampling in the assessment of fish populations may be advantageous especially in the case of littoral zone use as many species move into littoral zones at night (Emery 1973, Sanders 1992). Many studies using only day sampling have minimal numbers and find it difficult to make as sound of conclusions as night studies thus including both night and day may provide an accurate view of fish populations while encouraging more accurate and directed management (Sanders 1992, Johnson and Covich 2000).

River flow played a major role in fish collections throughout this study. If fish production is to be increased it may be necessary, in addition to creating areas of higher habitat heterogeneity, to regulate river flows in a way that is sustainable to fish populations and during critical periods for early life stages in particular. Regulation of river flows, such as dampening large changes in discharge, is most important during critical juvenile fish periods (in this study from July through October) (Freeman et al. 2001, Humphries et al. 2002). In the current state of declining fisheries, it is becoming essential to regulate water flows in a way that is sustainable for local aquatic life (Lucas and Marmulla 2000, Freeman et al. 2001, Humphries et al. 2002). 
Artificial structures used in this study provided habitat heterogeneity that was used by fish. Artificial habitat enhancement projects will be most successful if a few considerations are included in their design.

First, natural components should be incorporated to make them attractive to a wider variety of species. The rock structures used here were most attractive to Centrarchidae species. If natural materials, such as aquatic vegetation and woody debris, are incorporated within these sites beyond rock alone it may attract a greater diversity of organisms beyond fish in addition providing habitats for a wider variety of fish species.

Second, enhancement projects should be designed with flow in mind. We have seen that river flow has a major impact on fish populations; therefore, structures should be able to provide low flow areas along with providing cover and forage. In addition, barge travel creates waves from passing vessels and could have an impact on fish similar to a high flow event and the level of barge travel should be considered. Passing barges and subsequent wave action on shore resuspends sediment and may increase sedimentation within structures while waves displace small fish (Hershfeld et al. 1986). Structures designed with river conditions in mind will likely be more successful.

Lastly, enhancement projects should be built for long-term use. Habitat enhancement projects in hopes of benefiting fish have a history of failure both structurally and in its ability to achieve the goals of the project (Frissell and Nawa 1992, Bassett 1994, Pratt 1994). Structures should be built to withstand river conditions in terms of flow, washout and sedimentation rates. In addition, since habitats are intended for long-term use as habitat enhancement, it is important to consider esthetic values in their design beyond strictly the needs goals. Structures should be incorporated into the natural river environment and decrease the unnatural appearance of the project.

Considering these guidelines in the further development of habitat enhancement projects in large rivers may help to achieve the greatest benefit in terms of fish populations. The original conditions of large rivers are unlikely to be restored. Including considerations in the design of these projects could heavily impact the ultimate success in terms of fish populations and ultimately the potential fish production of the river system as a whole. 


\section{Section Five: Summary}

1. Fish use artificial structures as a source of heterorganic habitats. Overall fish use of artificial structures was greatest at night in comparison to day collections.

2. Species diversity was greatest on artificial structures most of the time. When overall catches were low (2003 sampling season) diversity did not vary significantly between artificial structure and high quality reference sites.

3. Cyprinidae and Catostomidae species used artificial structures and high quality natural reference areas equally. The number of fish collected within Cyprinidae and Catostomidae was greater at night than during the day.

4. Juvenile family Centrarchidae species, black bass and sunfish, reaped the greatest benefit from artificial structures in comparison to high and low quality natural reference sites. Use of artificial structures over high quality reference sites was greatest at night. Centrarchidae fishes were associated with sites providing the highest level of heterogeneity and cover and the lowest flows.

5. River flow played a role in determining fish abundance. Fish abundance in 2002 was most related to temperature while fish abundance in 2003 was most related river flow conditions. In addition, river flow in 2002 was an extreme low in comparison to the mean flow for the river while the 2003 flows were an extreme high. 


\section{Section Six: $\quad$ Literature Cited}

Aarts, B.G.W, F.W.B. Van Den Brink, and P.H. Nienhuis. 2004. Habitat loss as the main cause of the slow recovery of fish faunas of regulated large rivers in Europe: The transversal floodplain gradient. River Research and Applications 20: 3-23.

Addair, J. 1944. The fishes of the Kanawha River system in West Virginia and some factors which influence their distribution. PhD Dissertation. Ohio State University.

Aggus. L.R. and G.V. Elliott. 1975. Effects of cover and food on year-class strength of largemouth bass. Black Bass Biology and Management, H. Clepper eds. Sport Fishing Institute: 317-322.

Albert, O.T. and O.A. Bergstad. 1993. Temporal and spatial variation in the species composition of trawl samples from a demersal fish community. Journal of Fish Biology 43 (Supplement A): 209-222.

Bassett, C.E. 1994. Use and evaluation of fish habitat structures in lakes of the eastern United States by the USDA Forest Service. Bulletin of Marine Science 55(2-3): 1137 - 1148 .

Beebe, J.T. 1996. Fluid speed variability and the importance to managing fish habitat in rivers. Regulated Rivers 12 (1): 63-79.

Bohnsack, J.A., D.L. Johnson, and R.F. Ambrose. 1991. Ecology of artificial reef habitats and fishes in Artificial Habitats for Marine and Freshwater Fisheries eds W. Seaman Jr. and L.M. Sprague. Academic Press, Inc. New York : 61 - 99.

Chovanec, A. F. Schiemer, H. Waidbacher, and R. Spolwind. 2002. Rehabilitation of a heavily modified river section of the Danaube in Vienna (Austria): Biological assessment of landscape linkages on different scales. International Rev. Hydrobiolgia 87 (2-3): 183-195.

Copp, G.H. and P. Jurajda. 1993. Do small riverine fish move inshore at night? Journal of Fish Biology 43 (Supplement A): 229-241.

Cowx, I.G. 2002. Analysis of threats to freshwater fish conservation: past and present challenges, in Conservation of Freshwater Fishes: Options for the Future, M.J. Collares-Pereira, M.M. Coelho and I.G. Cowx eds. Fishing New Books, .Blackwell, Oxford.

Emery, A.R. 1973. Preliminary comparisons of day and night habitats of freshwater fish in Ontario Lakes. Journal of Fisheries Research Board of Canada 30: 761-774. 
Etnier, D.A. and W.C. Starnes. 1993. The fishes of Tennessee. University of Tennessee Press, Knoxville, TN.

Freeman, M.C, Z.H. Bowen, K.D. Bovee, and E.R. Irwin. 2001. Flow and habitat effects on juvenile fish abundance in natural and altered flow regimes. Ecological Applications 11(1): 179-190.

Frissell, C.A. and R.K. Nawa. 1992. Incidence and causes of physical failure of artificial habitat structures in streams of Western Oregon and Washington. North American Journal of American Fisheries Society 12: 18 - 197.

Gannon. J.E., R.J. Danehy, J.W. Anderson, G. Merritt, and A.P. Bader. 1985. The ecology of natural shoals in Lake Ontario and their importance to artificial reef development in Artificial Reefs: Marine and Freshwater Applications, F.M. D’Itri eds. Lewis Publishers, Inc., New York, NY.

Giannico, G.R, and S. G. Hinch. 2003. The effect of wood and temperature on juvenile coho salmon winter movement, growth, density, and survival in side-channels. River research and applications 19: 219-231.

Great Kanawha Navigation Company. 1868. Report of the Great Kanawha Navigation Company. Perris \& Browne Printers, New York, NY.

Grift, R.E, A.D. Buijse, W.L.T. Van Densen, M.M. Machiels, J. Kranenbarg, J.G.P. Klein Breteler, and J.J.G.M. Backx. 2003. Suitable habitats for 0-group fish in rehabilitated floodplains along the lower River Rhine. River Research and Applications (in press).

Halls, A.S., D.D. Hoggarth, and K. Debnath. 2000. Impacts of hydraulic engineering on the dynamics and production potential of floodplain fish populations in Bangladesh: implications for management in Management and Ecology of River Fisheries, I.G. Cowx eds.:201 - 217.

Hershfeld, D.C., D.J. Orth, and L.A. Nielsen. 1986. Fish production in the Kanawha River and its relation to barge traffic. Pol. Arch Hydrobiol. 33(3/4): 295-303.

Hubacher, M. and W.D. Wintz. 2003. Reminiscences of Nitro - 1925 to 1934. Great Kanawha Valley Chemical Heritage, Symposium Proceedings. Monograph Series 6. May 3, 2003, Institute, West Virginia.

Humphries, P. L.G. Serafini, and A.J. King. 2002. River regulation and fish larvae: variation through space and time. Freshwater Biology 47: 1307-1331.

Jenkins, R.E. and N.M. Burkhead. 1993. Freshwater fishes of Virginia. American Fisheries Society, Bethesda, Maryland. 
Jobling, M. 1995. Environmental Biology of Fishes. Chapman \& Hall, New York.

Johnson, S.L. and A.P. Covich. 2000. The importance of night-time observations for determining habitat preferences of stream biota. Regulated Rivers: Research and Management. 16: 91-99.

Johnson, B.L. and C.A. Jennings. 1998. Habitat Association of small fishes around islands in the Upper Mississippi River. North American Journal of Fisheries Management 18: 327-336.

Kemp, E.L. 2000. The Great Kanawha Navigation. University of Pittsburgh Press, Pittsburgh, PA.

Kitchell, J.F., D.J. Stewart and D. Weininger. 1977. Applications of a bioenergetics model to yellow perch (Perca flavescens) and Walleye (Stizostedion vitreum vitreum). Fisheries Research Board Canada 34: 1922-1935.

Kuntz, R. 2003. US EPA Water Quality Data in support of enforcement actions against Kanawha Valley chemical industry discharges 1974-84. Great Kanawha Valley Chemical Heritage Symposium Proceedings May 3, 2003, Institute, West Virginia.

Langler, G.J. and C. Smith. 2001. Effects of habitat enhancement on 0-group fishes in a lowland river. Regulated Rivers : Research and Management 17: 677-686.

Li H.W., C.B. Schreck, R.A Tubb 1984. Comparison of habitats near spur dikes, continuous revetments, and natural banks for larval, juvenile, and adult fishes of the Willamette River. Water Resources Research Institute, Oregon State University.

Lehtinen, R.M., N.D. Mundahl, and J.C. Madejczyk. 1997. Autumn use of woody snags by fishes in backwater and channel border habitats of a large river. Environmental Biology of Fishes 49: 7-19.

Letcher, B.H., J.A. Rice, L.B. Crowder, and F.P. Binkowski. 1997. Size- and speciesdependent variability in consumption and growth rates of larvae and juveniles of three freshwater fishes. Canadian Journal of Fisheries and Aquatic Science 54: 405-414.

Lobb, M.D. III and D.J. Orth. 1991. Habitat use by an assemblage of fish in a large warmwater stream. Transactions of the American Fisheries Society 120: 65-78.

Lucas, M.C. and G. Marmulla. 2000. An assessment of anthropogenic activities on and rehabilitation of fisheries: current state and future direction in Management and Ecology of River Fisheries, I.G. Cowx eds.:261 - 278. 
Madejczyk, J.C., N.D. Mundahl, and R. Lehtinen. 1998. Fish assemblages of natural and artificial habitats within the channel border of the Upper Mississippi River. 139(2): 296-310.

Magoulick, D.D. and R.M. Kobza. 2003. The role of refugia for fishes during drought: a review and synthesis. Freshwater Biology 48: 1186-1198.

Messinger. T. and D.B. Chambers. 2001. Fish Communities and their relation to environmental factors in the Kanawha River Basin, West Virginia and North Carolina, 1997-1998. Water Resources Investigations Report 01-4048, National Water Quality Assessment. USGS. Charleston, West Virginia.

Moring, J.R. and P.H. Nicholson. 1994. Evaluation of three types of artificial habitats for fishes in a freshwater pond in Maine, USA. Bulletin of Marine Science 55 (2-3): 1149-1159.

Muhar, S. 1996. Habitat improvement of Australian rivers with regard to different scales. Regulated Rivers: Research and Management 12: 471 - 482.

Nicholas, Y. and D.Pont. 1995. Importance of artificial backwaters for juvenile fish recruitment in a heavily regulated large river, the Lower-Rhone. Bull. Fr. Peche Piscic.: 337/338/339: 249-257.

Nunn, A.D., I.G. Cowx, P.A. Frear, and J.P. Harvey. 2003. Is water temperature an adequate predictor of recruitment success in cyprinid fish populations in lowland rivers?. Freshwater Biology 48: 579-588.

Odum, M.C. 1987. Distribution of larval fishes in the Winfield pool, Kanawha River, and direct impacts of commercial navigation traffic on larval fish survival. Thesis for Master of Science. Virginia Polytechnic Institute and State University, Blacksburg, Virginia.

Pardue, G.B. 1973. Production response of the bluegill sunfish, Lepomis macrochirus Rafinesque, to added attachment surface for fish-food organisms. Transactions of the American Fisheries Society (3): 622-626.

Personal Communication. February 2004. Kimberley Bacon, LRH. US Army Corp of Engineers, Huntington District.

Poizat G. and D. Pont. 1996. Multi-scale approach to species-habitat relationship: juvenile fish in a large river section. Freshwater Biology 36: 611-622.

Pratt, J.R. 1994. Artificial habitats and ecosystem restoration: managing for the future. Bulletin of Marine Science 55 (2-3): 268 - 275.

Pretty, J.L., S.S.C. Harrison, D.J. Shepherd, C. Smith, A.G. Hildrew, and R.D. Hey. 
2003. River rehabilitation and fish populations: assessing the benefit of instream structures. Journal of Applied Ecology 40: 251-265.

Prince, E.D. and O.E. Maughan. 1979. Attraction of Fishes to Artificial Tire Reefs in Smith Mountain Lake, Virginia. North Central Division American Fisheries Society Special Publication 6: 19-25.

Rider, S.J. and F.J. Margraf. 1998. Foraging characteristics of larval bluegill sunfish and larval longear sunfish in the Kanawha River, West Virginia. Journal of Freshwater Ecology 13(2): 221-228.

Robichaud-LeBlanc, K.A. and S. Courtenay. 1998. Distribution and growth of young-ofthe-year striped bass in the Miramichi River estuary, Gulf of St. Lawrence. Transactions of the American Fisheries Society 127:56-69.

Rountree, R.A. and K.W. Able. 1992. Foraging habits, growth, and temporal patterns of salt-marsh creek habitat use by young-of-year summer flounder in New Jersey. Transactions of the American Fisheries Society 121: 765-776.

Sanders, R.E. 1992. Day versus night electrofishing catches from near-shore waters of the Ohio and Muskingum Rivers. Ohio Journal of Science. 92(3): 51-59.

Savino J.F. and R.A. Stein. 1989. Behavior of fish predators and their prey: habitat choice between open water and dense vegetation. Environmental Biology of Fishes 24(4) 287- 293.

Scott, M.C. and P.L. Angermeier. 1998. Resource use by two sympatric black basses in impounded and riverine sections of the New River, Virginia. North American Journal of Fisheries Management 18(2): 221-233.

Scott, M.T. 1988. Larval fish abundance and habitat associations in backwaters and main channel borders of the Kanawha River. Thesis for Masters of Science. Virginia Polytechnic Institute and State University, Blacksburg Virginia.

Scott, M.T. and L.A. Nielsen. 1989. Young fish distribution in backwaters and main channel-borders of the Kanawha River, West Virginia. Journal of Fish Biology 35 (Supplement A): 21-27.

Sheehan, R.J. and J.L. Rasmussen. 1999. Large Rivers in Inland Fisheries Management in North America $2^{\text {nd }}$ edition eds. By C.C. Kohler and W.A. Hubert. American Fisheries Society, Bethesda Maryland : 529 - 557.

Skov, C. and S. Berg. 1999. Utilization of natural and artificial habitats of YOY pike in a biomanipulated lake. Hydrobiologia 408/409: 115-122.

Slavik, O. and L. Bartos. 2000. Seasonal and diel changes of young-of-the-year fish in 
the channelised stretch of the Vltava River (Bohemia, Czech Republic) in Management and Ecology of River Fisheries eds. I.G. Cowx. Hull International Fisheries Institute, University of Hull, UK : 101 - 113.

Stanford, J.A, J.V. Ward, W.J. Liss, C.A. Frissell, R.N. Williams, J.A. Lichatowich, and C.C. Coutant. 1996. A general protocol for restoration of regulated rivers.

Regulated Rivers: Research and Management 12: 391-413.

Steimle, F.W. and C.Zetlin. 2000. Reef habitats in the middle Atlantic Bight: Abundance, distribution, associated biological communities, and fishery resource use. Marine Fisheries Review 62(2): 24-42.

Sutphin, G.W. and R.A. Andre. 1991. Sternwheelers on the Great Kanawha River. West Virginia State Archives.

Takemon, Y. and K. Nakanishi. 1998. Reproductive success in female Neolamprologus mondabu (Cichlidae): influence of substrate types. Environmental Biology of Fishes 52: 261-269.

Thompson, D.M. 2002. Long-term effect of instream habitat-improvement structures on channel morphology along the Blackledge and Salmon Rivers, Connecticut, USA. Environmental Management 29(1): 250-265.

Walters, C. and J.F. Kitchell. 2001. Cultivation/depensation effects on juvenile survival and recruitment: implications for the theory of fishing. Canadian Journal of Fisheries and Aquatic Science 58: 39-50.

Walters, D.A., W.E. Lynch Jr., and D.L. Johnson. 1991. How depth and interstice size of artificial structures influence fish attraction. North American Journal of Fisheries Management 11: 319- 329.

Zar, J.H. 1999. Biostatistical Analysis, $4^{\text {th }}$ edition. Prentice Hall, Upper Saddle River, NJ. 


\section{Section Seven: Figures}




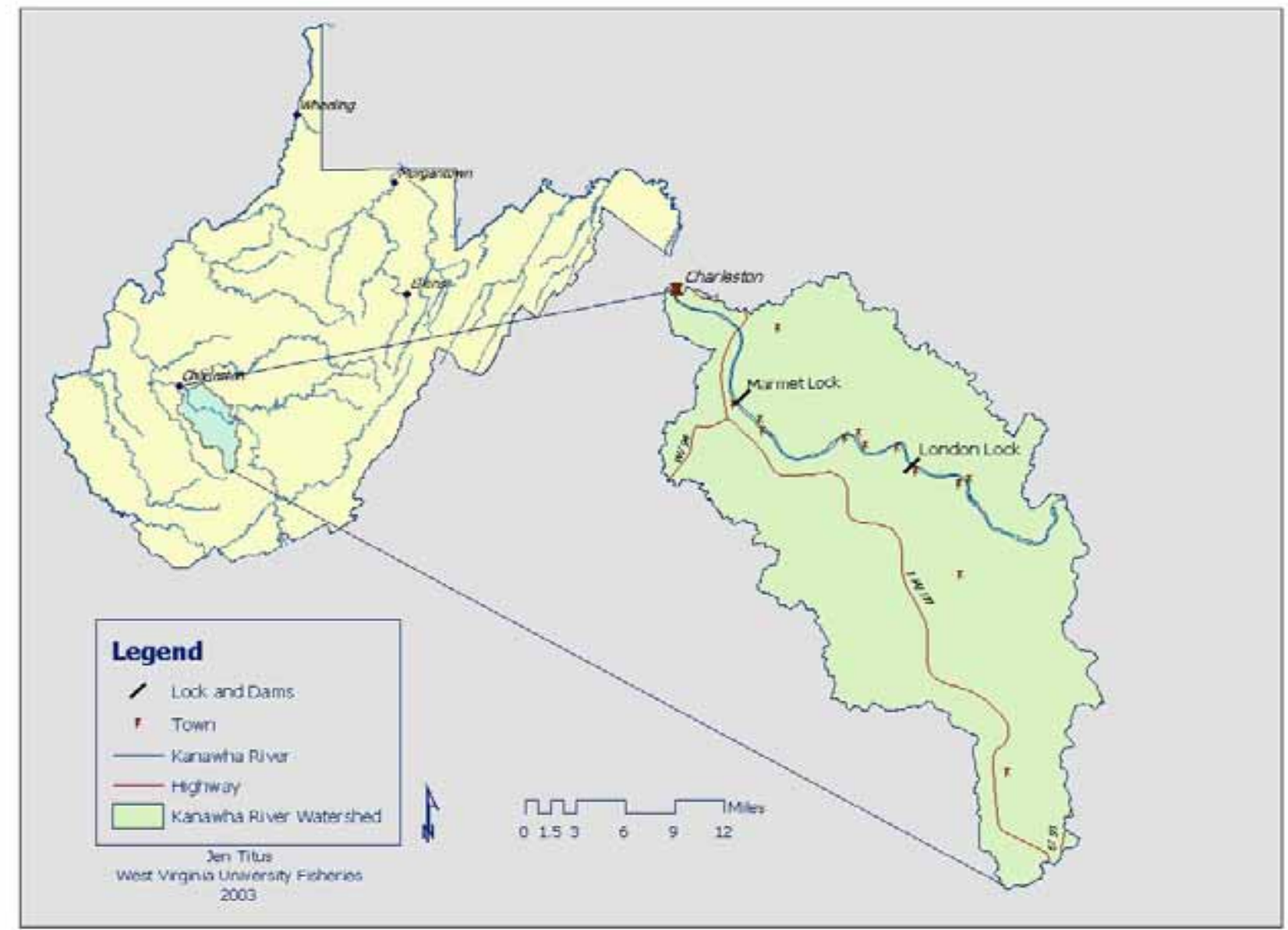

Figure 1 : The Kanawha River, West Virginia begins at the confluence of the New and Gauley Rivers at the southern most portion of the Kanawha River watershed and flows north until reaching the Ohio River, West Virginia. The Marmet Pool is located between the Marmet and London lock and dams upstream from the city of Charleston and is the second of three pools within the Kanawha River. 


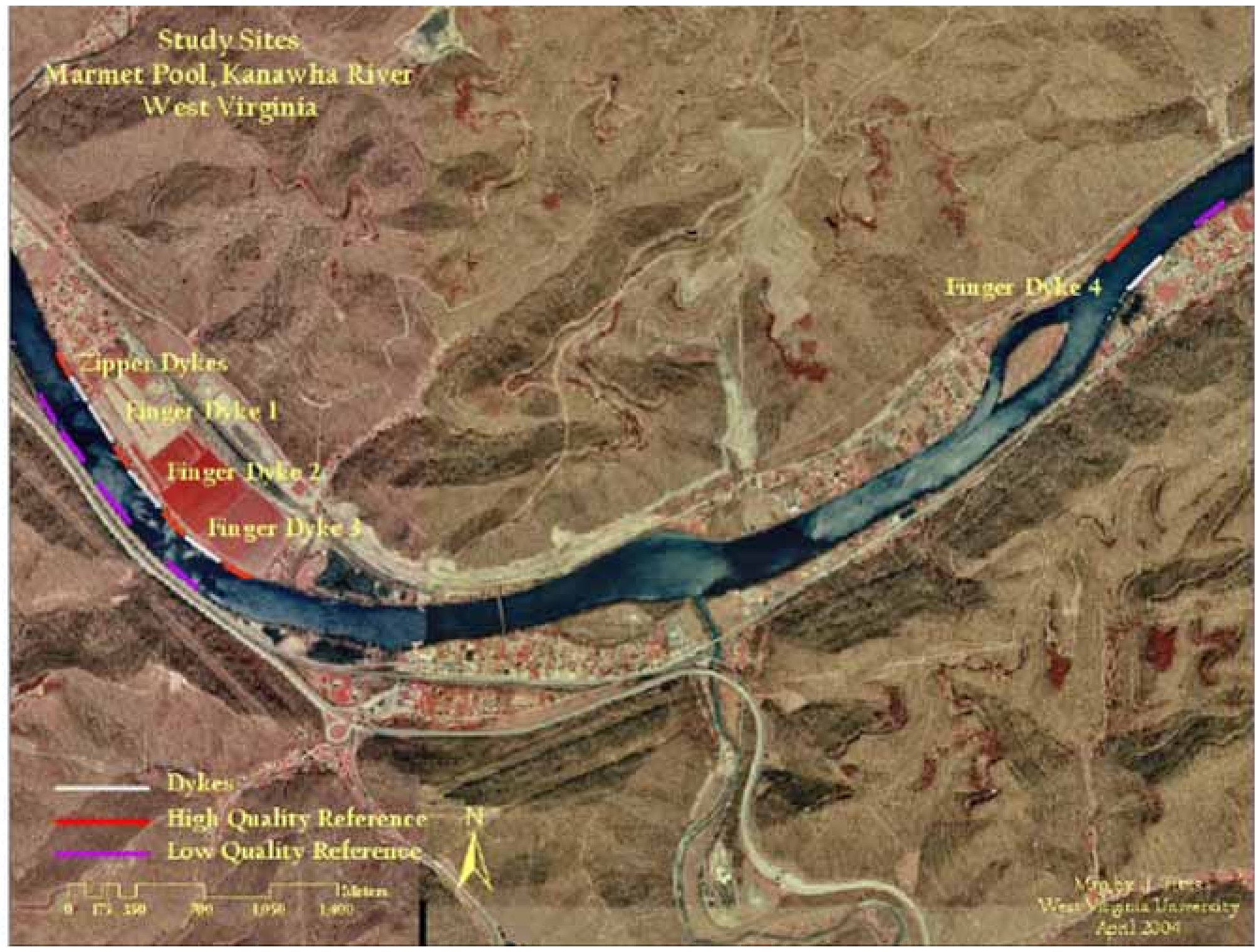

Figure 2 : Study Area within Marmet Pool, West Virginia 


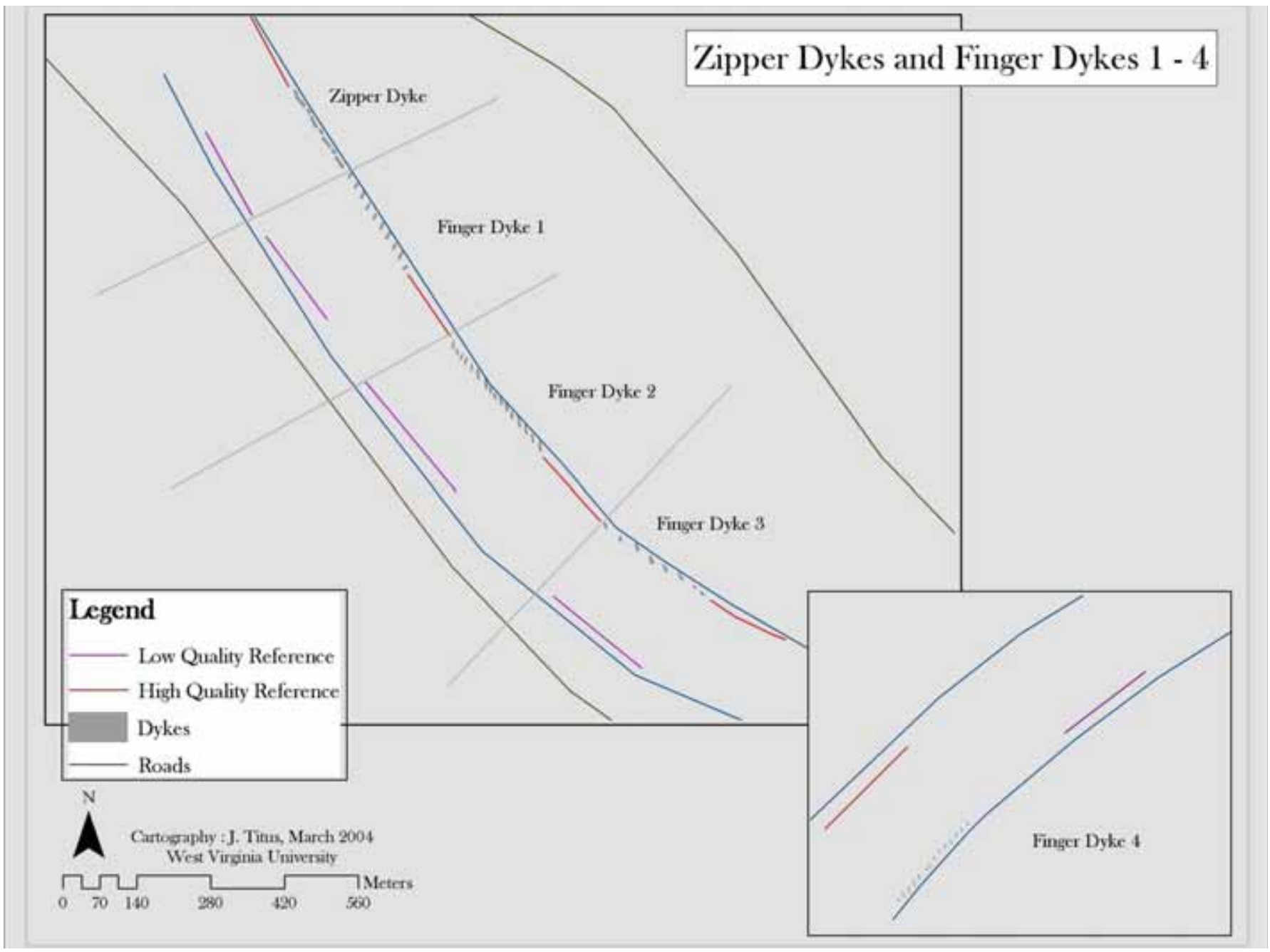

Figure 3 : Finger Dykes and Zipper Dyke and location of their associated high and low quality natural reference areas within the Kanawha River. Finger Dyke 4 resides upstream from the remaining dykes (see Figure 2). Notice the differences in dyke density between structure types. 


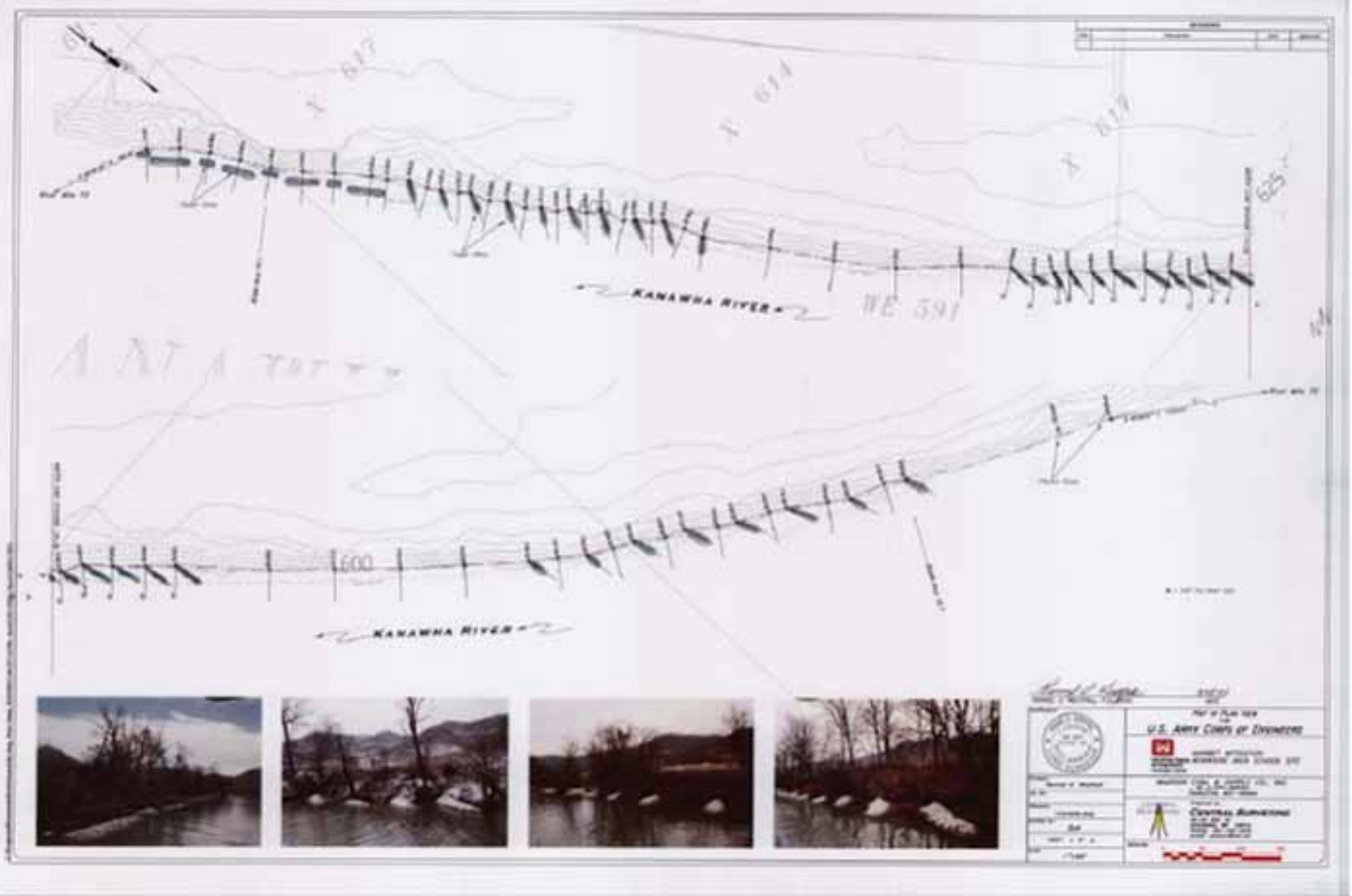

Figure 4 : Zipper Dyke and Finger Dyke 1 \& 2 (upper section) and Finger Dyke 2 \& Finger Dyke 3 (lower section) survey map. Notice change of scale from Figure 5. 


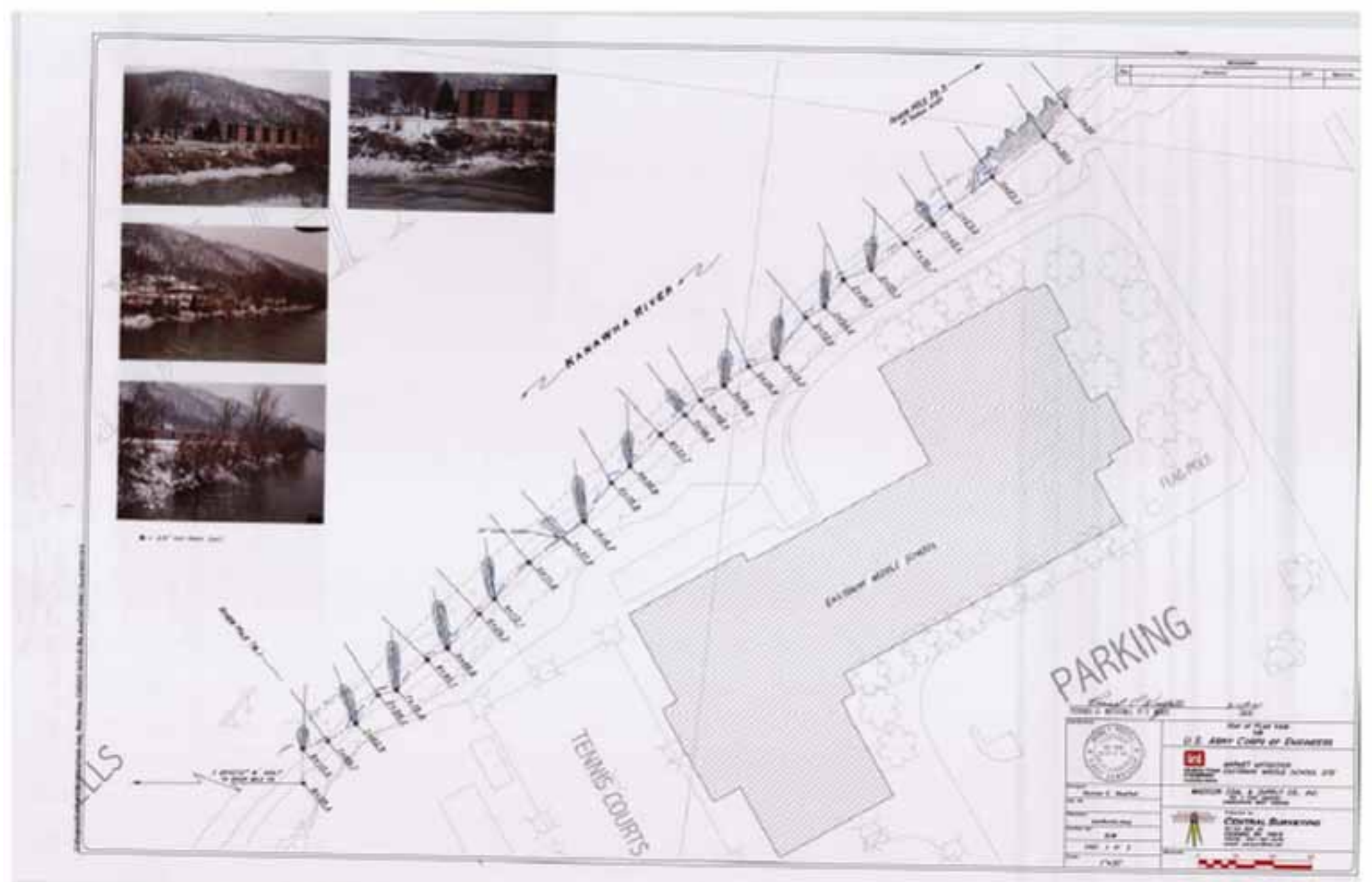

Figure 5 : Finger Dyke 4 survey map. Note change in scale from Figure 4. 

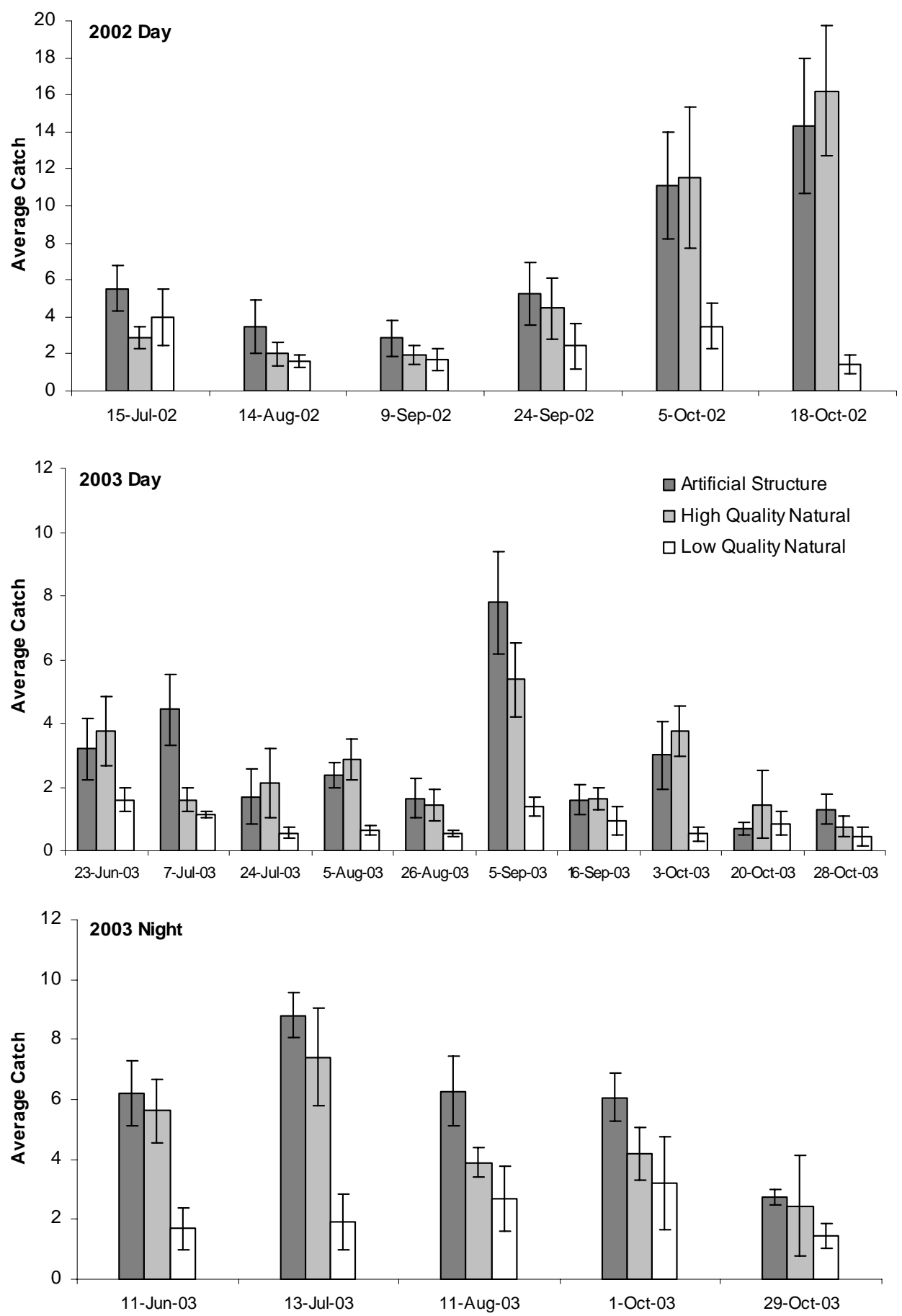

Figure 6 : Average total catch ( average ( total catch / effort ) among 5 sites combined ) for each sample date within each of artificial structure, high quality natural and low quality natural references sites in 2002 and 2003. Error bars represent 95\% confidence interval. Notice change of y-axis scale from 2002 Day to 2003 Day, 2003 Night. 

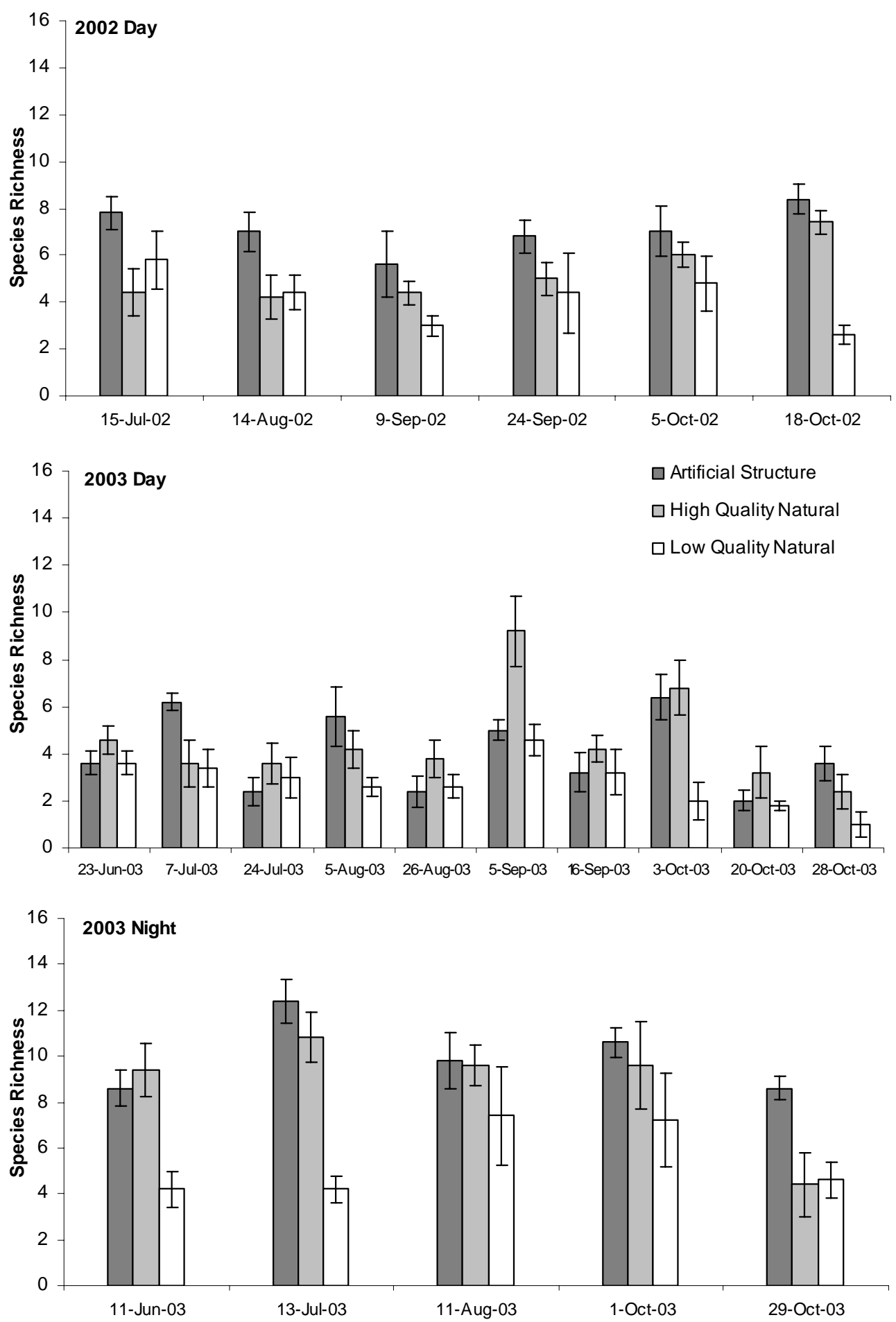

Figure 7 : Average species richness ( average species richness among 5 sites combined ) for each sample date within each of artificial structure, high quality natural and low quality natural references sites in 2002 and 2003. Error bars represent 95\% confidence interval. 

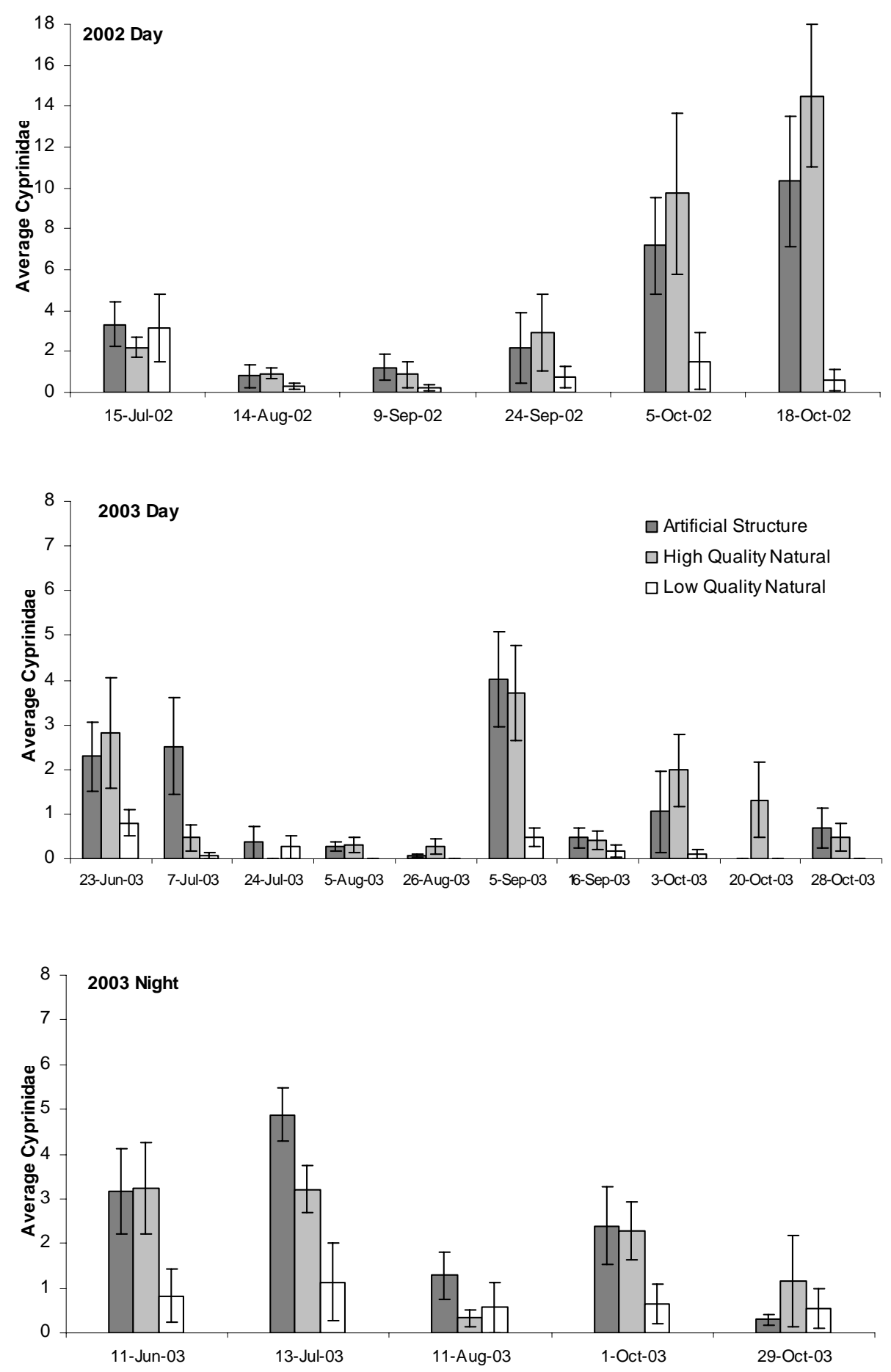

Figure 8 : Average family Cyprinidae ( average Cyprinidae catch (total / effort ) among 5 sites combined ) for each sample date within each of artificial structure, high quality natural and low quality natural reference sites in 2002 \& 2003. Error bars represent 95\% confidence intervals. Notice change of y-axis scale from 2002 Day to 2003 Day \& Night. 

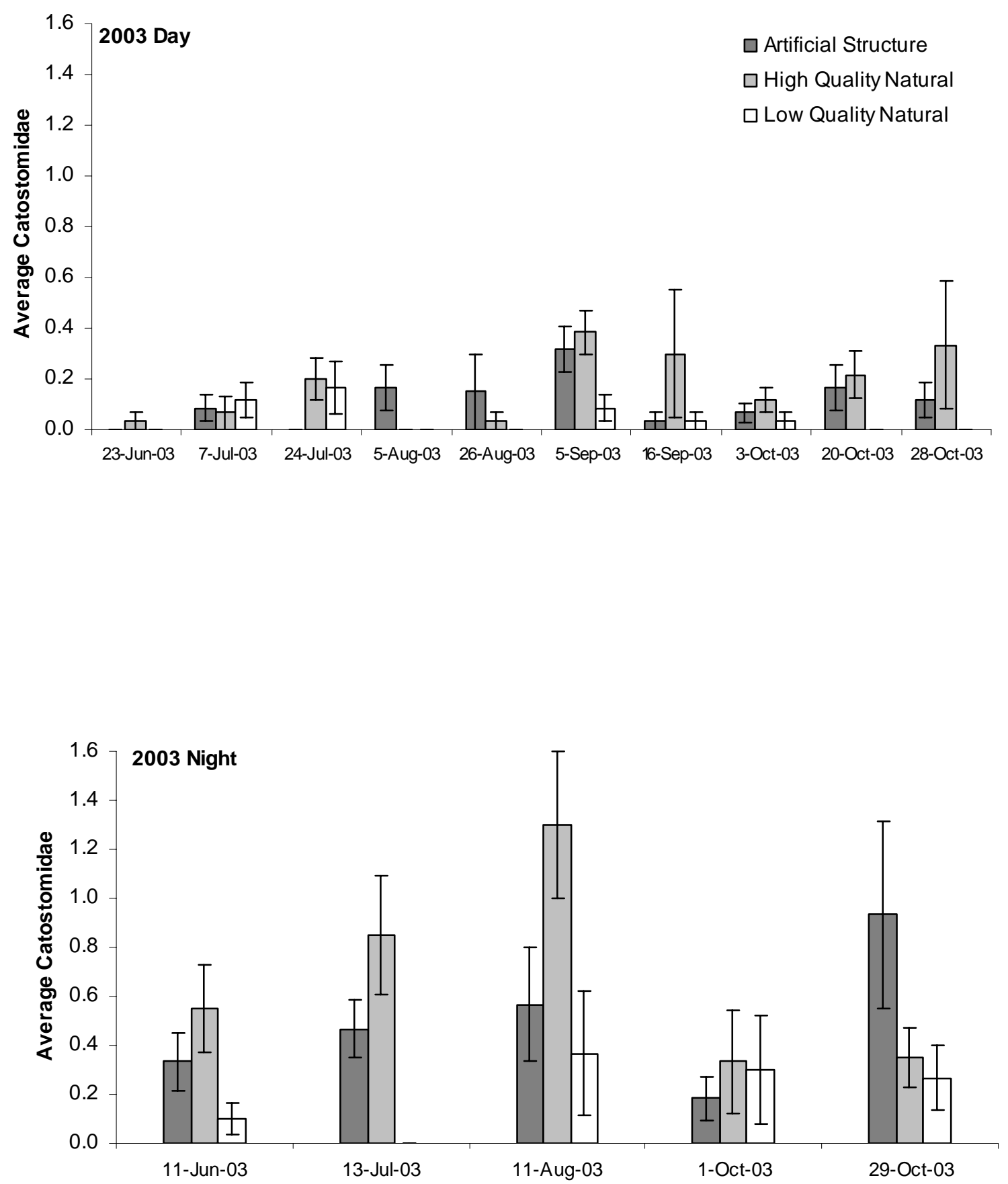

Figure 9 : Average family Catostomidae ( average Catostomidae catch (total / effort ) among 5 sites combined ) for each sample date within each of artificial structure, high quality natural and low quality natural references sites in 2003. Error bars represent 95\% confidence interval. 

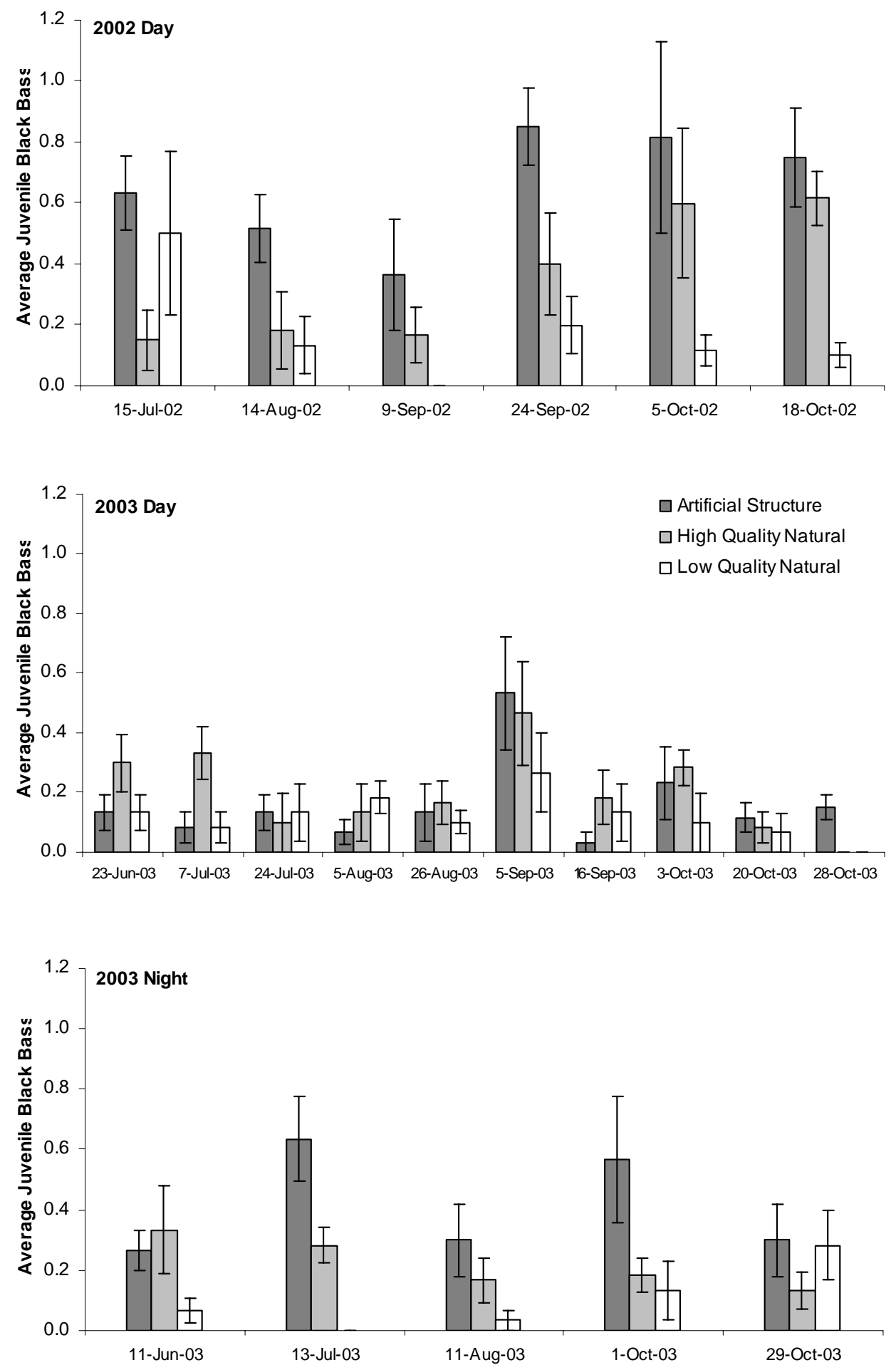

Figure 10 : Average juvenile black bass ( average black bass catch (total / effort ) among 5 sites combined ) for each sample date within each of artificial structure, high quality natural and low quality natural references sites in 2002 and 2003. Error bars represent 95\% confidence interval. 

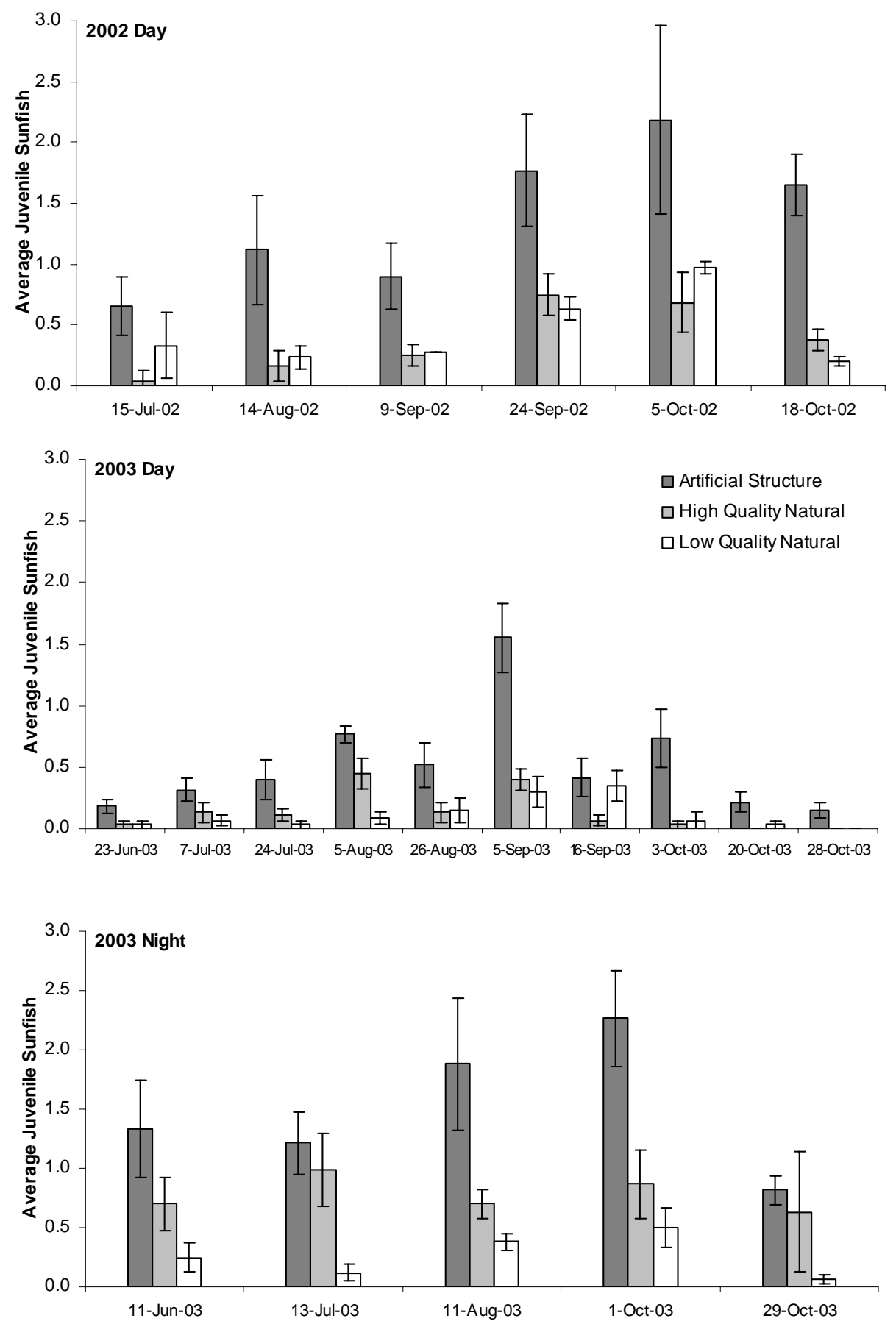

Figure 11.: Average juvenile sunfish ( average sunfish catch (total / effort ) among 5 sites combined ) for each sample date within each of artificial structure, high quality natural and low quality natural references sites in 2002 and 2003. Error bars represent 95\% confidence interval. 

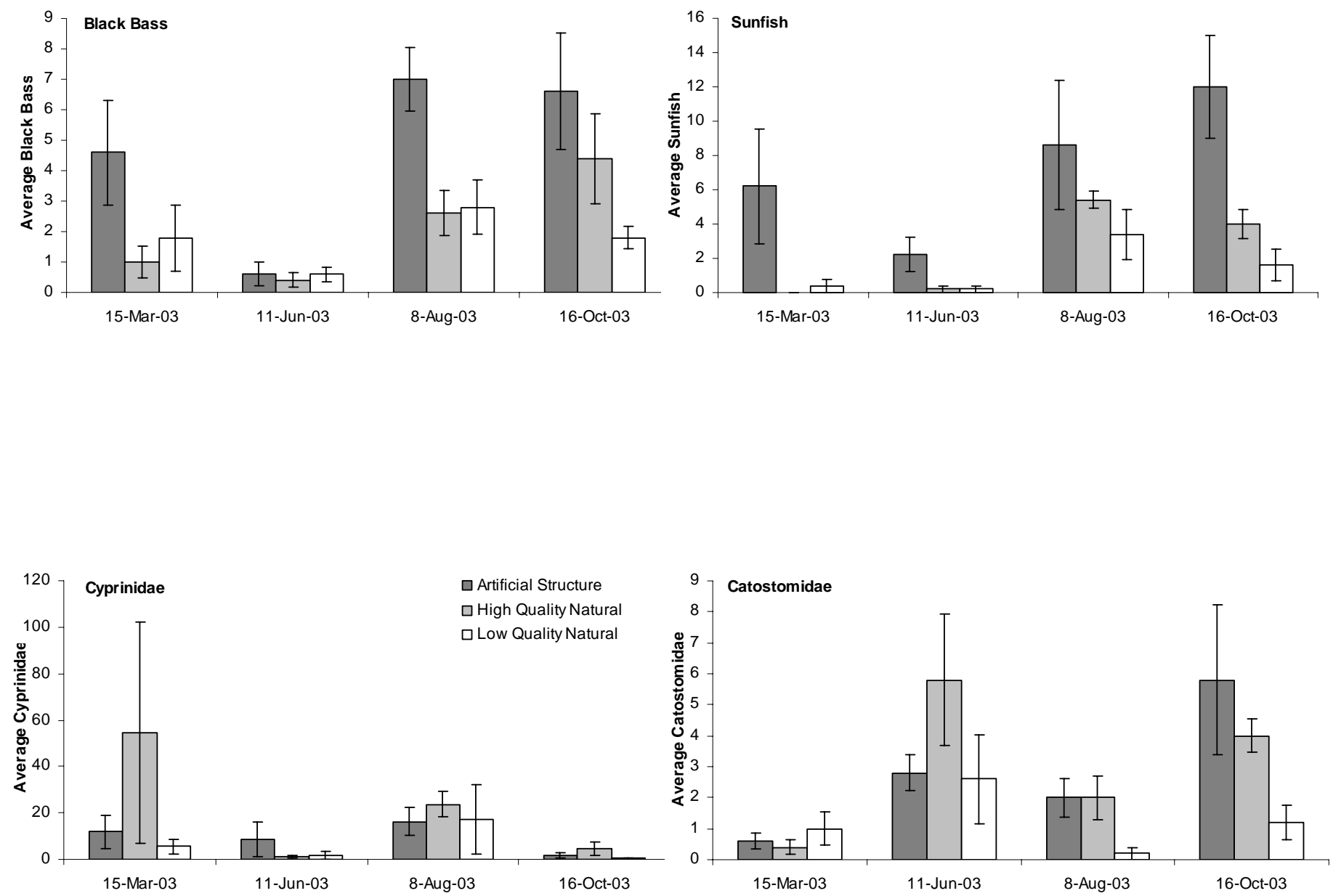

Figure 12 : Adult collection fish catches for each sample date. Average fish catch per adult sampling event for artificial structure, high quality natural reference, and low quality natural reference sites in 2003. Error bars represent 95\% confidence intervals. 

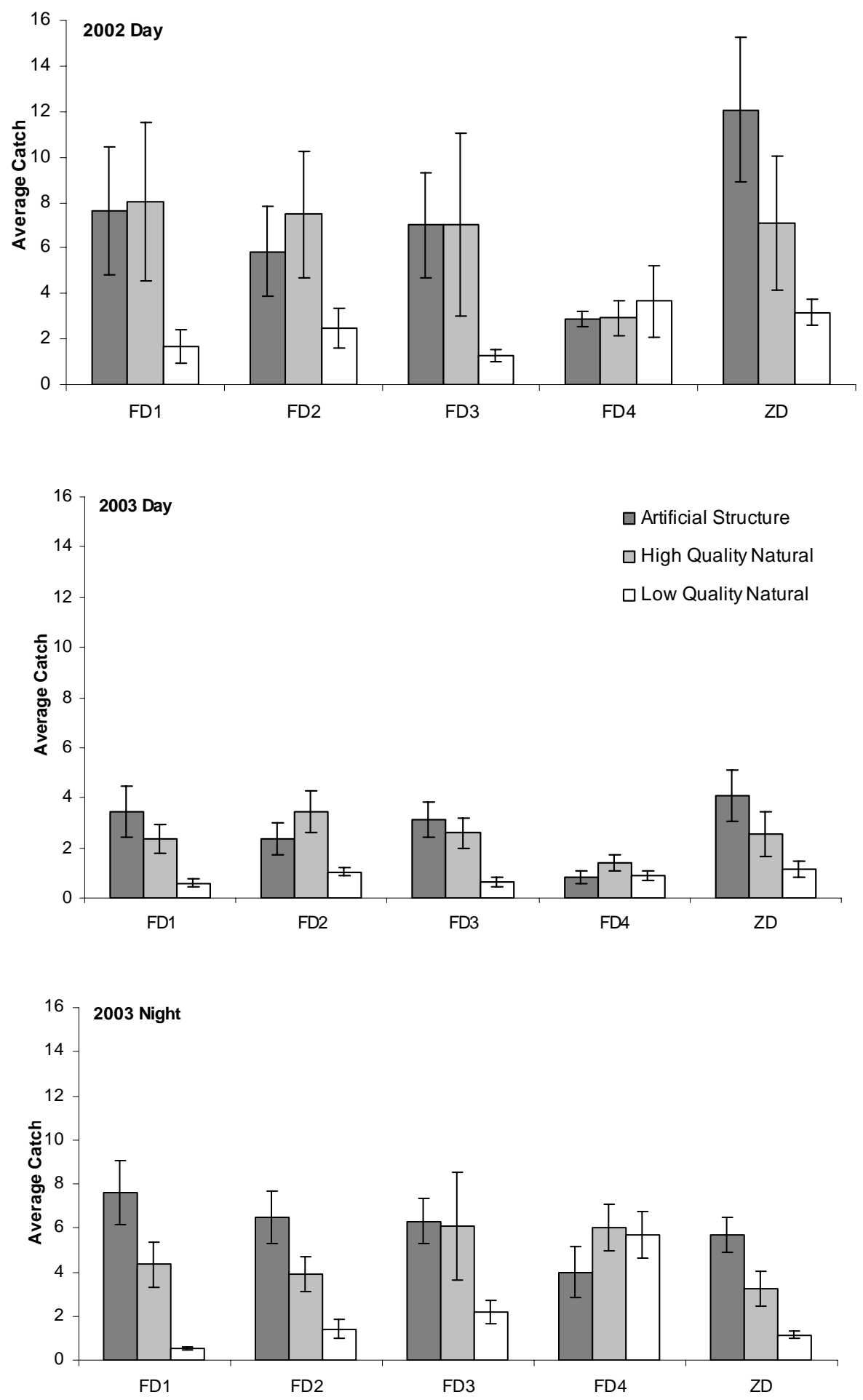

Figure 13 : Average total catch ( average ( total catch / effort ) among all sample dates combined ) within each structure type for artificial structure types and the associated natural reference areas in 2002 and 2003. Error bars represent $95 \%$ confidence intervals. 

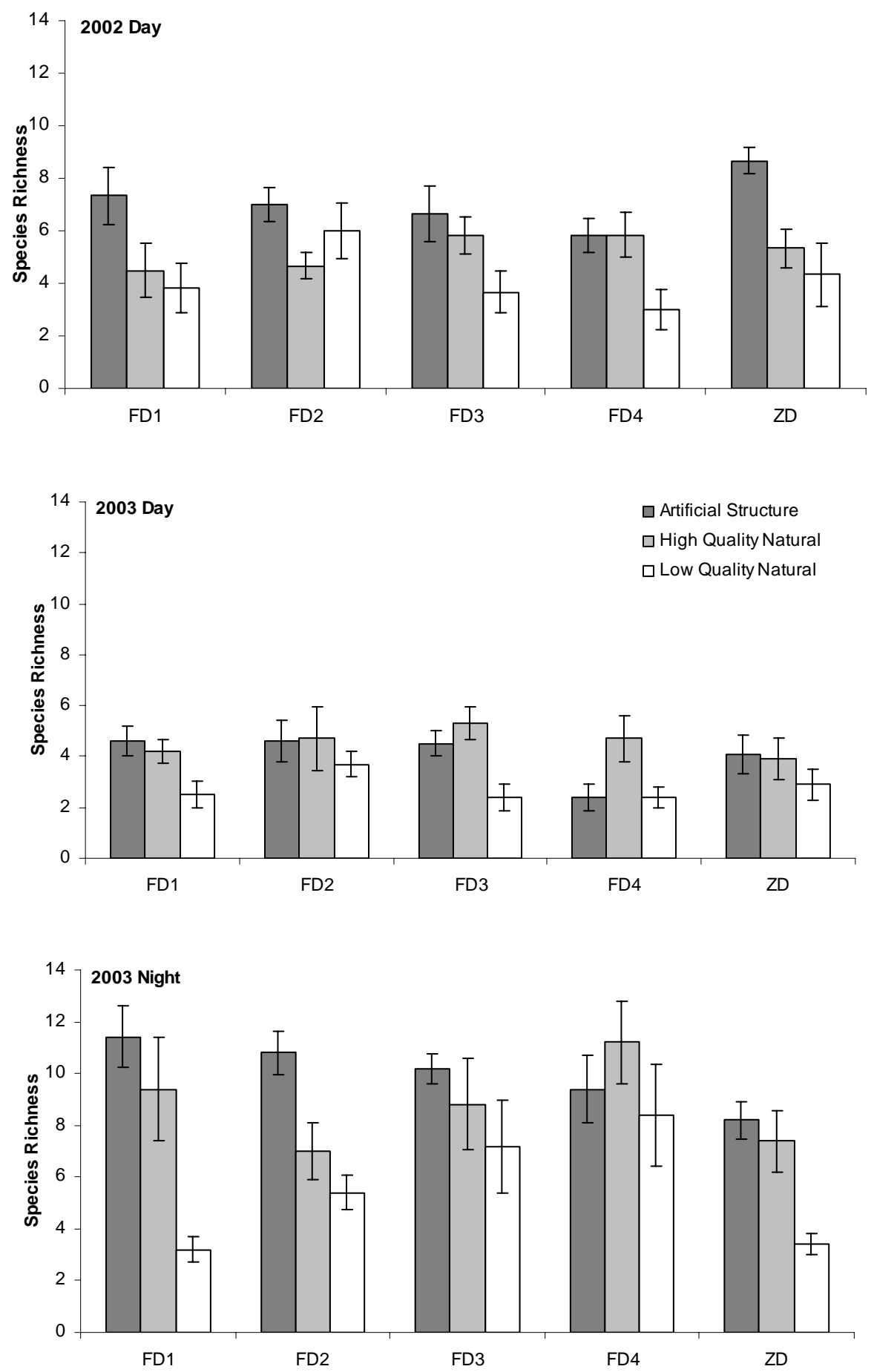

Figure 14 : Average species richness (species richness within a site per sample date) within each structure type for artificial structure types and the associated natural reference areas in 2002 and 2003 . Error bars represent $95 \%$ confidence intervals. 

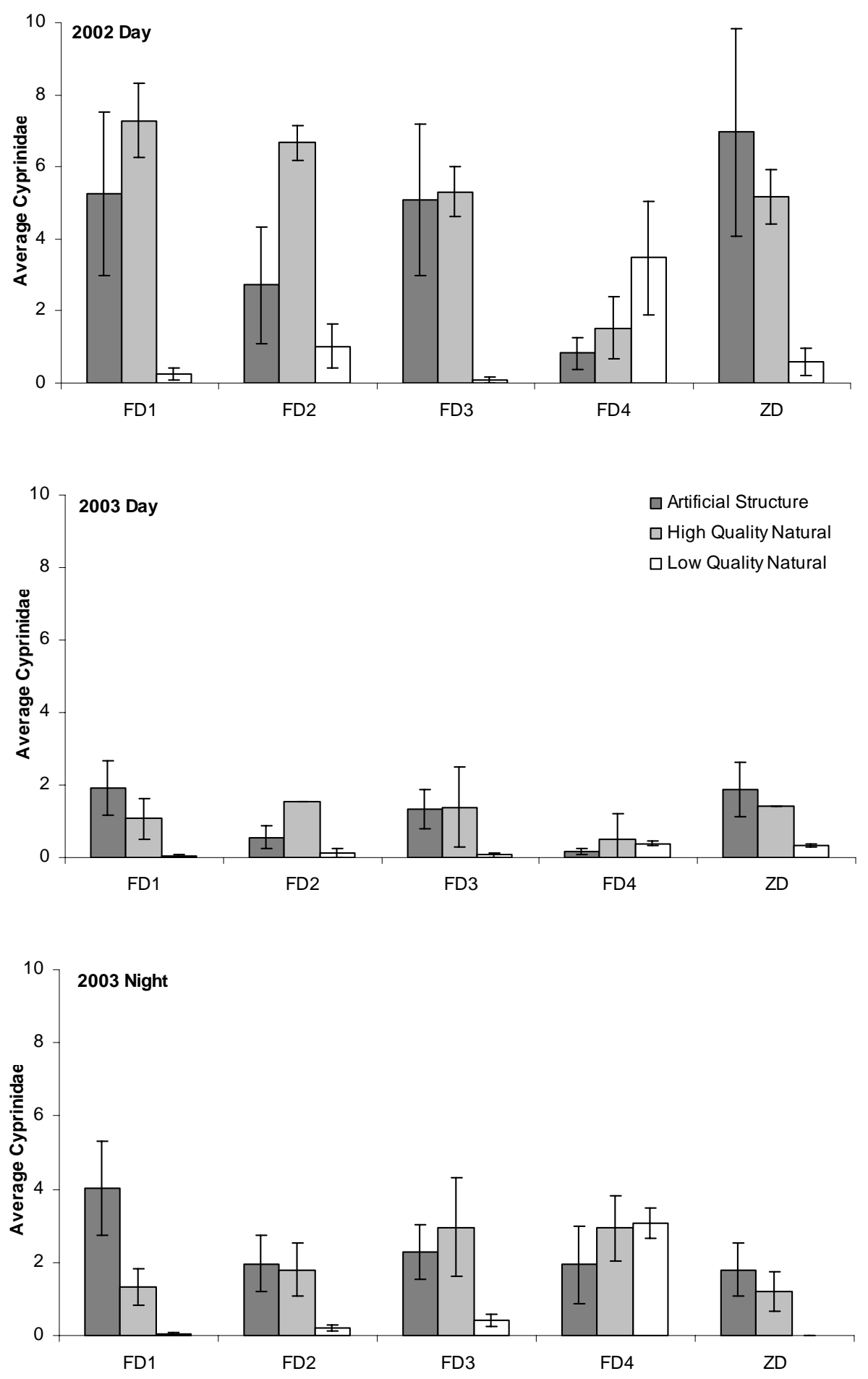

Figure 15 : Average Cyprinidae (average Cyprinidae within a site / sample date) within each structure type for artificial structure types and the associated natural reference areas in 2002 and 2003. Error bars represent $95 \%$ confidence intervals. 

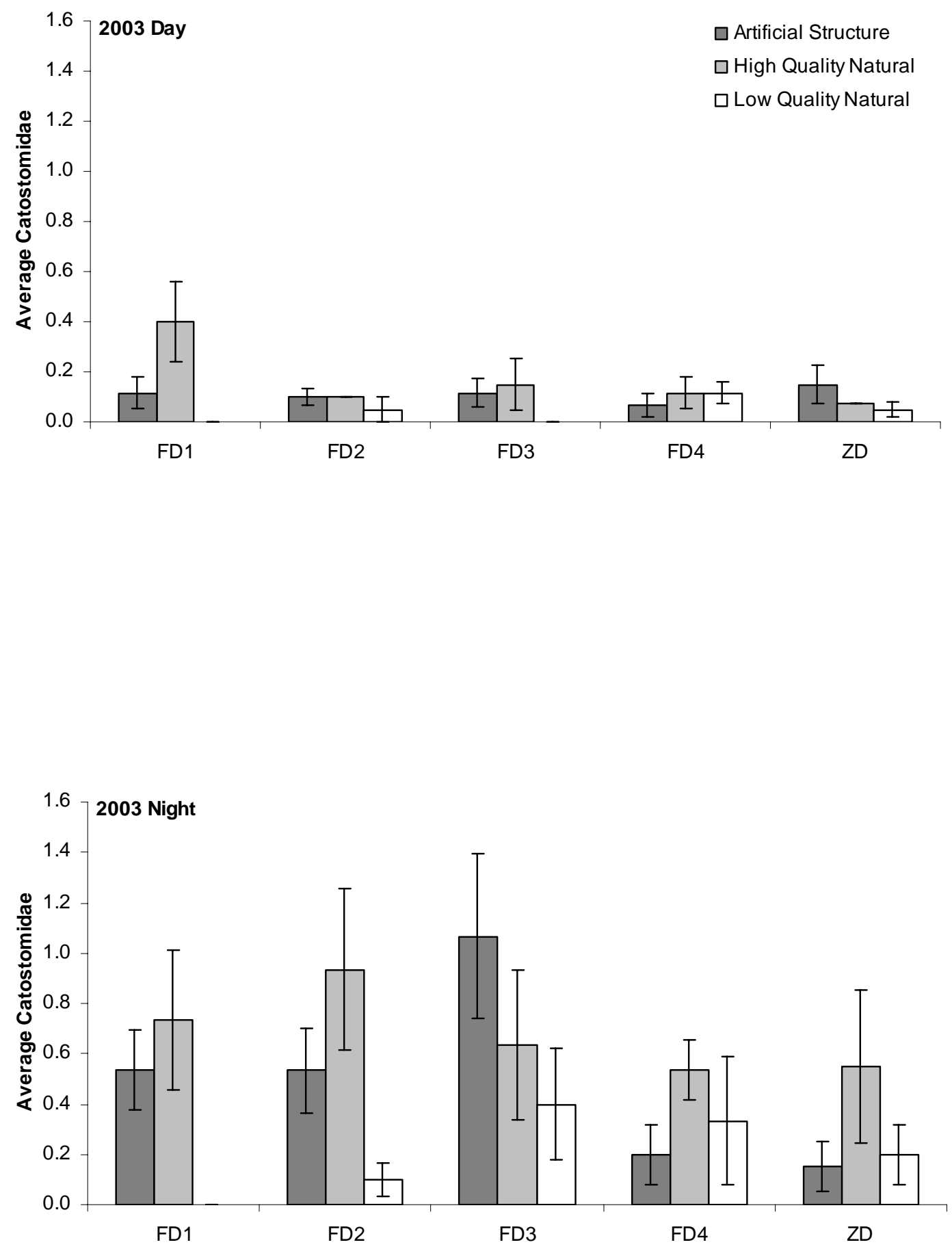

Figure 16 : Average Catostomidae (average Catostomidae within a site per sample date) within each structure type for artificial structure types and the associated natural reference areas in 2002 and 2003. Error bars represent $95 \%$ confidence intervals. 

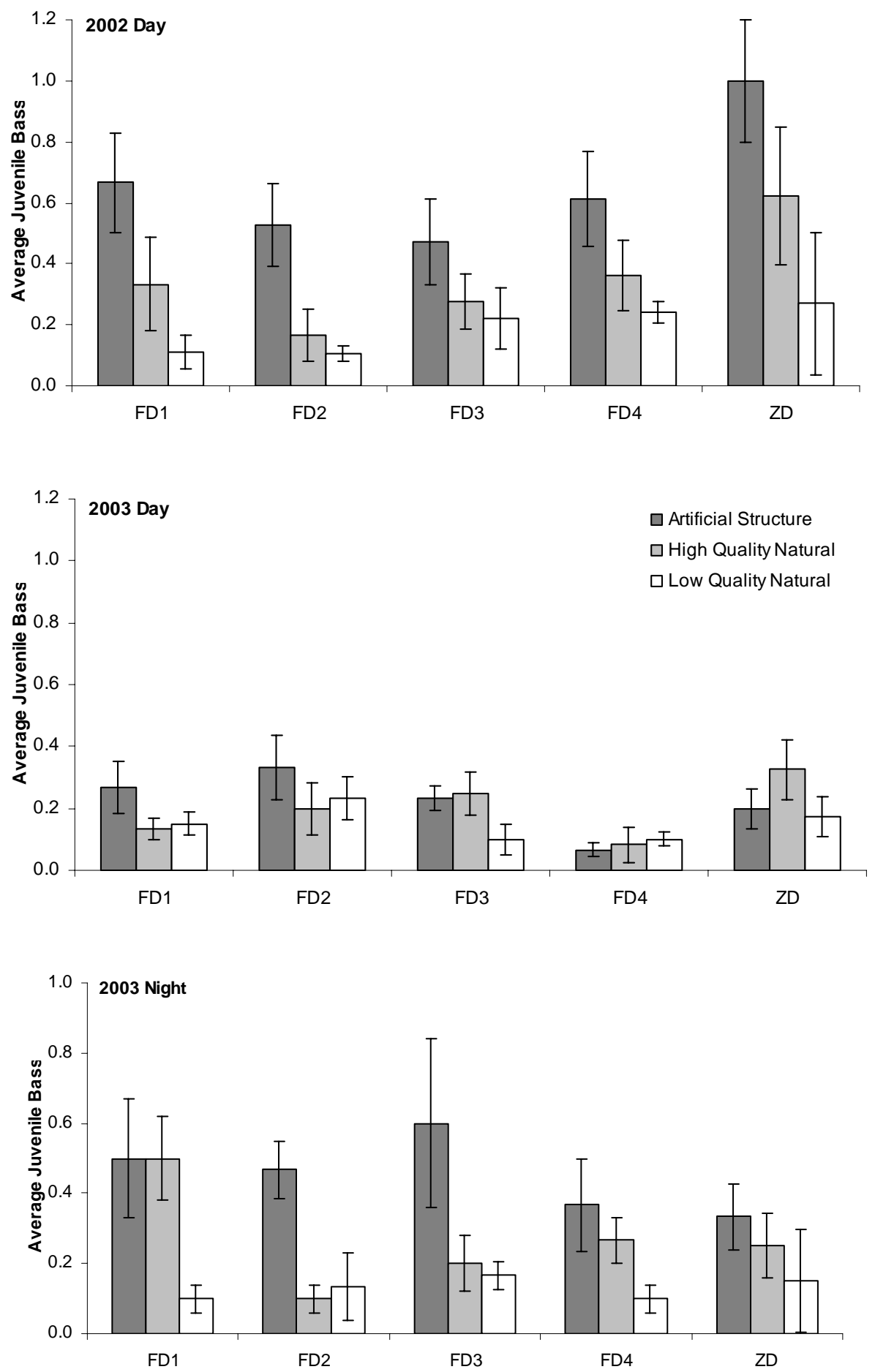

Figure 17 : Average juvenile black bass (average juvenile black bass within a site per sample date) within each structure type for artificial structure types and the associated natural reference areas in 2002 and 2003. Error bars represent 95\% confidence intervals. 

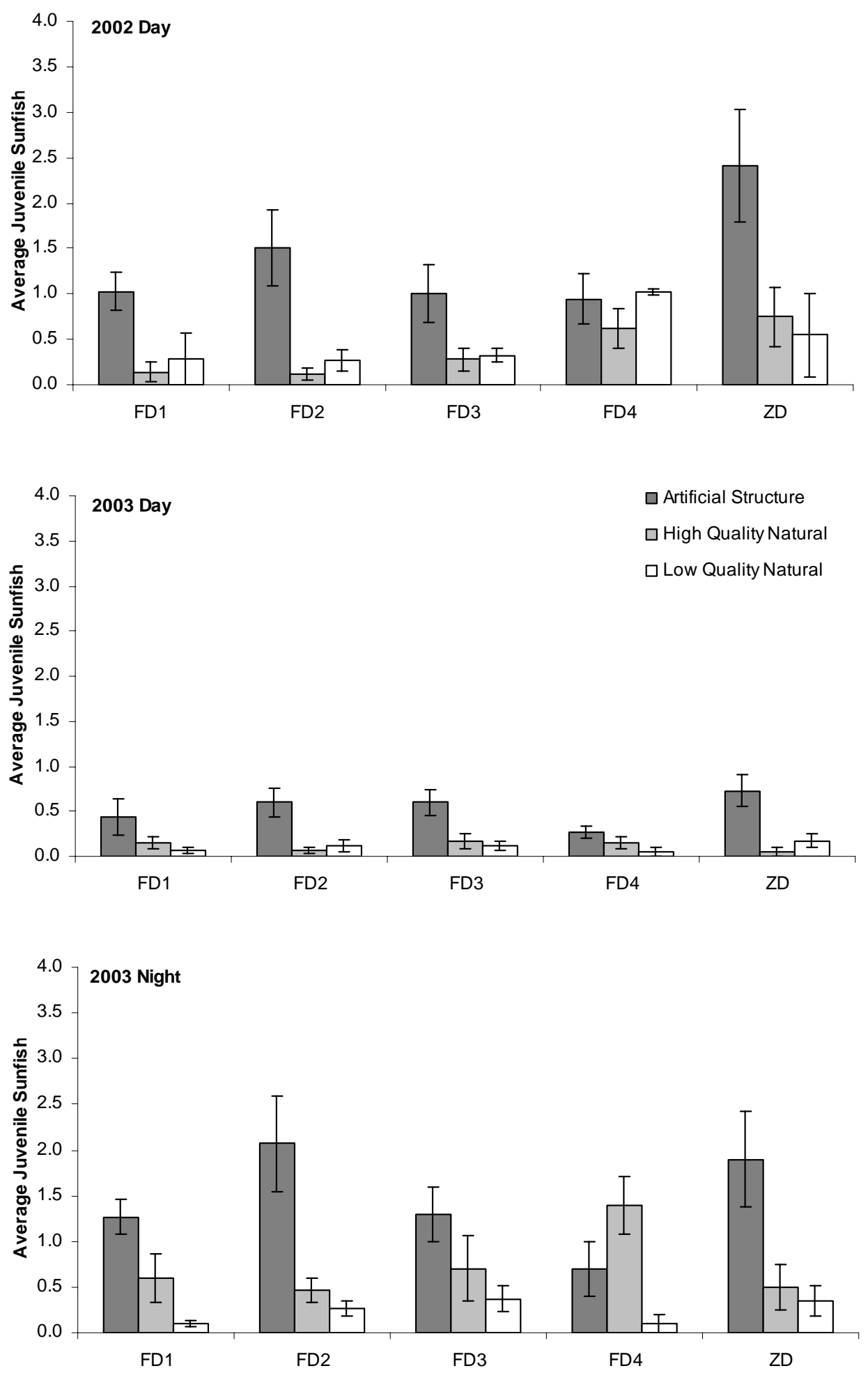

Figure 18 : Average juvenile sunfish (average juvenile sunfish within a site per sample date) within each structure type for artificial structure types and the associated natural reference areas in 2002 and 2003. Error bars represent 95\% confidence intervals. 


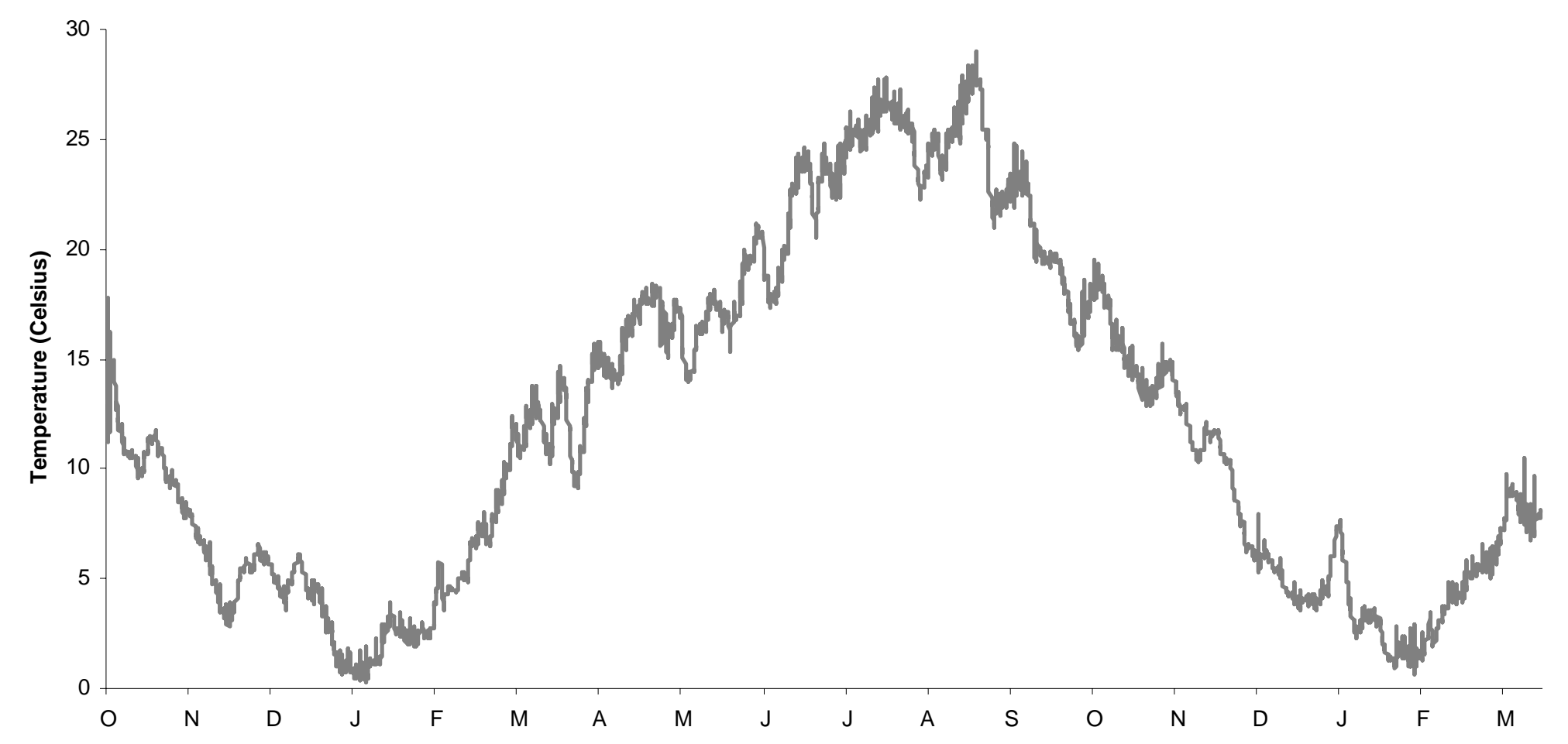

Month

Figure 19 : Water temperature (Celsius) representing all sites (artificial structure and high and low quality natural reference sites). Data resulting from logged temperature information October 28, 2002 through March 17, 2004. Temperature was recorded at 2 hour intervals and collected within each site (15 sites total). 


\section{Sample Site Velocity Profiles}

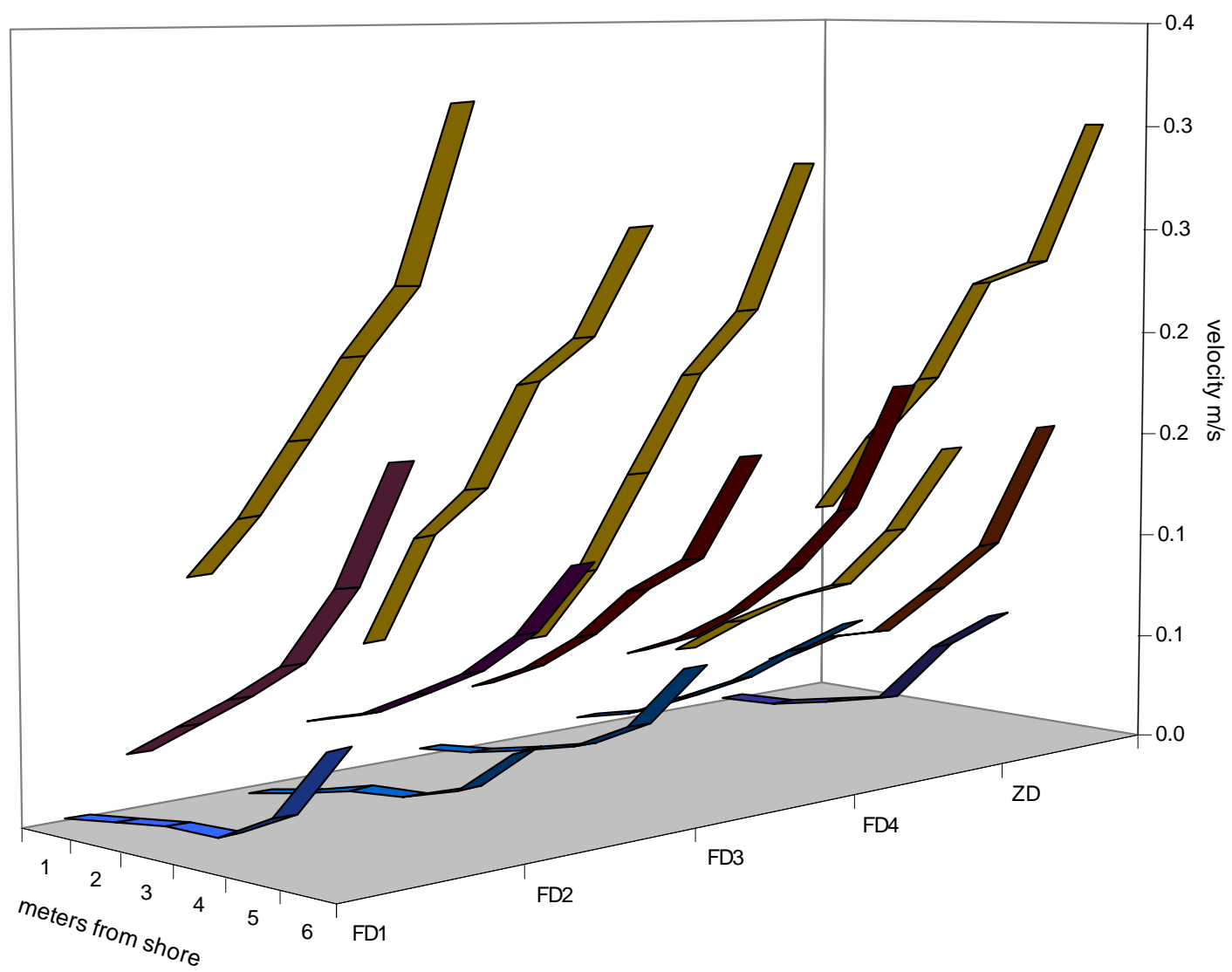

- Artificial Structure

- High Quality Natural Reference

- Low Quality Natural Reference

Figure 20 : Average velocity (meters/second) within each site and its associated high and low quality natural reference areas for Finger Dyke 1 (FD1), Finger Dyke 2 (FD2), Finger Dyke 3 (FD3), Finger Dyke 4 (FD4), and Zipper Dyke (ZD). Measurements begin near shore (1 meter) and move linearly away from shore (6 meters). 


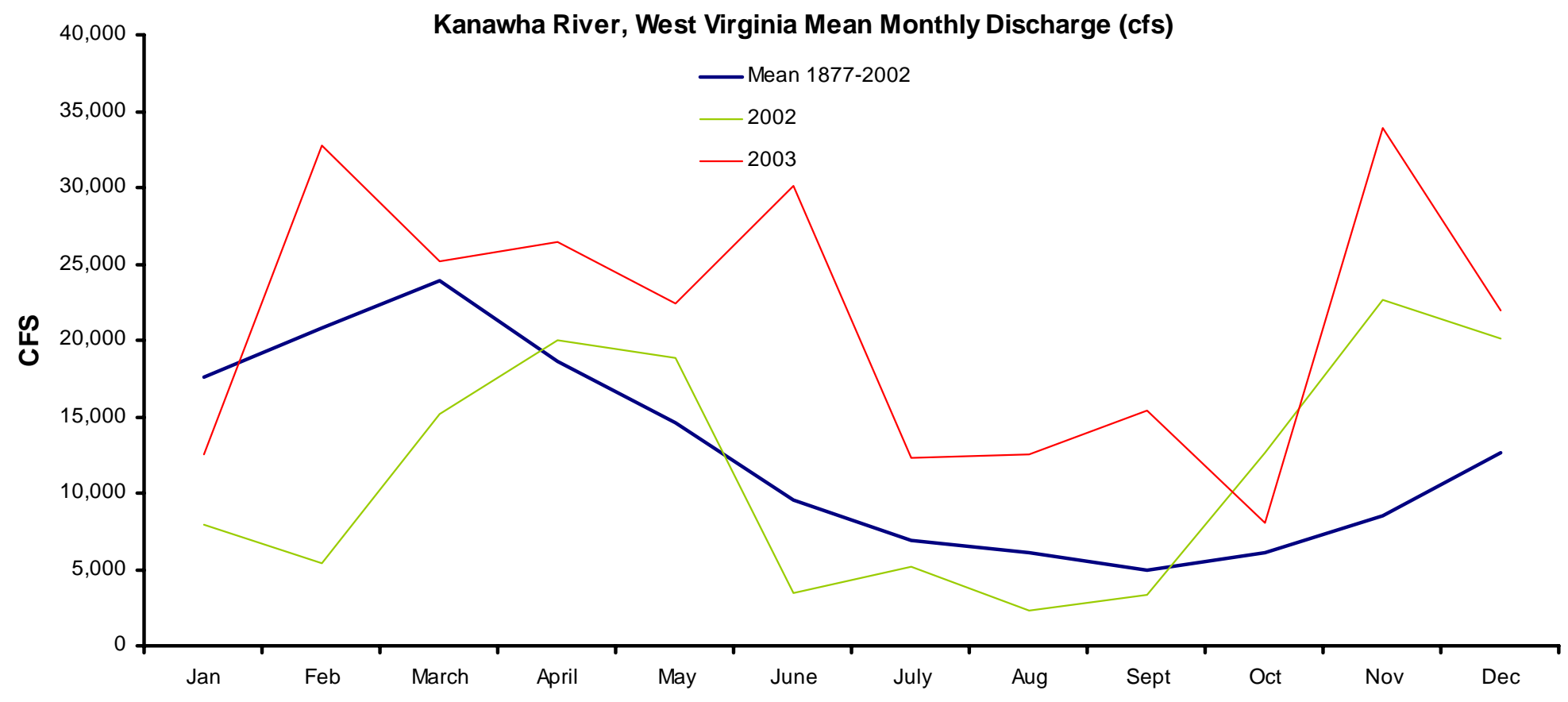

Figure 21: Mean monthly averages for 2002 and 2003 compared to the historic mean discharge from 1877 to 2002 for the Kanawha River, West Virginia (Data from USGS gage 03193000 Kanawha Falls, WV). 

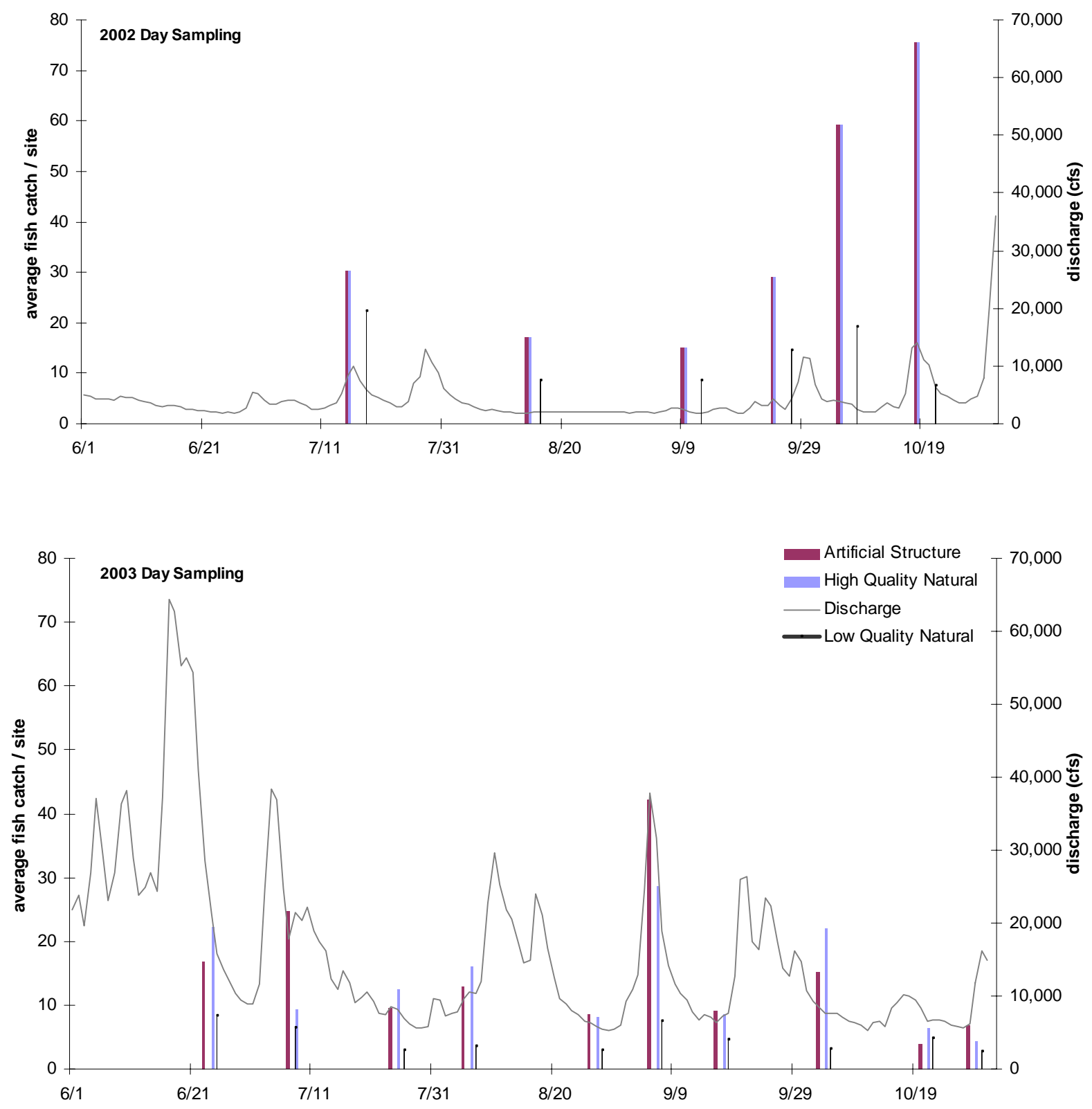

Figure 22 : Average catch (total catch per site / effort) for artificial structures, high quality natural reference and low quality natural reference for each sample date in relation to river discharge for 2002 day sampling and 2003 day sampling. 
Section Eight: Tables 
Table 1 : Structure characteristics for each set of artificial structures. (a.) Measurements within each structure type (feet) and structure density values. See Figure 4 and Figure 5 for the maps from which this data originated. Numbers after each title correspond to the diagram labels below. Density measures are as follows : "Shoreline ft / dyke" = length of shoreline / number of dykes, "Dyke length : distance between dykes" = distance between dykes / average dyke length. (b.) Diagram describes how measurements within table were calculated for each artificial structure site.

(a.)

\begin{tabular}{|c|c|c|c|c|c|c|}
\hline A ntificiol & $\begin{array}{c}\text { Total } \\
\text { Length of }\end{array}$ & Number of & $\begin{array}{c}\text { Average } \\
\text { Length }\end{array}$ & $\begin{array}{l}\text { Average } \\
\text { Distance }\end{array}$ & Density & $\underline{\text { Measures }}$ \\
\hline Structure & $\begin{array}{l}\text { Site } \\
\text { (1) }\end{array}$ & $\begin{array}{c}\text { Dykes } \\
\text { (2) }\end{array}$ & $\begin{array}{c}\text { of Dykes } \\
\text { (3) }\end{array}$ & $\begin{array}{c}\text { Between } \\
\text { Dykes } \\
(4)\end{array}$ & $\begin{array}{l}\text { shoreline } \\
\text { ft / dyke }\end{array}$ & $\begin{array}{c}\text { dyke length : } \\
\text { distance } \\
\text { between dykes }\end{array}$ \\
\hline Finger Dyke 1 & 465 & 10 & 30 & 45 & 46 & 1.5 \\
\hline Finger Dyke 2 & 600 & 16 & 36 & 60 & 37 & 1.6 \\
\hline Finger Dyke 3 & 600 & 8 & 36 & 36 & 75 & 1 \\
\hline Finger Dyke 4 & 705 & 13 & 39 & 53 & 54 & 1.3 \\
\hline Zipper Dyke & 390 & $\begin{array}{c}8 \text { (4 small, } 4 \\
\text { large) }\end{array}$ & $24 \& 60$ & 15 & 48 & 3 \\
\hline
\end{tabular}

(b.)

$(1)$

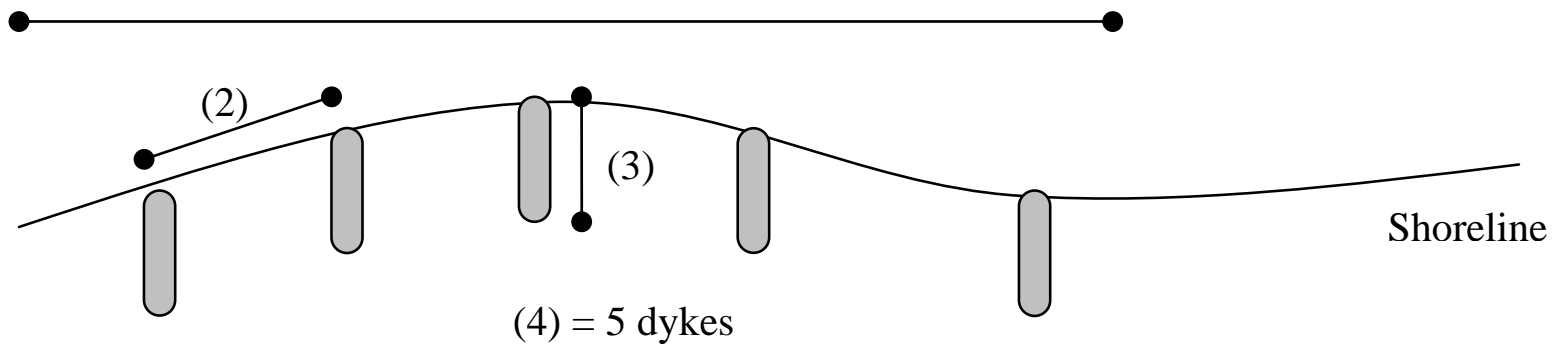


Table 2 : Listing of all dates sampling was conducted. Dates are listed for juvenile point-abundance sampling (day 2002, day 2003, night 2003) and for adult transect sampling (adult sample).

\begin{tabular}{|c|c|c|c|}
\hline & & \\
\hline \multicolumn{3}{|c|}{ Juvenile Sampling Dates } & \multirow{2}{*}{ Adult Sample } \\
\hline Day Samples 2002 & Day Samples 2003 & Night Samples 2003 & Dates \\
\hline & June 23, 2003 & June 11, 2003 & March 15, 2003 \\
\hline July 15, 2002 & July 7, 2003 & & June 11, 2003 \\
\hline & July 24, 2003 & July 13, 2003 & August 3 - 6, 2003 \\
\hline August 14, 2002 & August 5, 2003 & & \\
\hline & August 26, 2003 & August 11, 2003 & October 15 - 16, 2003 \\
\hline September 9, 2002 & September 5, 2003 & October 1, 2003 & \\
\hline September 24, 2002 & September 16, 2003 & & \\
\hline October 5, 2002 & October 3, 2003 & October 29, 2003 & \\
\hline October 18, 2002 & October 20, 2003 & & \\
\hline & October 28, 2003 & & \\
\hline
\end{tabular}


Table 3 : Average number of fish collected within study sites for 2002 and 2003 sampling seasons, Kanawha River, Marmet Pool, West Virginia. Average number is total catch in that group divided by the number of sample dates (10 dates in 2003, 6 dates in 2002). Species diversity is strictly the average species diversity within that site. Significant differences between sites are listed ("struc" : artificial structure, "HQ" : high quality natural reference site, "LQ" : low quality natural reference site, "NS" : no difference between any sites. Alpha is $0.05 . \mathrm{p}<.01$ or less in all cases

\begin{tabular}{|c|c|c|c|c|}
\hline & \multicolumn{3}{|c|}{ Reference Sites } & \multirow[b]{2}{*}{$\begin{array}{l}\text { Significant } \\
\text { Differences }\end{array}$} \\
\hline & $\begin{array}{l}\text { Artificial } \\
\text { Structure }\end{array}$ & $\begin{array}{l}\text { High Quality } \\
\text { Natural }\end{array}$ & $\begin{array}{c}\text { Low Quality } \\
\text { Natural }\end{array}$ & \\
\hline \multicolumn{5}{|l|}{ Day 2002} \\
\hline Catostomidae & -- & -- & -- & -- \\
\hline Black Bass & 18 & 10 & 5 & Struc > HQ, LQ \\
\hline Juvenile Black Bass & 18 & 9 & 5 & Struc $>\mathrm{HQ}, \mathrm{LQ}$ \\
\hline Sunfish & 37 & 10 & 13 & Struc > HQ, LQ \\
\hline Juvenile Sunfish & 37 & 10 & 12 & Struc > LQ,HQ \\
\hline Cyprinidae & 111 & 145 & 31 & $\mathrm{HQ}$, Struc $>\mathrm{LQ}$ \\
\hline Total Catch & 188 & 180 & 67 & Struc, $H Q$ > LQ \\
\hline Species Richness & 7 & 5 & 4 & Struc $>\mathrm{HQ}, \mathrm{LQ}$ \\
\hline \multicolumn{5}{|l|}{ Day 2003} \\
\hline Catostomidae & 3 & 5 & 1 & $\mathrm{HQ}>\mathrm{LQ}$ \\
\hline Black Bass & 7 & 6 & 4 & Struc $>$ LQ \\
\hline Juvenile Black Bass & 5 & 5 & 3 & NS \\
\hline Sunfish & 17 & 5 & 5 & Struc $>$ LQ, HQ \\
\hline Juvenile Sunfish & 14 & 4 & 3 & Struc $>\mathrm{HQ}, \mathrm{LQ}$ \\
\hline Cyprinidae & 31 & 31 & 6 & $\mathrm{HQ}$, Struc > LQ \\
\hline Total Catch & 75 & 69 & 24 & Struc, HQ > LQ \\
\hline Species Richness & 4 & 4 & 3 & Struc $>\mathrm{HQ}, \mathrm{LQ}$ \\
\hline \multicolumn{5}{|l|}{ Night 2003} \\
\hline Catostomidae & 15 & 19 & 6 & $\mathrm{HQ}$, Struc $>\mathrm{LQ}$ \\
\hline Black Bass & 16 & 7 & 4 & Struc $>\mathrm{HQ}, \mathrm{LQ}$ \\
\hline Juvenile Black Bass & 12 & 6 & 3 & Struc $>\mathrm{HQ}, \mathrm{LQ}$ \\
\hline Sunfish & 46 & 23 & 9 & Struc $>\mathrm{HQ}>\mathrm{LQ}$ \\
\hline Juvenile Sunfish & 41 & 22 & 7 & Struc $>\mathrm{HQ}>\mathrm{LQ}$ \\
\hline Cyprinidae & 69 & 59 & 22 & Struc, HQ > LQ \\
\hline Total Catch & 170 & 135 & 63 & Struc $>\mathrm{HQ}>\mathrm{LQ}$ \\
\hline Species Richness & 10 & 9 & 5 & Struc, HQ > LQ \\
\hline
\end{tabular}


Table 4 : Sum (sum of five sites) of fish collected using transect method for adult sampling for each sample date in 2003. Fish listed are placed within abundant species groups for each of artificial structure and high and low quality natural reference sites. "Total Catch" is the sum of all fish collected on that date. Species diversity is listed as an average (average among five sites) for that sample date within that site.

\begin{tabular}{|c|c|c|c|c|}
\hline & & & Referenc & Sites \\
\hline Adult Sample Date & Species Group & $\begin{array}{l}\text { Artificial } \\
\text { Structure } \\
\end{array}$ & $\begin{array}{c}\text { High Quality } \\
\text { Natural }\end{array}$ & $\begin{array}{r}\text { Low Qua } \\
\text { Natura } \\
\end{array}$ \\
\hline March 15, 2003 & Black Bass & 23 & 5 & 9 \\
\hline & Sunfish & 31 & 0 & 2 \\
\hline & Cyprinidae & 60 & 272 & 28 \\
\hline & Sauger & 0 & 0 & 0 \\
\hline & Catostomidae & 3 & 2 & 5 \\
\hline & Gizzard Shad & 0 & 0 & 0 \\
\hline & Total Catch & 212 & 558 & 87 \\
\hline & Avg. Species Richness & 5.8 & 4.8 & 3.2 \\
\hline June 11, 2003 & Black Bass & 3 & 2 & 3 \\
\hline & Sunfish & 11 & 1 & 1 \\
\hline & Cyprinidae & 43 & 6 & 9 \\
\hline & Sauger & 7 & 6 & 2 \\
\hline & Catostomidae & 14 & 29 & 13 \\
\hline & Gizzard Shad & 54 & 39 & 27 \\
\hline & Total Catch & 207 & 123 & 82 \\
\hline & Avg. Species Richness & 7.2 & 6.6 & 4.6 \\
\hline August 8, 2003 & Black Bass & 35 & 13 & 14 \\
\hline & Sunfish & 43 & 27 & 17 \\
\hline & Cyprinidae & 81 & 119 & 87 \\
\hline & Sauger & 0 & 0 & 2 \\
\hline & Catostomidae & 10 & 10 & 1 \\
\hline & Gizzard Shad & 1 & 0 & 2 \\
\hline & Total Catch & 320 & 337 & 240 \\
\hline & Avg. Species Richnes & 11.2 & 8.6 & 7.4 \\
\hline October 16, 2003 & Black Bass & 33 & 22 & 9 \\
\hline & Sunfish & 60 & 20 & 8 \\
\hline & Cyprinidae & 9 & 23 & 2 \\
\hline & Sauger & 3 & 4 & 2 \\
\hline & Catostomidae & 29 & 20 & 6 \\
\hline & Gizzard Shad & 3 & 9 & 8 \\
\hline & Total Catch & 246 & 177 & 63 \\
\hline & Avg. Species Richness & 10.2 & 10.6 & 5.8 \\
\hline
\end{tabular}


Table 5 : Species listing for 2002 day sampling. Numbers are sum of all dates within a site for that species.

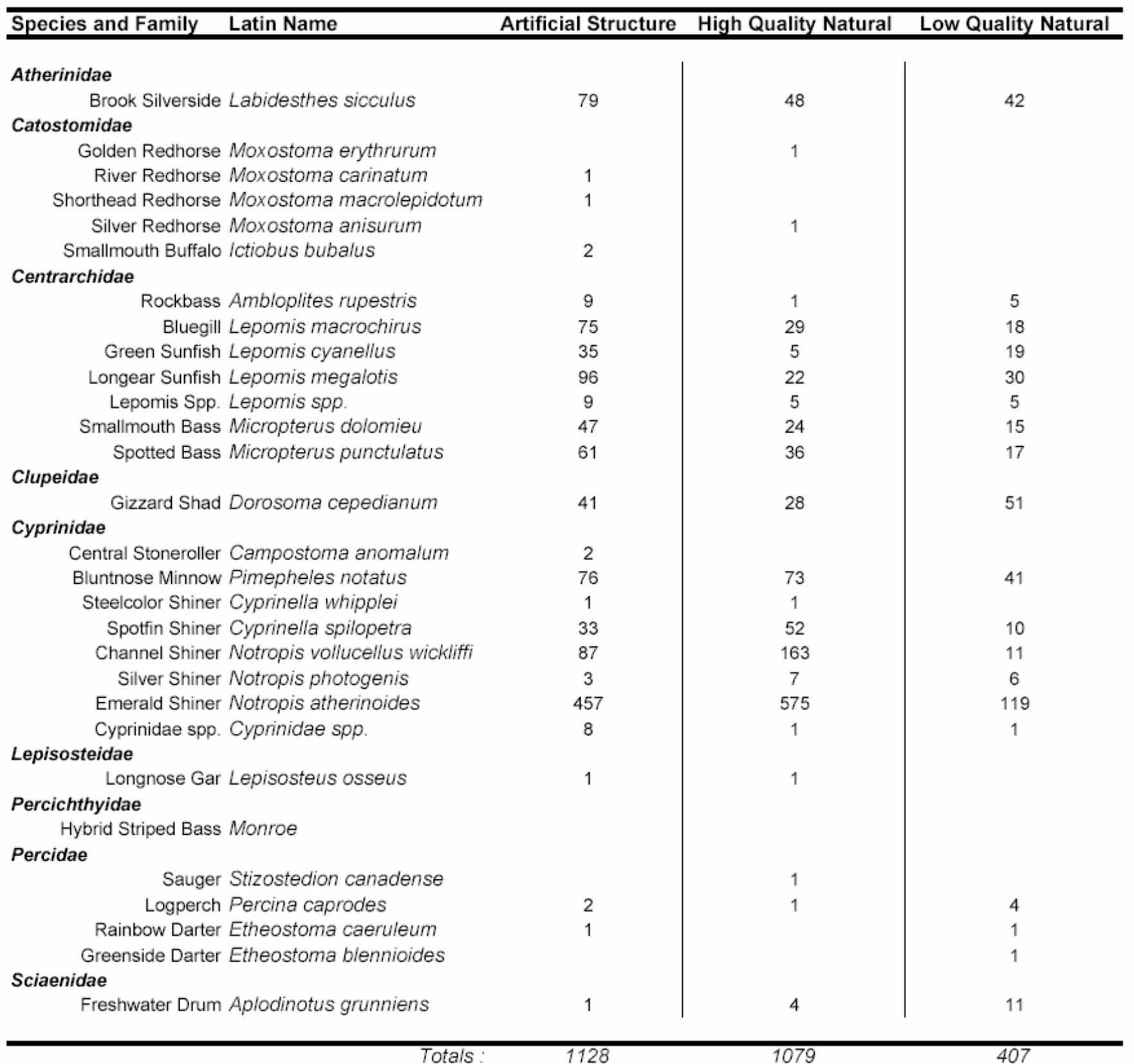


Table 6 : Species listing for 2003 day sampling. Numbers are sum of all dates within a site for that species.

Species and Family Latin Name Artificial Structure High Quality Natural Low Quality Natural

Atherinidae

Brook Silverside Labidesthes sicculus

10

Catostomidae

Golden Redhorse Moxostoma erythrurum

River Redhorse Moxostoma carinatum

Silver Redhorse Moxostoma anisurum

Moxostoma spp. Moxostoma species

Smallmouth Buffalo Ictiobus bubalus

Quillback Carpsucker Carpiodes cyprinus

River Carpsucker Carpiodes carpio

Highfin Carpsucker Carpiodes velifer

Centrarchidae

Rockbass Ambloplites rupestris

Bluegill Lepomis macrochirus

Green Sunfish Lepomis cyanellus

Longear Sunfish Lepomis megalotis

Lepomis Spp. Lepomis spp.

Smallmouth Bass Micropterus dolomieu

Spotted Bass Micropterus punctulatus

Clupeidae

Gizzard Shad Dorosoma cepedianum 128

Skip Jack Alosa chrysochloris $\quad 1$

Cyprinidae

Carp Cyprinus carpio

Big Eye Chub Hybopsis amblops

7

6

13

2

2

19

11

48

84

3

44

21

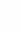

18

Bluntnose Minnow Pimepheles notatus

Spotfin Shiner Cyprinella spilopetra

Whitetail Shiner Cyprinella galactura

Cyprinella spp. Cyprinella spp.

Channel Shiner Notropis vollucellus wickliffi

Mimic Shiner Notropis vollucellus

Notropis vollucellus spp. Notropis vollucellus $s p p$.

Spottail Shiner Notropis hudsonius

Emerald Shiner Notropis atherinoides

Cyprinidae spp. Cyprinidae spp.

Ictaluridae

Flathead Catfish Pylodictis olivaris

Channel Catfish Ictalurus punctatus

Lepisosteidae

Longnose Gar Lepisosteus osseus

\section{Percichthyidae}

Hybrid Striped Bass Monroe

Percidae

Logperch Percina caprodes

Sauger Stizostedion canadense

Sciaenidae

Percidae Larval Percidae larval

Freshwater Drum Aplodinotus grunniens

(n)

10

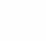

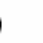

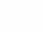


Table 7 : Species listing for 2003 night sampling. Numbers are sum of all dates within a site for that species.

\begin{tabular}{|c|c|c|c|}
\hline Species and Family Latin Name & Artificial Structure & High Quality Natural & Low Quality Natural \\
\hline \multicolumn{4}{|l|}{ Atherinidae } \\
\hline Brook Silverside Labidesthes sicculus & 2 & 2 & \\
\hline \multicolumn{4}{|l|}{ Catostomidae } \\
\hline Black Redhorse Moxostoma duquesnei & 3 & 5 & 2 \\
\hline Golden Redhorse Moxostoma erythrurum & 15 & 18 & 3 \\
\hline River Redhorse Moxostoma carinatum & 4 & 5 & 4 \\
\hline Shorthead Redhorse Moxostoma macrolepidotum & 2 & 2 & 5 \\
\hline Silver Redhorse Moxostoma anisurum & 6 & 14 & 2 \\
\hline Moxostoma spp. Moxostoma spp. & 8 & 12 & \\
\hline Smallmouth Buffalo Ictiobus bubalus & 16 & 19 & 7 \\
\hline Highfin Carpsucker Carpiodes velifer & 1 & 0 & 1 \\
\hline Quillback Carpsucker Carpiodes cyprinus & 4 & 4 & 3 \\
\hline River Carpsucker Carpiodes carpio & 14 & 17 & 2 \\
\hline \multicolumn{4}{|l|}{ Centrarchidae } \\
\hline Rockbass Ambloplites rupestris & 10 & 6 & 6 \\
\hline Bluegill Lepomis macrochirus & 13 & 14 & 7 \\
\hline Green Sunfish Lepomis cyanellus & 20 & & 5 \\
\hline Green Sunfish Hybrid Lepomis & 1 & & \\
\hline Longear Sunfish Lepomis megalotis & 159 & 89 & 25 \\
\hline Lepomis Spp. Lepomis spp. & 28 & 7 & 2 \\
\hline Smallmouth Bass Micropterus dolomieu & 49 & 21 & 11 \\
\hline Spotted Bass Micropterus punctulatus & 29 & 16 & 8 \\
\hline \multicolumn{4}{|l|}{ Clupeidae } \\
\hline Gizzard Shad Dorosoma cepedianum & 35 & 66 & 59 \\
\hline Skip Jack Alosa chrysochloris & & & 1 \\
\hline \multicolumn{4}{|l|}{ Cyprinidae } \\
\hline Carp Cyprinus carpio & 1 & 2 & 1 \\
\hline Big Eye Chub Hybopsis amblops & 16 & 24 & 9 \\
\hline Bluntnose Minnow Pimepheles notatus & 5 & 4 & 4 \\
\hline Spotfin Shiner Cyprinella spilopetra & 6 & 4 & \\
\hline Cyprinella spp. Cyprinella spp. & 7 & & \\
\hline Channel Shiner Notropis vollucellus wickliffi & 162 & 128 & 31 \\
\hline Mimic Shiner Notropis vollucellus & 45 & 46 & 5 \\
\hline Notropis vollucellus spp. Notropis vollucellus spp. & 20 & 5 & \\
\hline Emerald Shiner Notropis atherinoides & 47 & 38 & 32 \\
\hline Spottail Shiner Notropis hudsonius & & 4 & \\
\hline Cyprinidae spp. Cyprinidae spp. & 34 & 40 & 29 \\
\hline \multicolumn{4}{|l|}{ Ictaluridae } \\
\hline Flathead Catfish Pylodictis olivaris & 2 & 2 & 2 \\
\hline Channel Catfish Ictalurus punctatus & & 3 & 3 \\
\hline \multicolumn{4}{|l|}{ Lepisosteidae } \\
\hline Longnose Gar Lepisosteus osseus & 3 & 2 & 2 \\
\hline \multicolumn{4}{|l|}{ Percichthyidae } \\
\hline Hybrid Striped Bass Monroe & 11 & 8 & 5 \\
\hline \multicolumn{4}{|l|}{ Percidae } \\
\hline Sauger Stizostedion canadense & 17 & 18 & 13 \\
\hline Walleye Stizostedion vitreum & 2 & 1 & \\
\hline Logperch Percina caprodes & 2 & 1 & 2 \\
\hline Percidae Larval Percidae lanval & 1 & & \\
\hline \multicolumn{4}{|l|}{ Esocidae } \\
\hline Musky Esox masquinongy & & 1 & \\
\hline \multicolumn{4}{|l|}{ Petromyzontidae } \\
\hline American Brook Lamprey Lampetra appendix & 1 & & \\
\hline \multicolumn{4}{|l|}{ Sciaenidae } \\
\hline Freshwater Drum Aplodinotus grunniens & 47 & 27 & 26 \\
\hline
\end{tabular}


Table 8 : Adult sampling species presence absence data. "x" represents presence of a species within a site at last once during the adult sampling collections (March, June, August, and October 2003).

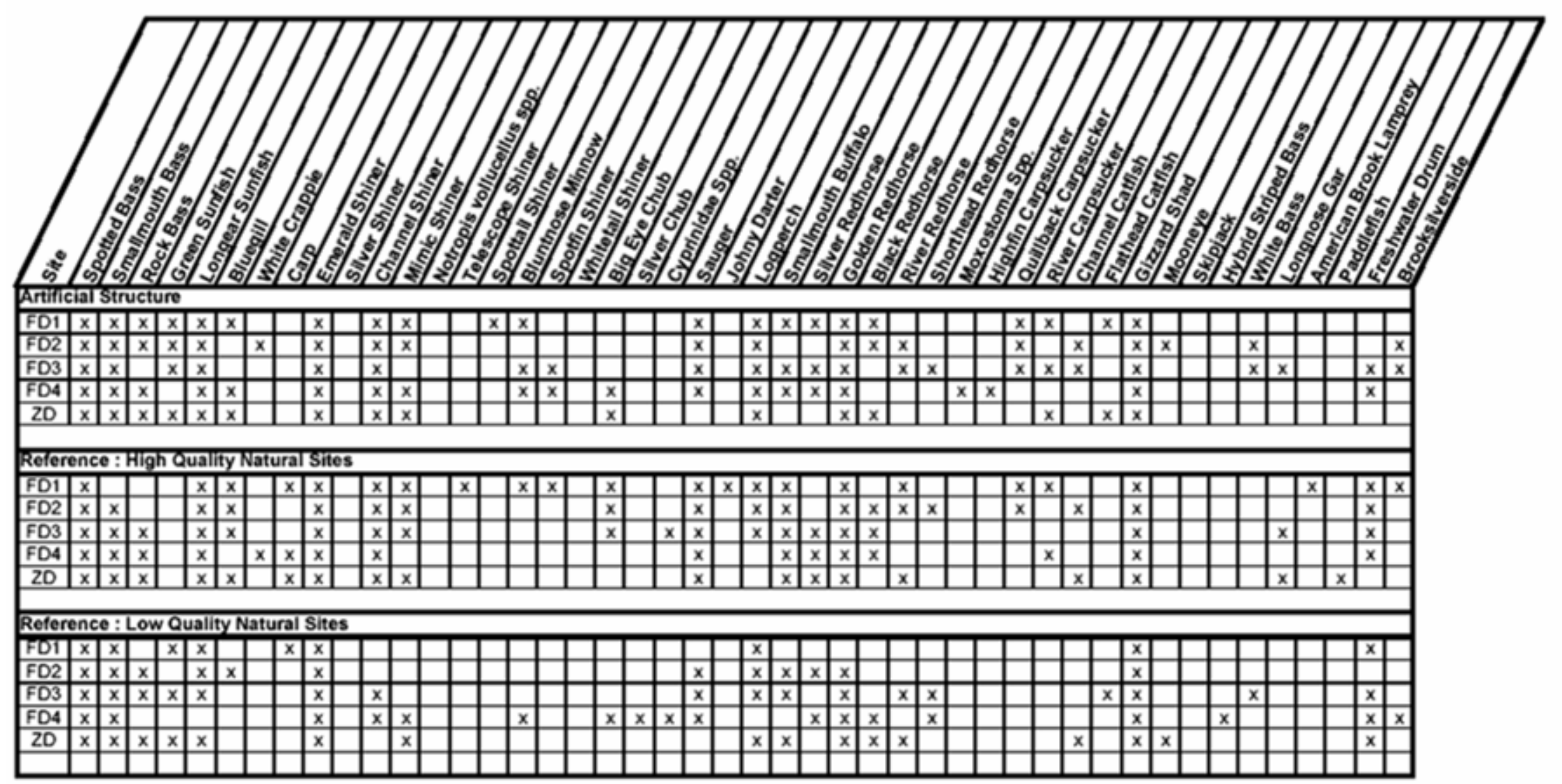


Table 9: Average water quality data among all sites for the 2002 and 2003 sampling seasons. Water quality was measured once per site (15 total / sample date) using a YSI water quality meter at 1 meter depth.

\begin{tabular}{|c|c|c|c|c|c|c|c|}
\hline Date & $\begin{array}{c}\text { Temperature } \\
\text { ( Celsius ) }\end{array}$ & $\begin{array}{c}\text { Dissolved } \\
\text { Oxygen } \\
\text { ( mg / liter ) } \\
\end{array}$ & $\begin{array}{c}\text { Specific } \\
\text { Conductivity } \\
\mu S / \mathrm{cmc}\end{array}$ & $\begin{array}{c}\text { Conductivity } \\
\mathrm{mS} / \mathrm{cm}\end{array}$ & $\begin{array}{c}\text { Salinity } \\
\text { (ppt ) }\end{array}$ & pH & $\begin{array}{c}\text { Turbidity } \\
\text { ( NTU ) }\end{array}$ \\
\hline 9/9/2002 & 28.75 & 7.60 & 286 & 0.307 & 0.13 & 7.72 & 5.9 \\
\hline $9 / 24 / 2002$ & 25.41 & 7.89 & 317 & 0.319 & 0.15 & 8.07 & 8.1 \\
\hline $10 / 5 / 2002$ & 24.14 & 8.54 & 305 & 0.300 & 0.14 & 7.53 & 29.1 \\
\hline $10 / 5 / 2002$ & 23.81 & 8.76 & 305 & 0.299 & 0.14 & 7.41 & 5.3 \\
\hline $10 / 18 / 2002$ & 16.04 & 11.29 & 255 & 0.212 & 0.12 & 8.55 & 16.2 \\
\hline $3 / 15 / 2003$ & 8.62 & 13.63 & 287 & 0.199 & 0.14 & 7.42 & 14.8 \\
\hline $6 / 10 / 2003$ & 17.77 & 5.44 & 363 & 0.237 & 0.12 & 8.15 & 18.7 \\
\hline $6 / 23 / 2003$ & 20.27 & 6.14 & 276 & 0.250 & 0.13 & 7.97 & 18.3 \\
\hline $7 / 15 / 2003$ & 25.26 & 9.70 & 165 & 0.166 & 0.08 & 8.17 & 8.2 \\
\hline $7 / 24 / 2003$ & 26.12 & 8.37 & 171 & 0.175 & 0.08 & 8.03 & 7.5 \\
\hline $8 / 5 / 2003$ & 26.32 & 7.86 & 202 & 0.207 & 0.09 & 7.96 & 11.3 \\
\hline $8 / 10 / 2003$ & 22.90 & 9.27 & 143 & 0.137 & 0.07 & 7.77 & 80.3 \\
\hline $8 / 26 / 2003$ & 25.62 & 7.46 & 174 & 0.178 & 0.08 & 7.98 & 21.4 \\
\hline 9/5/2003 & 21.74 & 9.86 & 110 & 0.103 & 0.05 & 7.70 & 70.7 \\
\hline 9/16/2003 & 24.88 & 9.35 & 169 & 0.157 & 0.07 & 8.11 & 8.2 \\
\hline $10 / 3 / 2003$ & 19.09 & 9.24 & 162 & 0.142 & 0.08 & 8.08 & 12.4 \\
\hline $10 / 16 / 2003$ & 17.78 & $\mathrm{n} / \mathrm{a}$ & 190 & 0.164 & 0.09 & 8.13 & 17.9 \\
\hline $10 / 28 / 2003$ & 13.90 & 10.30 & 176 & 0.139 & 0.08 & 8.17 & 11.7 \\
\hline
\end{tabular}




\section{Section Nine: Appendices}


Appendix 1 : Photographs : (1) Marmet Pool, Kanawha River (photo by J. Titus), (2) Finger Dyke 4 artificial structure (photo by J. Niles), (3) Typical undeveloped shoreline within Marmet Pool (photo by J. Titus), (4) Artificial structure construction material (photo by J. Titus).

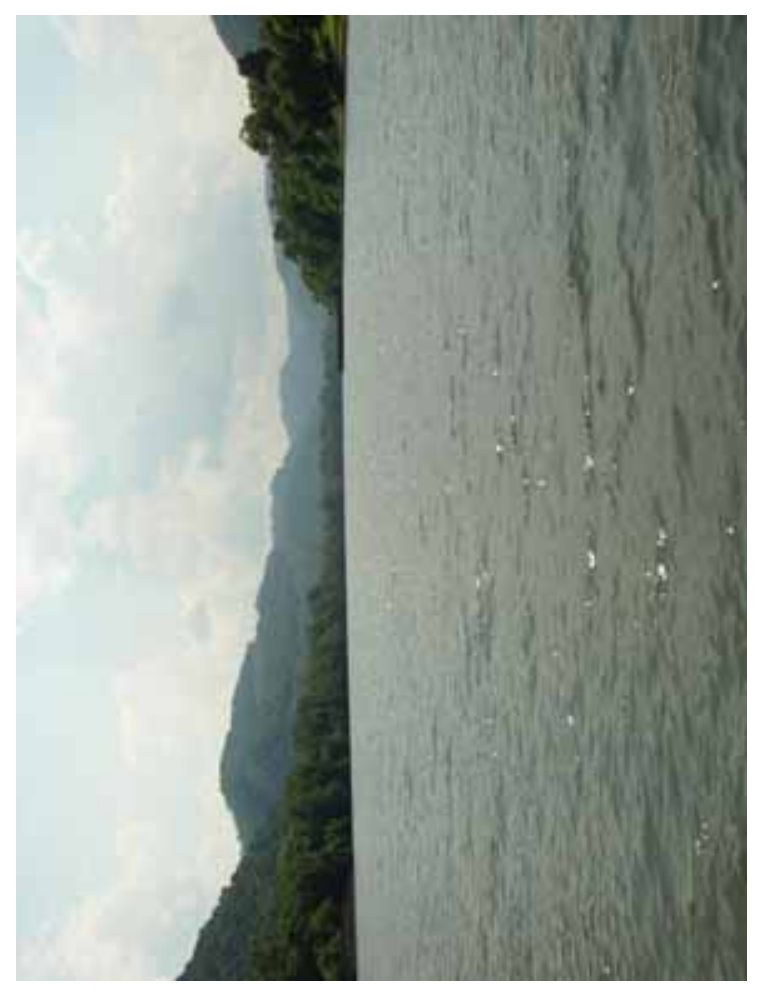

1.

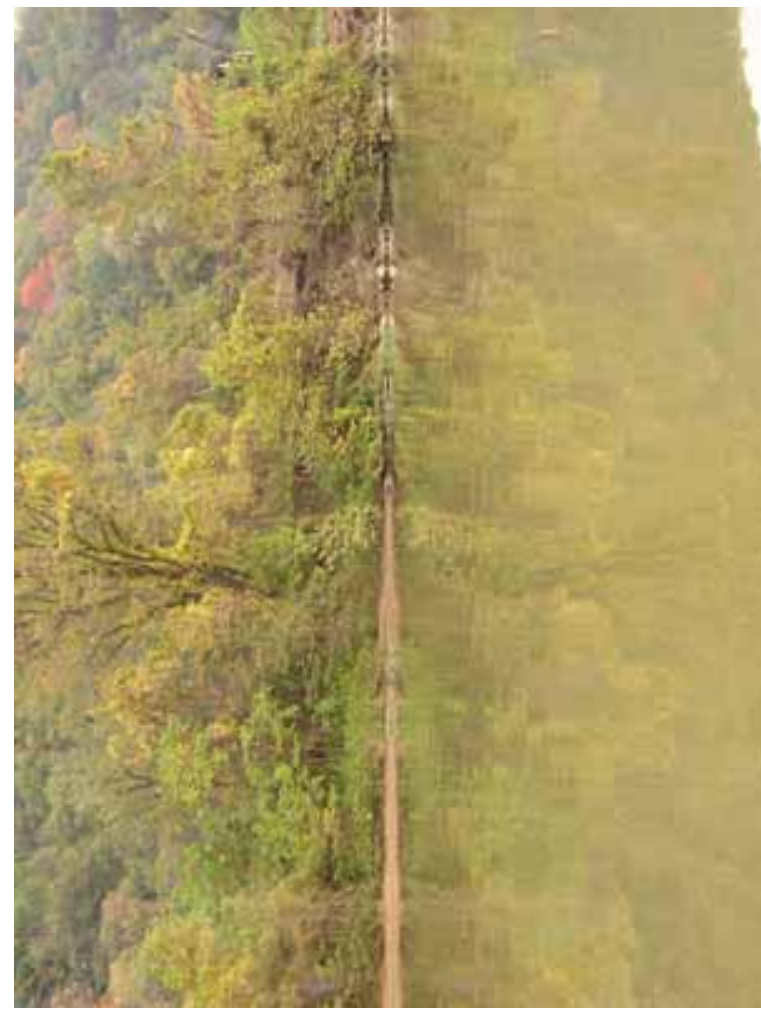

3.

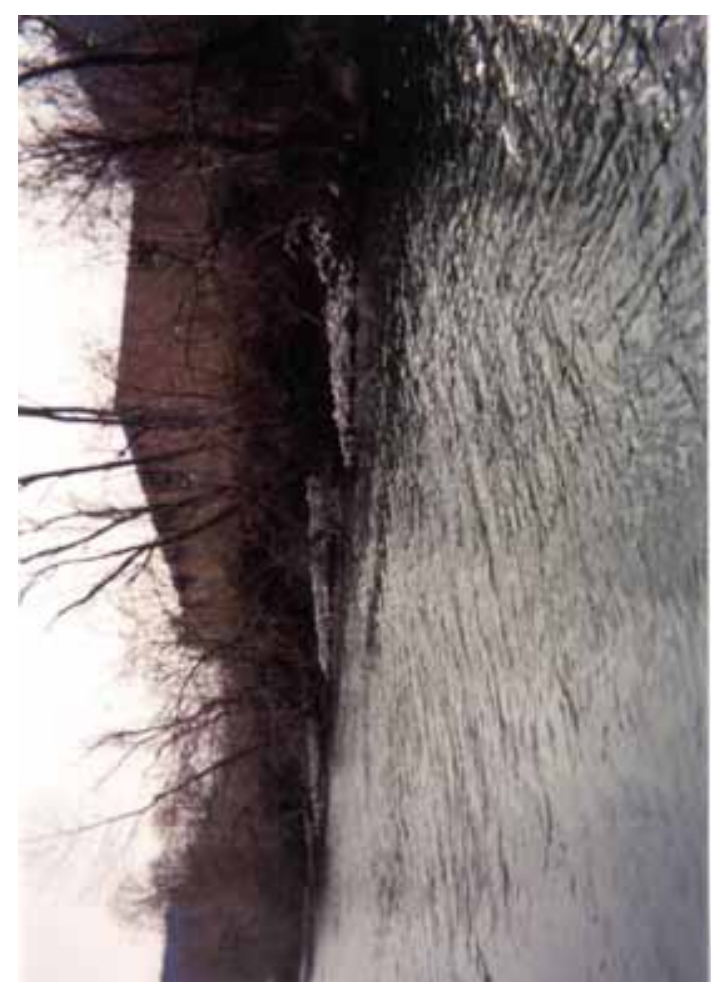

2.

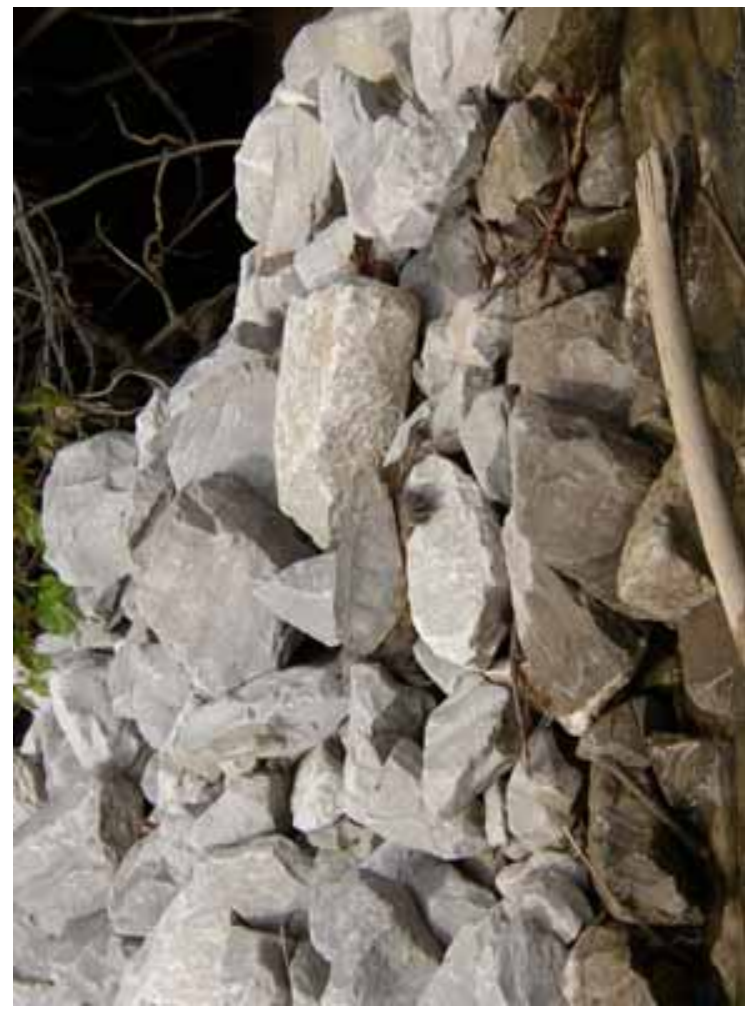

4. 
Appendix 2: Photographs : (1) Netted Fish, (2) Aquatic vegetation often used by small fish, (3) J. Howell 2003, (4) Freshwater Drum, J. Titus 2003. (photos by J. Titus)

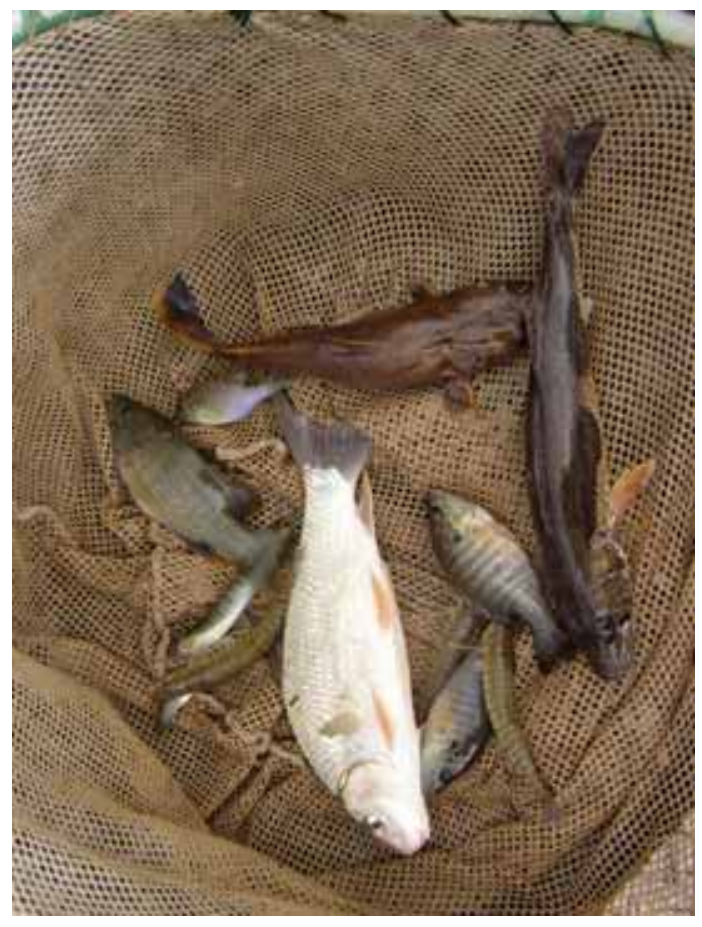

1.

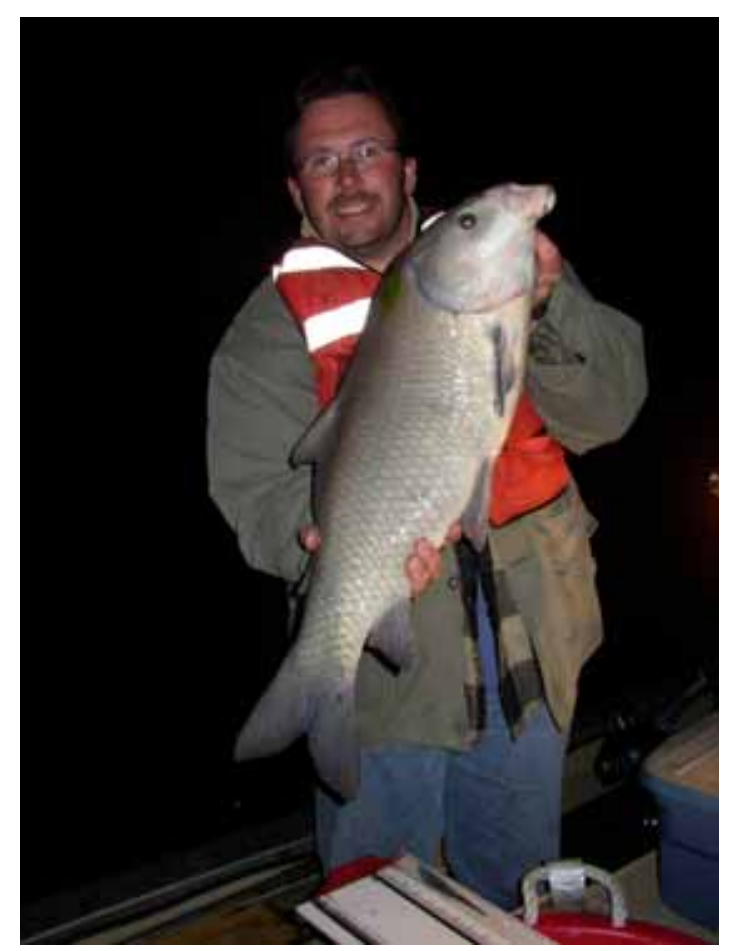

3.

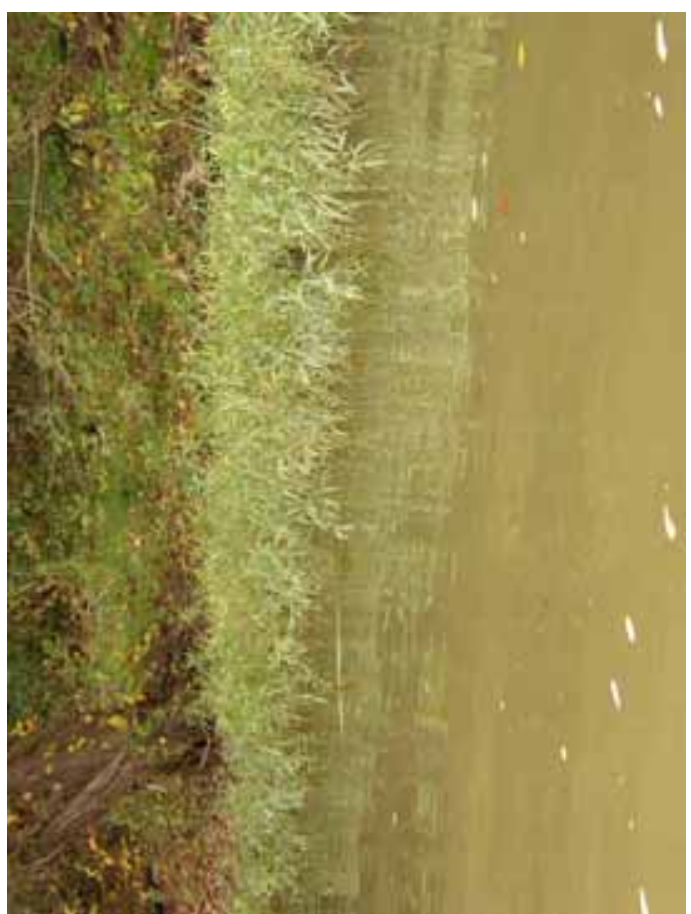

2.

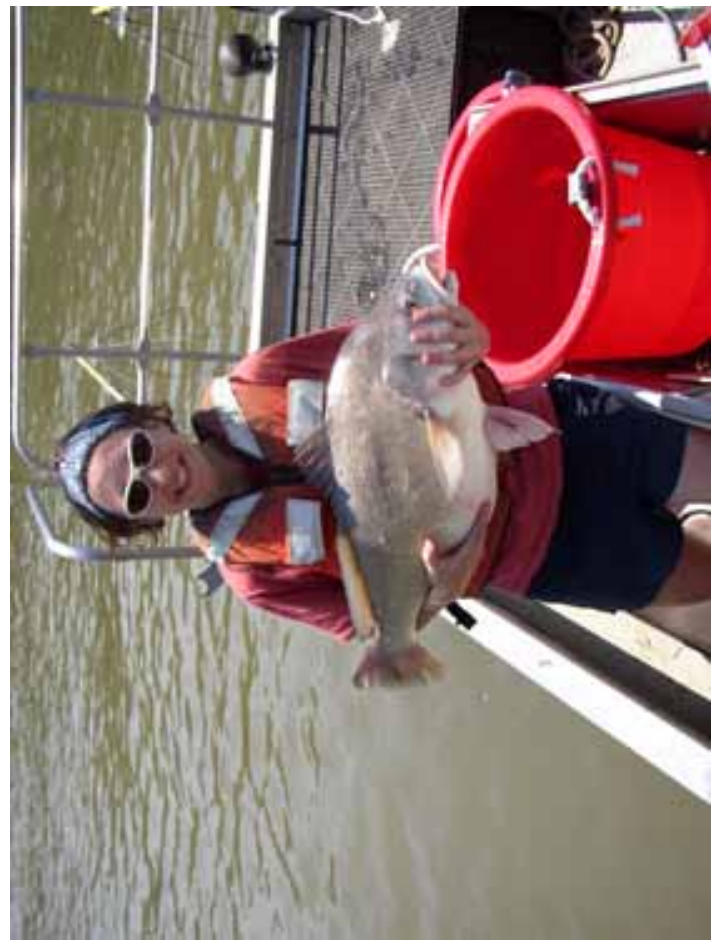

4. 
Appendix 3 : Data analysis summary for ANOVA/GLM procedures. Descriptions listed at the bottom of each column.

\begin{tabular}{|c|c|c|c|c|c|c|c|c|c|}
\hline \multirow{9}{*}{ Day 2002} & Analysis & Transtormation & $\begin{array}{l}\text { Sxentosis, } \\
\text { Kuntosis }\end{array}$ & Date & Silte & Treatment & Structure vs Reference & Site "Trestment & Dyke $>\mathrm{H}$ \\
\hline & $\begin{array}{c}\text { Species Richness } \\
\text { Average Total Catch }\end{array}$ & $\begin{array}{l}\text { none } \\
\text { none }\end{array}$ & $\begin{array}{l}-0.20,-0.40 \\
0.70,1.04\end{array}$ & $\begin{array}{l}0.1858 \\
0.0001\end{array}$ & $\begin{array}{l}0.4145 \\
0.1044\end{array}$ & $\begin{array}{l}0.0001 \\
0.0003\end{array}$ & $\begin{array}{l}\text { Struc }>H, S \\
\text { Struc, } H>S\end{array}$ & $\begin{array}{l}0.2313 \\
0.2593\end{array}$ & $\begin{array}{c}\mathrm{ZD}, \mathrm{FD1},(\mathrm{FD} 2=0.059) \\
(\mathrm{ZD}=0.0847)\end{array}$ \\
\hline & Average Black Bass & none & $0.59,1.50$ & 0.0981 & 0.0111 & 0.0001 & Strue $>\mathrm{H}, \mathrm{S}$ & 0.8420 & $(F D 1, F D 2, F D 4, Z D=.07)$ \\
\hline & Average Jivenuie Bass & none & $0.69,23$ & 0.1205 & 0.0139 & 0.0001 & Strue $>\mathrm{H}, \mathrm{S}$ & 0.9406 & $(Z \mathrm{ZO}, F \mathrm{FO}=0.07)$ \\
\hline & Average Sunfish & none & $0.61,0.96$ & 0.0006 & 0.0014 & 0.0001 & Struc $>\mathrm{H}, \mathrm{S}$ & 0.0196 & $\mathrm{ZD}, \mathrm{FD} 2, \mathrm{FD} 3, \mathrm{FD} 1$ \\
\hline & Average Jivenile Sunfish & none & $0.65,1.28$ & 0.0003 & 0.0014 & 0.0001 & Struc $>\mathrm{S}, \mathrm{H}$ & 0.0387 & $\mathrm{ZD}, \mathrm{FD} 2, \mathrm{FD} 3, \mathrm{FD} 1$ \\
\hline & Average Cyprinitee & none & $0.9,216$ & 0.0001 & 0.5059 & 0.0014 & H, Struc $>\mathrm{S}$ & 0.1467 & NS \\
\hline & Atherinoides & none & $1.15,1.70$ & 0.1415 & 0.0165 & 0.1147 & NS & 0.3972 & 20 \\
\hline & Clupidae & none & $2 \cdot 10.7 .68$ & 0.6586 & 0.5023 & 0.5345 & NS & 0.2202 & $(F D 2=.08)$ \\
\hline \multirow{14}{*}{ Day 2003} & Analysis & Transtormation & Kurtosis & Date & site & Tratement & Dyke vs Reterence & Site " Treatment & Dyke $>\mathrm{H}$ \\
\hline & Species Richness & none & $0.84,2.16$ & 0.0001 & 0.1908 & 0.0001 & H, Strue > S & $\overline{0.2872}$ & FD4 \\
\hline & Average Total Catch & none & $0.67,0.87$ & 0.0001 & 0.0045 & 0.0001 & Struc, $H>S$ & 0.0345 & 20 \\
\hline & Average Black Bass & none & $0.27,1.18$ & 0.0001 & 0.0035 & 0.0277 & Struc $>S, H=S t r u c, H=S$ & 0.5907 & $\mathrm{FD} 1, \mathrm{FO}_{2}$ \\
\hline & Average Jivenile Black Bass & none & $0.47,0.97$ & 0.0001 & 0.0121 & 0.2314 & $=$ & 0.3678 & NS \\
\hline & Average Sunfish & none & $1.30,6.79$ & 0.0001 & 0.1203 & 0.0001 & Strue $>S, H$ & 0.5574 & $\mathrm{ZD}, \mathrm{FD} 2, \mathrm{FD} 3, \mathrm{FD} 1$ \\
\hline & Log Average Sunfish & $\#+1,100$ & $0.20,888$ & 0.0001 & 0.0523 & 0.0001 & Strue $>\mathrm{S}, \mathrm{H}$ & 0.4332 & $\mathrm{ZD}, \mathrm{FD} 2, \mathrm{FD} 3, \mathrm{FD} 1$ \\
\hline & Average Jivenile Suntish & none & $0.76,2.67$ & 0.0001 & 0.0537 & 0.0001 & Strue $>\mathrm{H}, \mathrm{S}$ & 0.1122 & $\mathrm{ZD}, \mathrm{FD2}, \mathrm{FD} 3, \mathrm{FD} 1$ \\
\hline & Log Average Juvenie Sunfish & $\|+1,100$ & $0.28,0.66$ & 0.0001 & 0.0330 & 0.0001 & Strue $>\mathrm{H}, \mathrm{S}$ & 0.0794 & $\mathrm{ZD}, \mathrm{FD} 2, \mathrm{FD} 3$ \\
\hline & Averago Cyprinideo & none & $1.15,2.61$ & 0.0001 & 0.2028 & 0.0001 & $\mathrm{H}$, Strue $>\mathrm{S}$ & 0.0790 & $(F D 2=0.0513)$ \\
\hline & Log Average Cyprinidae & $m+1, \log$ & $0.61,0.76$ & 0.0001 & 0.1244 & 0.0001 & $\mathrm{H}$, Strue $>\mathrm{S}$ & 0.0607 & $(F D 2=0.085)$ \\
\hline & Clupiedae & none & $299,18.73$ & 0.0332 & 0.0882 & 0.0081 & $\mathrm{H}>\mathrm{S}, \mathrm{H}=\mathrm{Struc}$, Struem $\mathrm{S}$ & 0.3780 & FD2 (strue $<\mathrm{H}$ ) \\
\hline & Average Catostomideo & none & 2.13 .824 & 0.1087 & 0.4036 & 0.0104 & $\mathrm{H}>\mathrm{S}, \mathrm{H}=\mathrm{Struc}, \mathrm{Struc}=\mathrm{S}$ & 0.0375 & FD1 \\
\hline & Log Average Catostomides & $\#+1,109$ & 1.50 .4 .26 & 0.0385 & 0.5839 & 0.0073 & $H>S, H=$ Struc, Strue $=S$ & 0.0445 & FD1 \\
\hline \multirow{10}{*}{ Night 03} & Analysis & Transtormation & $\begin{array}{l}\text { Strewness, } \\
\text { Kuntosis }\end{array}$ & Date & sitte & Treatment & Dyke vs Reference & Site " Trestment & Dyke $>\mathrm{H}$ \\
\hline & Species kichness & none & $0.46,071$ & 0,0034 & 0.0173 & 0.0001 & Struc, $H>S$ & 00952 & $\frac{\mathrm{F}_{0}}{\mathrm{Fu}}$ \\
\hline & Average Catch & none & $0.59,1.28$ & 0.0003 & 0.1367 & 0.0001 & Struc $>H>S$ & 0.0044 & FD1 \\
\hline & Average Black Bass & none & $0.53,0.53$ & 0.2640 & 0.8000 & 0.0001 & Strue $>\mathrm{H}, \mathrm{S}$ & 0.9360 & $\mathrm{FD} 3, \mathrm{FO} 2$ \\
\hline & Average Jivenie日 Bass & none & $0.76,1.20$ & 0.5170 & 0.6770 & 0.0015 & Strue $>\mathrm{H}, \mathrm{S}$ & 0.7200 & $\mathrm{FD} 3$ \\
\hline & Averago Sunfish & none & $0.92,1.36$ & 0.0596 & 0.6739 & 0.0001 & Struc $>\mathrm{H}>\mathrm{S}$ & 0.0042 & FD2, ZD, FD3, FD1 \\
\hline & Average Juvenile Sunfish & none & $0.92,1.74$ & 0.0479 & 0.6483 & 0.0001 & Strue $>\mathrm{H}>\mathrm{S}$ & 0.0059 & $\mathrm{FD} 2,2 \mathrm{D}$ \\
\hline & Average Cyprinidee & none & $0.55,0.68$ & 0.0001 & 0.0242 & 0.0002 & Struc, $H>S$ & 0.0119 & FD1 \\
\hline & Average Catostomidao & none & $0.89,1.14$ & 0.0069 & 0.1656 & 0.0032 & H, Stuc $>\mathrm{S}$ & 0.2719 & NS \\
\hline & Log Average Catostomides & $\#+1,109$ & 0.50 .0 .01 & 0.0812 & 0.1403 & 0.0008 & H. Stuc $>S$ & 0.2157 & NS \\
\hline & & $\begin{array}{l}\text { Data Transformatoon } \\
\text { to achieve normality }\end{array}$ & $\begin{array}{c}\text { Normaility } \\
\text { estimation } \\
\text { value }-1 \text { to }+1 \\
=\text { normaility }\end{array}$ & $\begin{array}{l}\text { Sin figh } \\
\text { by sample } \\
\text { date }\end{array}$ & $\begin{array}{c}\Delta \text { in fish } \\
\text { by set of } \\
\text { sites }\end{array}$ & $\begin{array}{l}\Delta \text { in fish } \\
\text { in Struc, High Q. } \\
\text { \& Low Q. }\end{array}$ & $\begin{array}{l}\text { Struc = Art Structure } \\
H=\text { High Quality Ref. } \\
S=\text { Low Quality Ref. } \\
\text { NS = Not Significant }\end{array}$ & $\begin{array}{l}\text { in figh } \\
\text { between strue } \\
\text { \& ref within } \\
\text { sites }\end{array}$ & 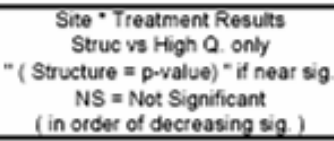 \\
\hline
\end{tabular}


Appendix 4 : Artificial Structure Collection Totals - 2002 Day Sampling

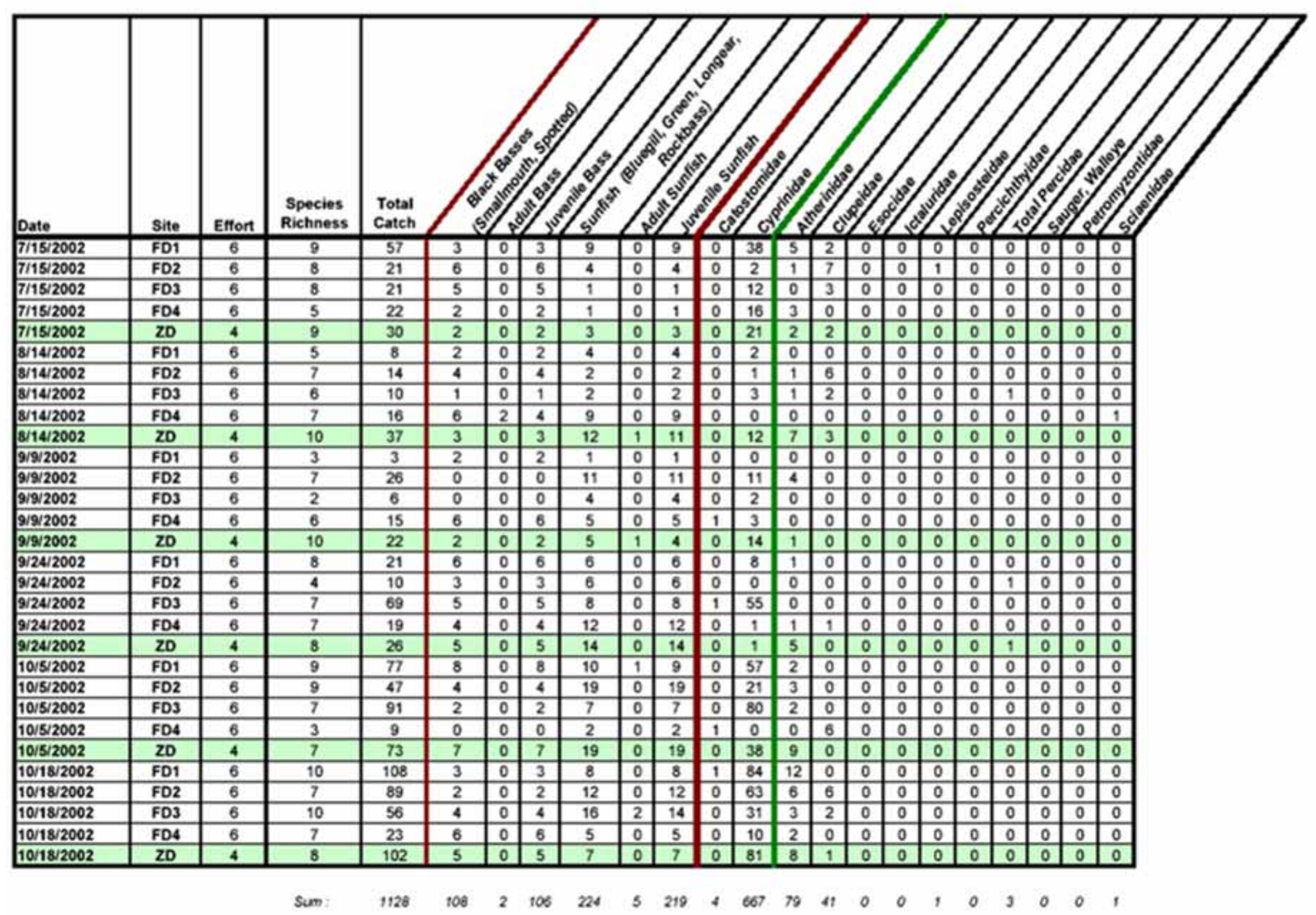


Appendix 5 : High Quality Reference Site Collection Totals - 2002 Day Sampling

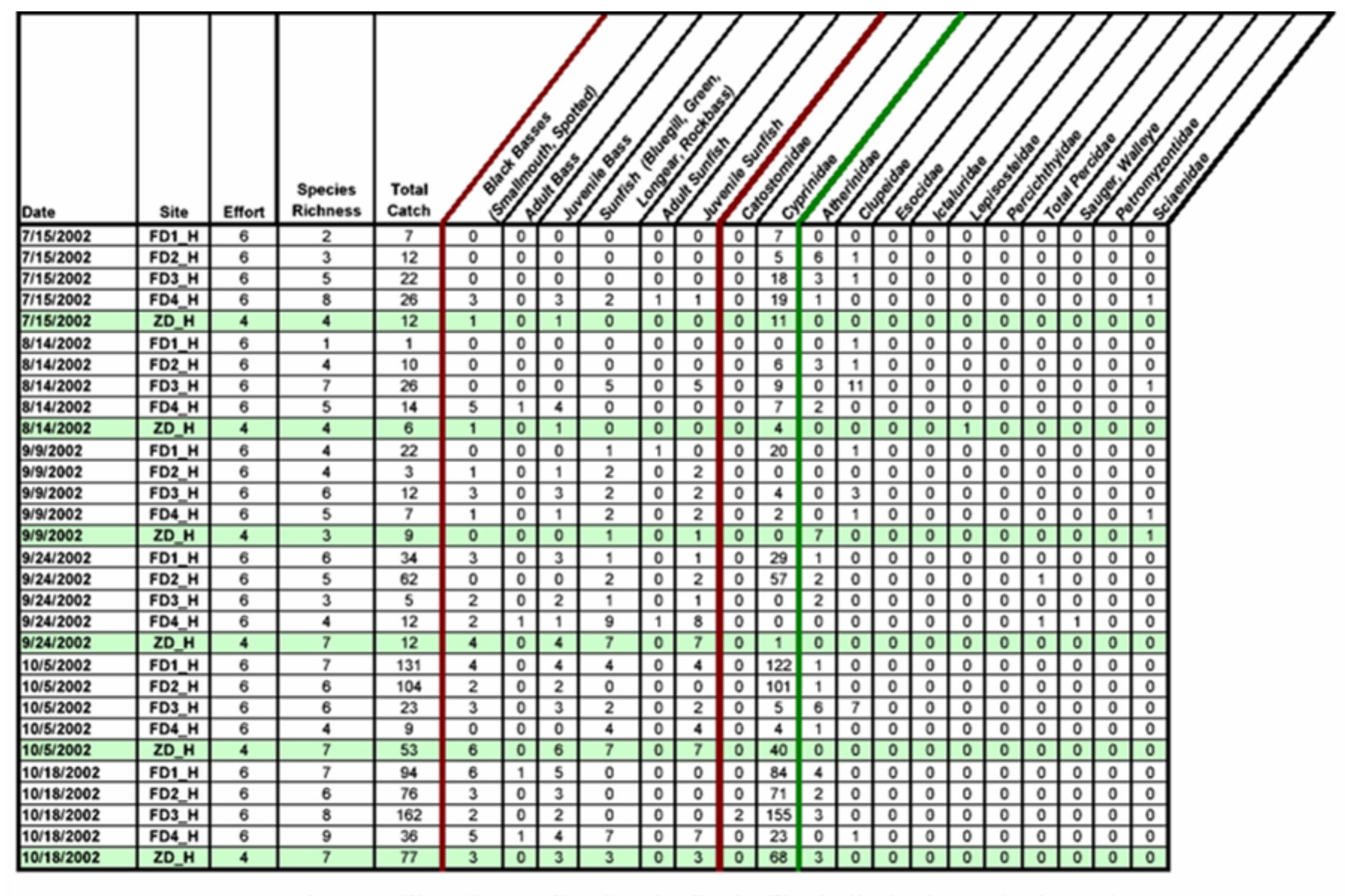

1079

60

$56 \quad 6$

50

$\begin{array}{lllll}872 & 48 & 28 & 0\end{array}$

1

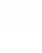


Appendix 6 : Low Quality Reference Site Collection Totals - 2002 Day Sampling

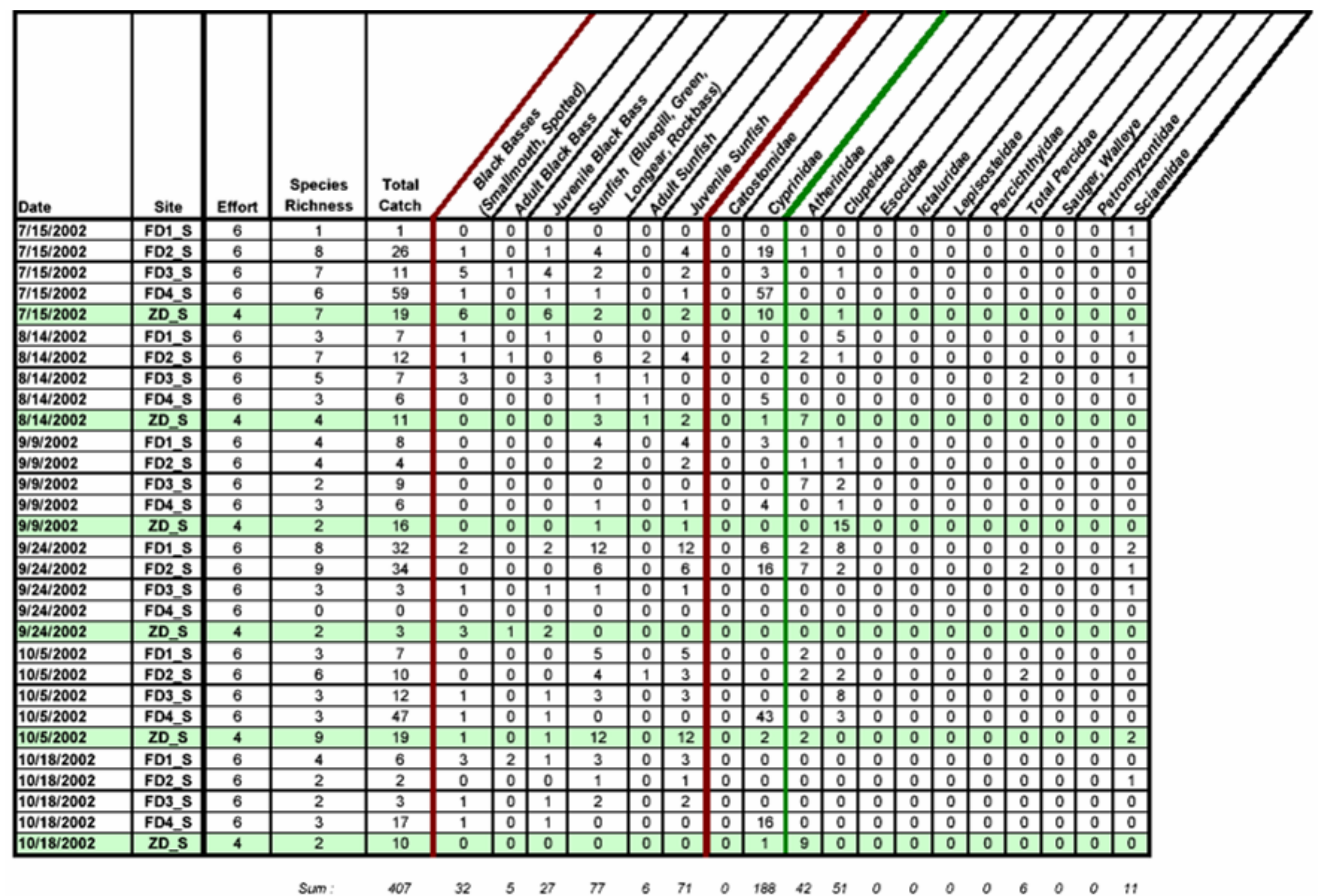


Appendix 7 : Artificial Structure Collection Totals - 2003 Day Sampling

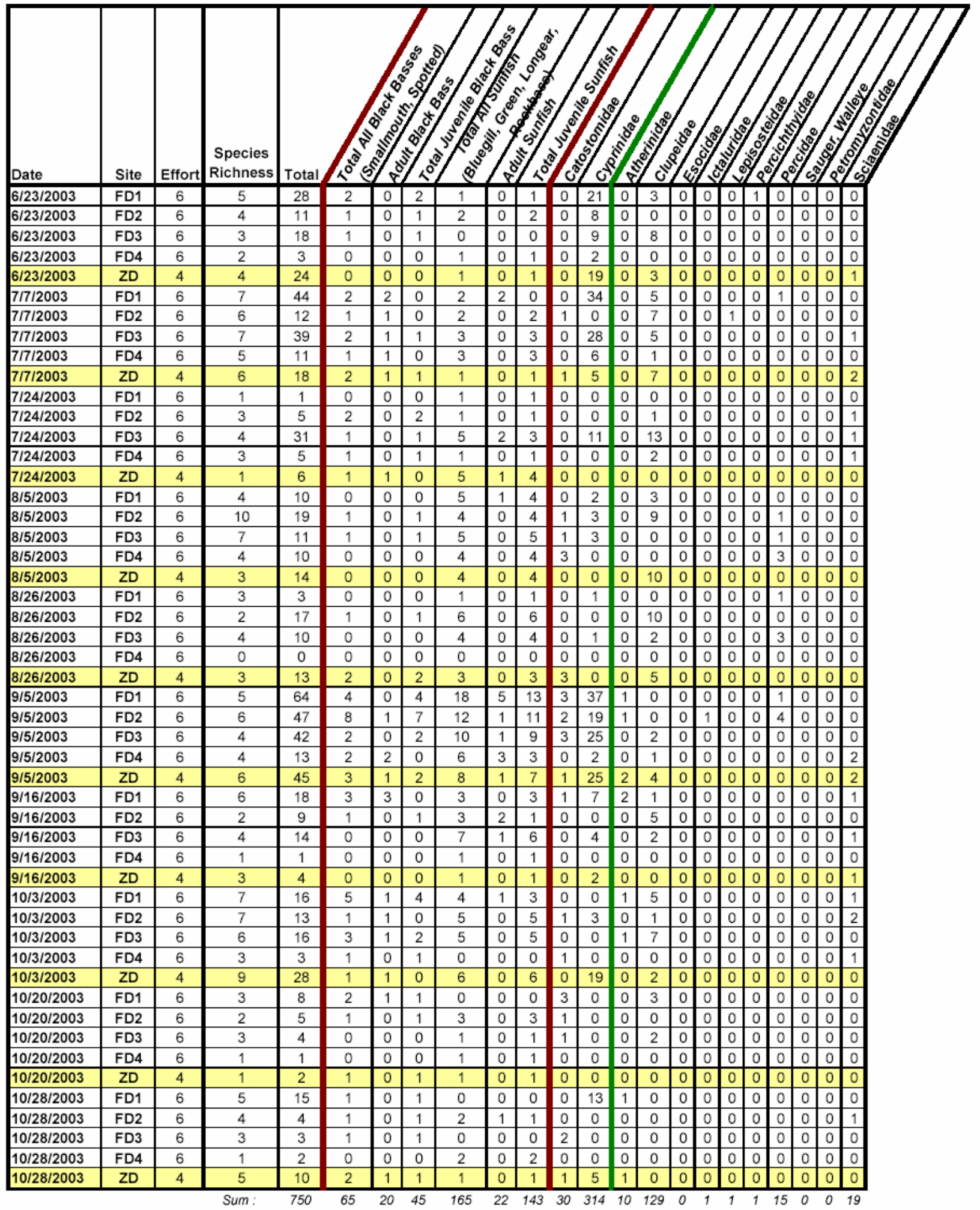


Appendix 8 : High Quality Reference Site Collection Totals - 2003 Day Sampling

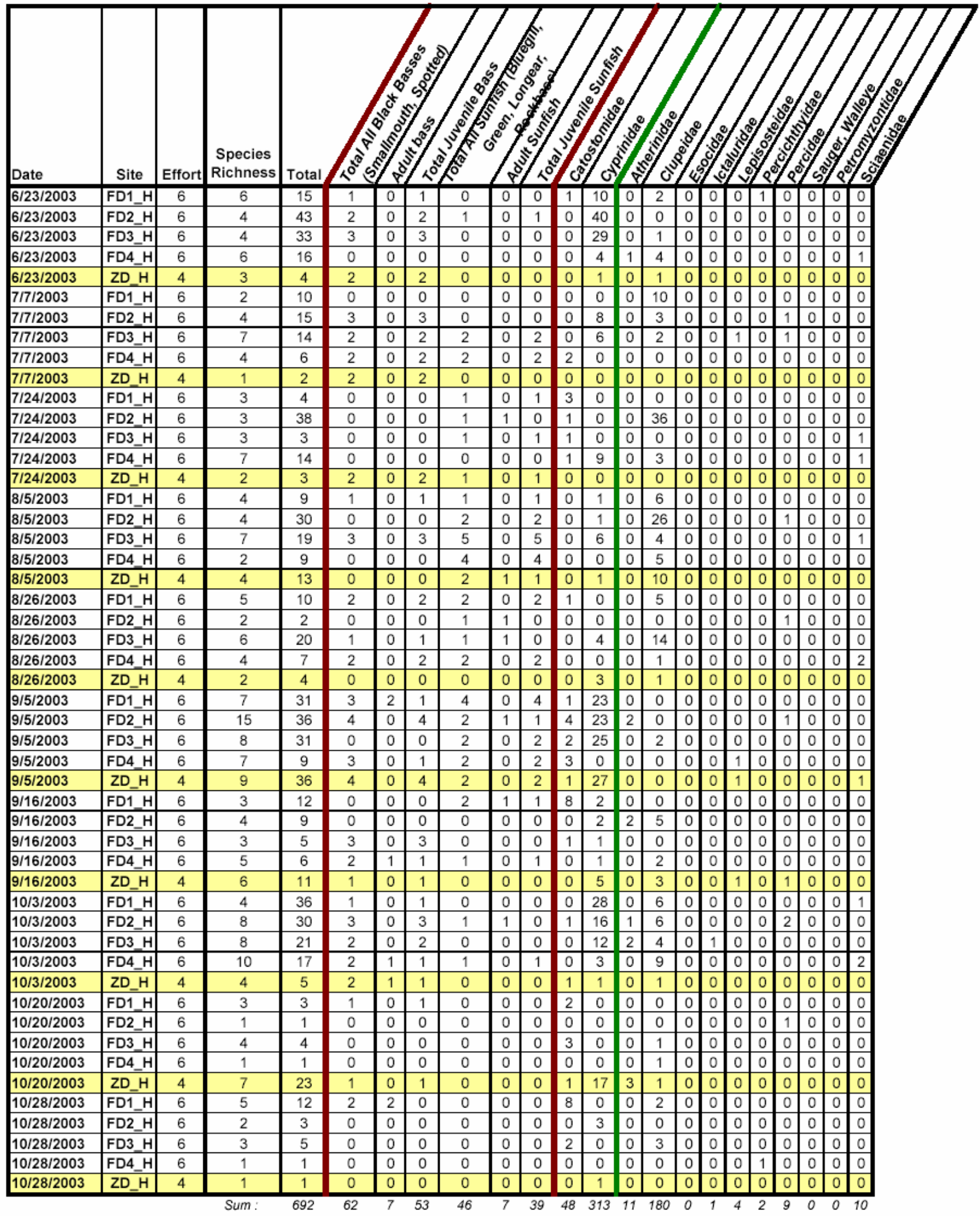


Appendix 9 : Low Quality Reference Site Collection Totals - 2003 Day Sampling

\begin{tabular}{|c|c|c|c|c|c|c|c|c|c|c|c|c|c|c|c|c|c|c|c|c|}
\hline Date & Site & Effort & $\begin{array}{l}\text { Species } \\
\text { Richness }\end{array}$ & & & & & & & & & & & & & & & & & \\
\hline $6 / 23 / 2003$ & FD1_S & 6 & 2 & 8 & 0 & 0 & 0 & 0 & 0 & 0 & 0 & 0 & 0 & 7 & 0 & \begin{tabular}{c|c}
0 & 0
\end{tabular} & $\begin{array}{ll}0 \\
0\end{array}$ & \begin{tabular}{|l|l|}
0 & 0 \\
\end{tabular} & 10 & 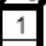 \\
\hline $6 / 23 / 2003$ & FD2_S & 6 & 5 & 10 & 2 & 0 & 2 & 1 & 1 & 0 & 0 & 4 & 0 & 3 & 0 & \begin{tabular}{l|l}
0 & 0 \\
0
\end{tabular} & $\begin{array}{l}0 \\
0\end{array}$ & \begin{tabular}{|l|l|}
0 & 0 \\
\end{tabular} & 0 & 0 \\
\hline $6 / 23 / 2003$ & FD3_S & 6 & 4 & 6 & 1 & 0 & 1 & 1 & 0 & 1 & 0 & 2 & 0 & 2 & 0 & \begin{tabular}{l|l}
0 & 0 \\
0
\end{tabular} & $\begin{array}{l}0 \\
0\end{array}$ & \begin{tabular}{|l|l|}
0 & 0 \\
\end{tabular} & 0 & 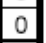 \\
\hline $6 / 23 / 2003$ & FD4_S & 6 & 3 & 11 & 1 & 0 & 1 & 0 & 0 & 0 & 0 & 9 & 0 & 1 & 0 & \begin{tabular}{l|l}
0 & 0 \\
\end{tabular} & $\begin{array}{l}0 \\
0\end{array}$ & \begin{tabular}{|l|l|}
0 & 0 \\
\end{tabular} & 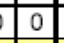 & 0 \\
\hline $6 / 23 / 2003$ & ZD_s & 4 & 4 & 12 & 1 & 1 & 0 & 1 & 1 & 0 & 0 & 6 & 0 & 4 & 0 & & $\begin{array}{l}0 \\
0\end{array}$ & \begin{tabular}{|l|l}
0 & 0 \\
\end{tabular} & 0 & 0 \\
\hline $717 / 2003$ & FD1_S & 6 & 6 & 7 & 0 & 0 & 0 & 2 & 1 & 1 & 0 & 2 & 0 & 2 & 0 & \begin{tabular}{l|l}
0 & 0 \\
\end{tabular} & $\begin{array}{l}0 \\
0\end{array}$ & \begin{tabular}{|l|l|}
1 & 0 \\
\end{tabular} & \begin{tabular}{|l|l|} 
& 0 \\
\end{tabular} & 0 \\
\hline $7 / 7 / 2003$ & FD2_S & 6 & 3 & 9 & 1 & 0 & 1 & 0 & 0 & 0 & 0 & 0 & 0 & 7 & 0 & 0 & $\begin{array}{l}0 \\
0\end{array}$ & \begin{tabular}{|l|l}
0 & 0 \\
\end{tabular} & \begin{tabular}{|l|} 
\\
\end{tabular} & \\
\hline $717 / 2003$ & FD3_S & 6 & 3 & 7 & 0 & 0 & 0 & 1 & 0 & 1 & 0 & 0 & 0 & 5 & 0 & \begin{tabular}{l|l}
1 & $c$ \\
\end{tabular} & \begin{tabular}{l|l}
0 & 0 \\
\end{tabular} & \begin{tabular}{|l|l|}
0 & 0 \\
\end{tabular} & 0 & 0 \\
\hline $717 / 2003$ & FD4_S & 6 & 1 & 5 & 0 & 0 & 0 & 0 & 0 & 0 & 0 & 0 & 0 & 5 & 0 & 0 & $\begin{array}{l}0 \\
0\end{array}$ & \begin{tabular}{|l|l}
0 & 0 \\
\end{tabular} & 0 & 0 \\
\hline $717 / 2003$ & ZD_s & 4 & 4 & 4 & 1 & 0 & 1 & 0 & 0 & 0 & 1 & 0 & 0 & 1 & 0 & 0 & \begin{tabular}{l|l}
0 & 0 \\
\end{tabular} & \begin{tabular}{|l|l|}
0 & 0 \\
\end{tabular} & 0 & 1 \\
\hline $7 / 24 / 2003$ & FD1_S & 6 & 2 & 2 & 0 & 0 & 0 & 1 & 0 & 1 & 0 & 0 & 0 & 0 & 0 & 0 & $\begin{array}{l}0 \\
0\end{array}$ & \begin{tabular}{|l|l|}
0 & 0 \\
\end{tabular} & 0 & 1 \\
\hline $7124 / 2003$ & FD2_S & 6 & 6 & 6 & 1 & 1 & 0 & 1 & 1 & 0 & 3 & 0 & 0 & 0 & 0 & 0 & $\begin{array}{l}0 \\
0\end{array}$ & \begin{tabular}{|l|l|}
1 & 0 \\
\end{tabular} & 0 & 1 \\
\hline $7 / 24 / 2003$ & FD3_S & 6 & 2 & 2 & 1 & 0 & 1 & 0 & 0 & 0 & 0 & 0 & 0 & 1 & 0 & 0 & \begin{tabular}{l|l}
0 & 0 \\
\end{tabular} & \begin{tabular}{|l|l|}
0 & 0 \\
\end{tabular} & 0 & 0 \\
\hline $7 / 24 / 2003$ & FD4_S & 6 & 1 & 1 & 0 & 0 & 0 & 0 & 0 & 0 & 1 & 0 & 0 & 0 & 0 & 0 & \begin{tabular}{l|l}
0 & 0 \\
\end{tabular} & \begin{tabular}{|l|l|}
0 & 0 \\
\end{tabular} & 0 & 0 \\
\hline $7 / 24 / 2003$ & ZD_s & 4 & 4 & 4 & 2 & 0 & 2 & 1 & 1 & 0 & 0 & 0 & 0 & 0 & 0 & 0 & $\begin{array}{l}0 \\
0\end{array}$ & \begin{tabular}{|l|l|}
0 & 0 \\
\end{tabular} & 0 & 1 \\
\hline $8 / 5 / 2003$ & FD1_S & 6 & 4 & 7 & 2 & 0 & 2 & 1 & 0 & 1 & 0 & 0 & 0 & 1 & 0 & 0 & 0 & \begin{tabular}{|l|l|}
3 & 0 \\
\end{tabular} & 0 & 0 \\
\hline $8 / 5 / 2003$ & FD2_S & 6 & 3 & 4 & 1 & 0 & 1 & 0 & 0 & 0 & 0 & 0 & 0 & 1 & 0 & 0 & $\begin{array}{l}0 \\
0\end{array}$ & \begin{tabular}{|l|l|}
2 & 0 \\
\end{tabular} & $0 \mid$ & 0 \\
\hline $8 / 5 / 2003$ & FD3_S & 6 & 2 & 2 & 0 & 0 & 0 & 0 & 0 & 0 & 0 & 0 & 0 & 1 & 0 & 0 & \begin{tabular}{l|l}
0 & 0 \\
\end{tabular} & \begin{tabular}{|l|l|}
1 & 0 \\
\end{tabular} & 0 & 0 \\
\hline $8 / 5 / 2003$ & FD4_S & 6 & 2 & 3 & 2 & 1 & 1 & 0 & 0 & 0 & 0 & 0 & 0 & 1 & 0 & \begin{tabular}{l|l}
0 & 0 \\
\end{tabular} & \begin{tabular}{l|l}
0 & 0 \\
\end{tabular} & \begin{tabular}{|l|l|}
0 & 0 \\
\end{tabular} & $0 \mid$ & 0 \\
\hline $8 / 5 / 2003$ & ZD_s & 4 & 2 & 2 & 1 & 0 & 1 & 1 & 0 & 1 & 0 & 0 & 0 & 0 & 0 & \begin{tabular}{l|l}
0 & 0 \\
0
\end{tabular} & \begin{tabular}{l|l}
0 & 0 \\
\end{tabular} & \begin{tabular}{|l|l|}
0 & 0 \\
\end{tabular} & 0 & 0 \\
\hline $8 / 26 / 2003$ & FD1_S & 6 & 1 & 1 & 1 & 0 & 1 & 0 & 0 & 0 & 0 & 0 & 0 & 0 & 0 & 0 & \begin{tabular}{l|l}
0 \\
0
\end{tabular} & \begin{tabular}{|l|l}
0 & 0 \\
\end{tabular} & 0 & 0 \\
\hline $8 / 26 / 2003$ & FD2_S & 6 & 3 & 4 & 1 & 0 & 1 & 0 & 0 & 0 & 0 & 0 & 0 & 2 & 0 & 0 & \begin{tabular}{l|l}
0 & 0 \\
\end{tabular} & \begin{tabular}{|l|l|}
1 & 0 \\
\end{tabular} & 0 & 0 \\
\hline $8 / 26 / 2003$ & FD3_S & 6 & 3 & 3 & 1 & 0 & 1 & 1 & 1 & 0 & 0 & 0 & 0 & 0 & 0 & 0 & \begin{tabular}{l|l}
0 & 0 \\
\end{tabular} & \begin{tabular}{|l|l|}
0 & 0 \\
\end{tabular} & $0 \mid$ & 1 \\
\hline $8 / 26 / 2003$ & FD4_S & 6 & 4 & 5 & 1 & 1 & 1 & 4 & 1 & 3 & 0 & 0 & 0 & 0 & 0 & \begin{tabular}{l|l}
0 & 0 \\
\end{tabular} & $\begin{array}{l}0 \\
0\end{array}$ & \begin{tabular}{|l|l|}
0 & 0 \\
\end{tabular} & 0 & 0 \\
\hline $8 / 26 / 2003$ & ZD_s & 4 & 2 & 2 & 1 & 1 & 0 & 1 & 0 & 1 & 0 & 0 & 0 & 0 & 0 & \begin{tabular}{l|l}
0 & $c$ \\
0
\end{tabular} & $\begin{array}{l}0 \\
0\end{array}$ & \begin{tabular}{|l|l|}
0 & 0 \\
\end{tabular} & $0 \mid$ & 0 \\
\hline 9/5/2003 & FD1_S & 6 & 2 & 3 & 2 & 1 & 1 & 0 & 0 & 0 & 0 & 0 & 0 & 0 & 0 & 0 & $\begin{array}{l}0 \\
0\end{array}$ & \begin{tabular}{|l|l|}
1 & 1 \\
\end{tabular} & 10 & 0 \\
\hline 9/5/2003 & FD2_S & 6 & 5 & 10 & 4 & 0 & 4 & 3 & 0 & 3 & 0 & 3 & 0 & 0 & 0 & \begin{tabular}{l|l}
0 & 0 \\
0
\end{tabular} & \begin{tabular}{l|l}
0 & 0 \\
\end{tabular} & \begin{tabular}{|l|l}
0 & 0 \\
\end{tabular} & $0 \mid$ & 0 \\
\hline 9/5/2003 & FD3_S & 6 & 6 & 11 & 3 & 0 & 3 & 3 & 0 & 3 & 0 & 2 & 0 & 1 & 0 & \begin{tabular}{c|c}
0 & 0 \\
\end{tabular} & \begin{tabular}{l|l}
0 & 0 \\
\end{tabular} & \begin{tabular}{|l|l|}
0 & 0 \\
\end{tabular} & 0 & 2 \\
\hline 9/5/2003 & FD4_S & 6 & 5 & 5 & 0 & 0 & 0 & 0 & 0 & 0 & 3 & 0 & 0 & 0 & 0 & 0 & \begin{tabular}{l|l}
1 & 0 \\
\end{tabular} & \begin{tabular}{|l|l|}
1 & 1 \\
\end{tabular} & 10 & 0 \\
\hline $9 / 5 / 2003$ & ZD_S & 4 & 5 & 8 & 0 & 0 & 0 & 2 & 0 & 2 & 1 & 5 & 0 & 0 & 0 & \begin{tabular}{l|l}
0 & 0 \\
\end{tabular} & 0 & \begin{tabular}{|l|l|}
0 & 0 \\
\end{tabular} & 0 & 0 \\
\hline 9/16/2003 & FD1_S & 6 & 4 & 4 & 1 & 0 & 1 & 3 & 2 & 1 & 0 & 0 & 0 & 0 & 0 & \begin{tabular}{l|l}
0 & 0 \\
\end{tabular} & \begin{tabular}{l|l}
0 & 0 \\
\end{tabular} & \begin{tabular}{|l|l|}
0 & 0 \\
\end{tabular} & $0 \mid$ & 0 \\
\hline 9/16/2003 & FD2_S & 6 & 4 & 5 & 1 & 1 & 0 & 3 & 0 & 3 & 0 & 0 & 0 & 0 & 0 & \begin{tabular}{l|l}
0 & 0 \\
\end{tabular} & $\begin{array}{l}0 \\
0\end{array}$ & \begin{tabular}{|l|l|}
0 & 0 \\
\end{tabular} & 0 & \\
\hline 9/16/2003 & FD3_S & 6 & 1 & 2 & 0 & 0 & 0 & 2 & 0 & 2 & 0 & 0 & 0 & 0 & 0 & \begin{tabular}{l|c}
0 & $c$ \\
\end{tabular} & $\begin{array}{l}0 \\
0\end{array}$ & \begin{tabular}{|l|l|}
0 & 0 \\
\end{tabular} & 0 & 0 \\
\hline 9/16/2003 & FD4_S & 6 & 1 & 1 & 0 & 0 & 0 & 0 & 0 & 0 & 0 & 0 & 0 & 1 & 0 & 00 & $\begin{array}{l}0 \\
0\end{array}$ & \begin{tabular}{|l|l|}
0 & 0 \\
\end{tabular} & 0 & 0 \\
\hline 9/16/2003 & ZD_s & 4 & 6 & 11 & 3 & 1 & 2 & 4 & 1 & 3 & 0 & 3 & 0 & 1 & $0 \mid$ & \begin{tabular}{l|l}
0 \\
0
\end{tabular} & $\begin{array}{l}0 \\
0\end{array}$ & \begin{tabular}{|l|l|}
0 & 0 \\
\end{tabular} & $0 \mid$ & 0 \\
\hline $10 / 3 / 2003$ & FD1_S & 6 & 2 & 2 & 0 & 0 & 0 & 1 & 1 & 0 & 0 & 0 & 0 & 0 & 0 & \begin{tabular}{l|l}
0 & $c$ \\
\end{tabular} & $\begin{array}{ll}0 & 0 \\
\end{array}$ & \begin{tabular}{|l|l|}
0 & 0 \\
\end{tabular} & $0 \mid$ & 1 \\
\hline 10/3/2003 & FD2_S & 6 & 5 & 8 & 3 & 0 & 3 & 4 & 2 & 2 & 0 & 0 & 0 & 1 & 0 & \begin{tabular}{|l|l}
0 & 0 \\
\end{tabular} & \begin{tabular}{l|l}
0 & 0 \\
\end{tabular} & \begin{tabular}{|l|l|}
0 & 0 \\
\end{tabular} & \begin{tabular}{l|l|}
0 & 0 \\
\end{tabular} & 0 \\
\hline $10 / 3 / 2003$ & FD3_S & 6 & 1 & 3 & 0 & 0 & 0 & 0 & 0 & 0 & 0 & 0 & 0 & 0 & 0 & \begin{tabular}{l|l}
0 \\
\end{tabular} & $\begin{array}{ll}0 & 0 \\
\end{array}$ & \begin{tabular}{|l|l|}
0 & 0 \\
\end{tabular} & 0 & 3 \\
\hline $10 / 3 / 2003$ & FD4_S & 6 & 2 & 5 & 0 & 0 & 0 & 0 & 0 & 0 & 1 & 3 & 0 & 0 & 0 & $0 \mid$ & \begin{tabular}{l|l}
0 & 0 \\
\end{tabular} & \begin{tabular}{|l|l}
0 & 0 \\
\end{tabular} & \begin{tabular}{ll|}
0 & 0 \\
\end{tabular} & 1 \\
\hline $10 / 3 / 2003$ & ZD_s & 4 & 0 & 0 & 0 & 0 & 0 & 0 & 0 & 0 & 0 & 0 & 0 & 0 & 0 & \begin{tabular}{|l|l}
0 & \\
\end{tabular} & $\begin{array}{l}0 \\
0\end{array}$ & \begin{tabular}{|l|l|}
0 & 0 \\
\end{tabular} & $\begin{array}{l}0 \\
0\end{array}$ & 0 \\
\hline $10 / 20 / 2003$ & FD1_S & 6 & 1 & 1 & 0 & 0 & 0 & 1 & 1 & 0 & 0 & 0 & 0 & 0 & 0 & \begin{tabular}{l|l}
0 & \\
\end{tabular} & $\begin{array}{l}0 \\
0\end{array}$ & \begin{tabular}{|l|l}
0 & 0 \\
\end{tabular} & $\begin{array}{l}0 \\
0\end{array}$ & 0 \\
\hline $10 / 20 / 2003$ & FD2_S & 6 & 2 & 4 & 2 & 0 & 2 & 1 & 1 & 0 & 0 & 0 & 0 & 0 & 0 & \begin{tabular}{l|l}
0 \\
\end{tabular} & \begin{tabular}{l|l}
0 & 0
\end{tabular} & \begin{tabular}{|l|l|}
0 & 0 \\
\end{tabular} & $\begin{array}{lll}0 & 0\end{array}$ & 0 \\
\hline $10 / 20 / 2003$ & FD3_S & 6 & 2 & 2 & 0 & 0 & 0 & 2 & 1 & 1 & 0 & 0 & 0 & 0 & 0 & $0 \mid$ & \begin{tabular}{l|l}
0 & 0 \\
0
\end{tabular} & \begin{tabular}{|l|l|}
0 & 0 \\
\end{tabular} & $\begin{array}{ll}0 & 0 \\
0\end{array}$ & 0 \\
\hline $10 / 20 / 2003$ & FD4_S & 6 & 2 & 14 & 0 & 0 & 0 & 0 & 0 & 0 & 0 & 14 & 0 & 0 & 0 & \begin{tabular}{|l|l}
0 & \\
\end{tabular} & $\begin{array}{ll}0 & 0 \\
\end{array}$ & 0 & 0 & 0 \\
\hline $10 / 20 / 2003$ & ZD_s & 4 & 2 & 3 & 0 & 0 & 0 & 2 & 2 & 0 & 0 & 0 & 0 & 1 & 0 & \begin{tabular}{l|l}
0 \\
\end{tabular} & 0 & \begin{tabular}{|l|l|}
0 & 0 \\
\end{tabular} & 0 & 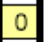 \\
\hline $10 / 28 / 2003$ & FD1_s & 6 & 1 & 1 & 0 & 0 & 0 & 1 & 1 & 0 & 0 & 0 & 0 & 0 & 0 & \begin{tabular}{|l|l|l|}
0 & \\
\end{tabular} & 0 & \begin{tabular}{|l|l|}
0 & 0 \\
\end{tabular} & 0 & 0 \\
\hline $10 / 28 / 2003$ & FD2_S & 6 & 1 & 2 & 0 & 0 & 0 & 0 & 0 & 0 & 0 & 0 & 0 & 2 & 0 & 0 & \begin{tabular}{l|l}
0 & 0 \\
\end{tabular} & 0 & 0 & 0 \\
\hline $10 / 28 / 2003$ & FD3_S & 6 & 0 & 0 & 0 & 0 & 0 & 0 & 0 & 0 & 0 & 0 & 0 & 0 & 0 & $0 \mid$ & $\begin{array}{ll}0 & 0 \\
\end{array}$ & \begin{tabular}{|l|l}
0 & 0 \\
\end{tabular} & 0 & 0 \\
\hline $10 / 28 / 2003$ & FD4_S & 6 & 3 & 10 & 0 & 0 & 0 & 0 & 0 & 0 & 0 & 10 & 0 & 0 & 0 & 0 & $\begin{array}{ll}0 & 0 \\
\end{array}$ & \begin{tabular}{|l|l|}
0 & 0 \\
\end{tabular} & 0 & 0 \\
\hline $10 / 29 / 2003$ & ZD_s & 4 & 0 & 0 & 0 & 0 & 0 & 0 & 0 & 0 & 0 & 0 & 0 & 0 & 0 & \begin{tabular}{|l|l|l}
0 & \\
\end{tabular} & $\begin{array}{l}0 \\
0\end{array}$ & \begin{tabular}{|l|l|}
0 & 0 \\
\end{tabular} & 0 & 0 \\
\hline
\end{tabular}


Appendix 10 : Artificial Structure Collection Totals - 2003 Night Sampling

\begin{tabular}{|c|c|c|c|c|c|c|c|c|c|c|c|c|c|c|c|c|c|c|c|c|c|c|}
\hline Date & Site & Effort & $\begin{array}{c}\text { Species } \\
\text { Richness }\end{array}$ & $\begin{array}{r}\text { Total } \\
\text { Catch } \\
\end{array}$ & & & & & & & & & & & & & & & & & & \\
\hline 6/11/2003 & FD1 & 6 & 8 & 54 & 0 & 0 & 0 & 12 & 5 & 7 & 2 & 37 & 0 & 1 & $\overline{0}$ & 0 & 0 & 0 & 0 & $\overline{0}$ & \begin{tabular}{l|l}
0 & \\
\end{tabular} & 2 \\
\hline $6 / 11 / 2003$ & FD2 & 6 & 11 & 35 & 2 & 0 & 2 & 20 & 3 & 17 & 1 & 9 & 0 & 0 & 0 & 1 & 0 & 1 & 0 & 0 & 0 & 1 \\
\hline 6/11/2003 & FD3 & 6 & 9 & 47 & 6 & 4 & 2 & 9 & 5 & 4 & 4 & 24 & 0 & 3 & 0 & 0 & 0 & 0 & 0 & 0 & 0 & 1 \\
\hline $6 / 11 / 2003$ & FD4 & 6 & 9 & 15 & 2 & 0 & 2 & 3 & 0 & 3 & 3 & 4 & 0 & 1 & 0 & 0 & 0 & 1 & 1 & 1 & 0 & 0 \\
\hline 6/11/2003 & ZD & 4 & 6 & 23 & 2 & 0 & 2 & 6 & 0 & 6 & 0 & 14 & 0 & 1 & 0 & 0 & 0 & 0 & 0 & 0 & 0 & 0 \\
\hline $7 / 13 / 2003$ & FD1 & 6 & 15 & 70 & 8 & 2 & 6 & 10 & 1 & 9 & 4 & 40 & 0 & 6 & 0 & 0 & 1 & 0 & 1 & 1 & 0 & 0 \\
\hline $7 / 13 / 2003$ & FD2 & 6 & 13 & 55 & 4 & 1 & 3 & 8 & 0 & 8 & 3 & 29 & 0 & 7 & 0 & 0 & 0 & 1 & 3 & 2 & 0 & 0 \\
\hline 7/13/2003 & FD3 & 6 & 12 & 47 & 5 & 0 & 5 & 12 & 0 & 12 & 4 & 20 & 0 & 5 & 0 & 0 & 0 & 0 & 1 & 1 & 0 & 0 \\
\hline $7 / 13 / 2003$ & FD4 & 6 & 13 & 49 & 4 & 0 & 4 & 4 & 1 & 3 & 3 & 35 & 0 & 1 & 0 & 0 & 1 & 0 & 1 & 1 & 0 & 0 \\
\hline $7 / 13 / 2003$ & ZD & 4 & 9 & 30 & 1 & 0 & 1 & 6 & 3 & 3 & 0 & 15 & 0 & 6 & 0 & 0 & 0 & 0 & 2 & 2 & 0 & 0 \\
\hline 8/11/2003 & FD1 & 6 & 11 & 32 & 1 & 0 & 1 & 8 & 1 & 7 & 5 & 6 & 0 & 0 & 0 & 0 & 0 & 0 & 3 & 3 & 0 & 9 \\
\hline $8 / 11 / 2003$ & FD2 & 6 & 12 & 51 & 5 & 1 & 4 & 14 & 2 & 12 & 5 & 10 & 1 & 0 & 0 & 0 & 0 & 2 & 1 & 0 & \begin{tabular}{l|l}
0 & 1
\end{tabular} & 13 \\
\hline 8/11/2003 & FD3 & 6 & 11 & 50 & 0 & 0 & 0 & 14 & 1 & 13 & 7 & 19 & 0 & 0 & 0 & 1 & 0 & 3 & 0 & 0 & 0 & 6 \\
\hline 8/11/2003 & FD4 & 6 & 5 & 12 & 2 & 1 & 1 & 2 & 0 & 2 & 0 & 2 & 0 & 0 & 0 & 0 & 0 & 1 & 0 & 0 & 0 & 5 \\
\hline $8 / 11 / 2003$ & ZD & 4 & 10 & 29 & 3 & 0 & 3 & 15 & 0 & 15 & 0 & 1 & 0 & 0 & 0 & 0 & 1 & 0 & 1 & 1 & $0 \mid 8$ & 8 \\
\hline 10/1/2003 & FD1 & 6 & 13 & 53 & 4 & 1 & 3 & 12 & 0 & 12 & 0 & 34 & 1 & 0 & 0 & 0 & 0 & 0 & 2 & 2 & 0 & 0 \\
\hline 10/1/2003 & FD2 & 6 & 10 & 40 & 6 & 3 & 3 & 22 & 0 & 22 & 1 & 10 & 0 & 0 & 0 & 0 & 0 & 0 & 1 & 0 & 0 & 0 \\
\hline 10/1/2003 & FD3 & 6 & 10 & 25 & 8 & 0 & 8 & 7 & 0 & 7 & 3 & 6 & 0 & 0 & 0 & 0 & 0 & 0 & 1 & 1 & 0 & 0 \\
\hline 10/1/2003 & FD4 & 6 & 11 & 35 & 1 & 1 & 0 & 14 & 2 & 12 & 0 & 16 & 0 & 3 & 0 & 0 & 0 & 0 & 1 & 1 & 0 & 0 \\
\hline 10/1/2003 & ZD & 4 & 9 & 20 & 4 & 1 & 3 & 10 & 0 & 10 & 1 & 4 & 0 & 0 & 0 & 0 & 0 & 0 & 0 & 0 & 10 & 0 \\
\hline 10/29/2003 & FD1 & 6 & 10 & 19 & 3 & 0 & 3 & 5 & 0 & 5 & 5 & 4 & 0 & 1 & 0 & 0 & 0 & 0 & 1 & 1 & 0 & 0 \\
\hline 10/29/2003 & FD2 & 6 & 8 & 13 & 1 & 0 & 1 & 4 & 0 & 4 & 6 & 1 & 0 & 0 & 0 & 0 & 0 & 0 & 1 & 1 & 0 & 0 \\
\hline 10/29/2003 & FD3 & 6 & 9 & 20 & 1 & 0 & 1 & 5 & 0 & 5 & 14 & 0 & 0 & 0 & 0 & 0 & 0 & 0 & 0 & 0 & 0 & 0 \\
\hline $10 / 29 / 2003$ & FD4 & 6 & 9 & 12 & 4 & 0 & 4 & 4 & 1 & 3 & 0 & 1 & 0 & 0 & 0 & 0 & 0 & 1 & 1 & 1 & 0 & 1 \\
\hline 10/29/2003 & $\mathrm{ZD}$ & 4 & 7 & 12 & 1 & 1 & 0 & 5 & 0 & 5 & 2 & 2 & 0 & 0 & 0 & 0 & 0 & 1 & 0 & 0 & 0 & 1 \\
\hline
\end{tabular}




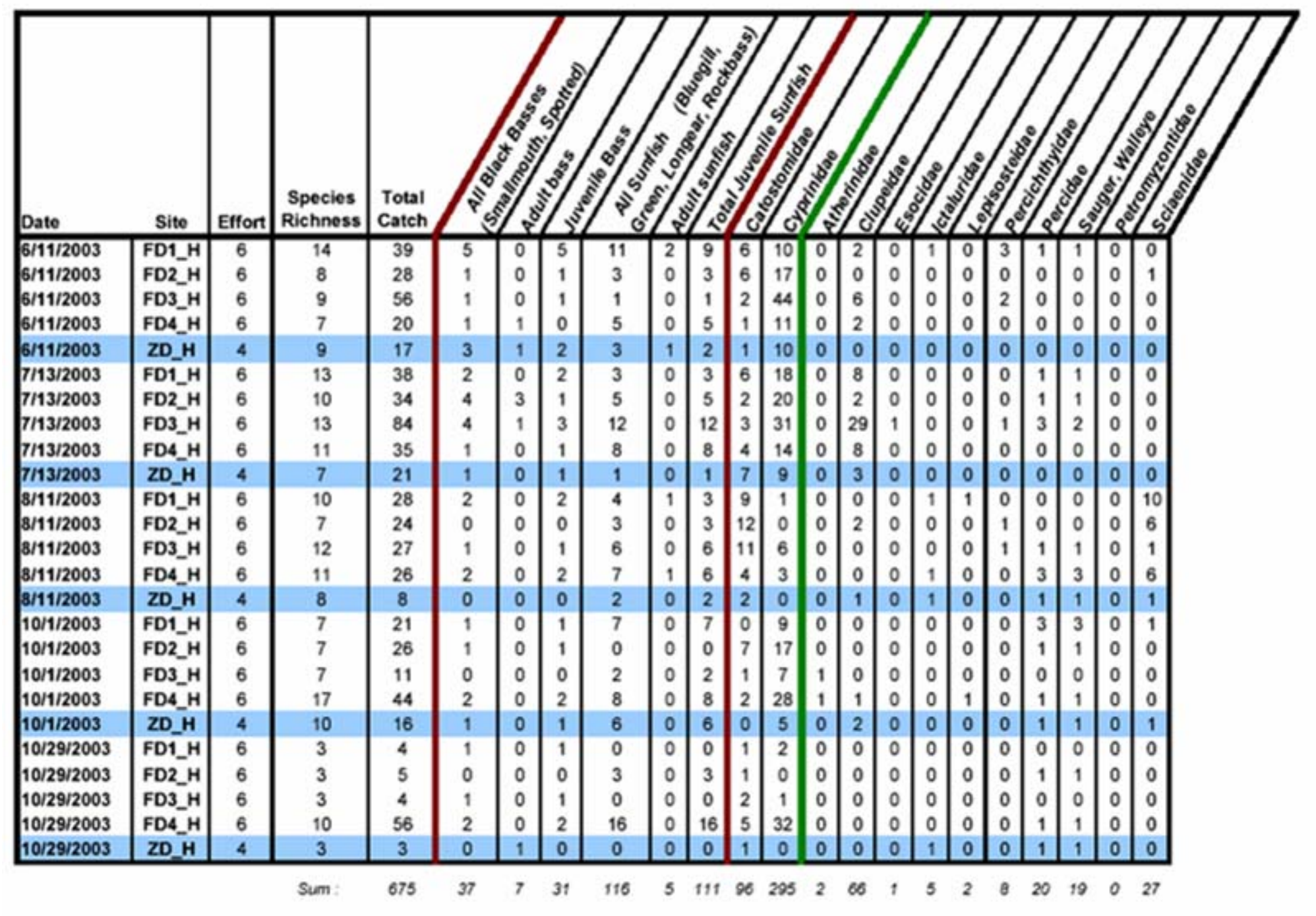


Appendix 12 : Low Quality Reference Site Collection Totals - 2003 Night Sampling

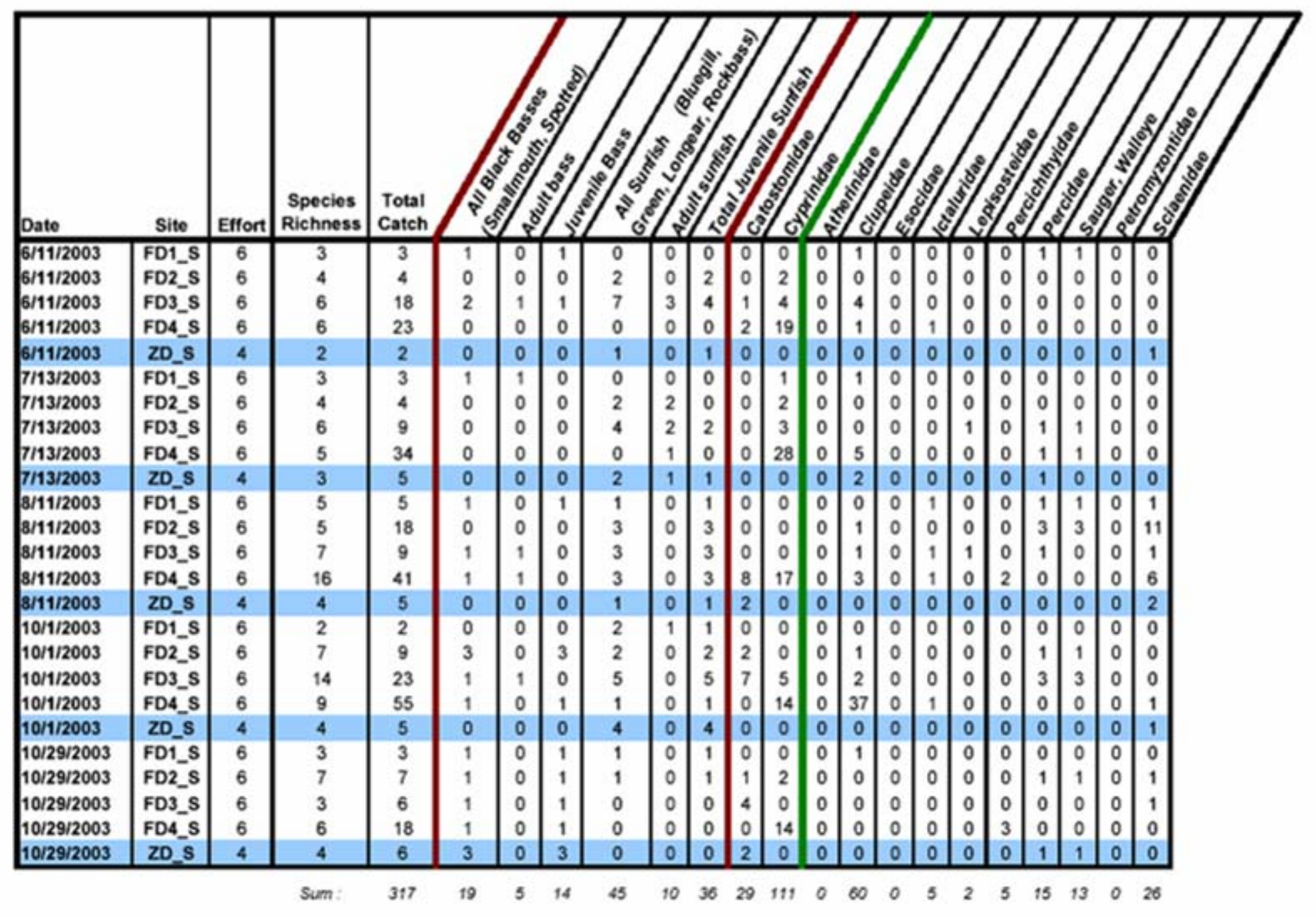




\section{Section Ten: Curriculum Vitae}




\section{Jennifer Titus}

1013 Ridgeway Avenue, Morgantown, West Virginia 26505

$304-291-5648$

e-mail: jtitus@hfti.com

Citizenship : United States

\section{Education}

West Virginia University

Morgantown, West Virginia 26506

Alfred University

Alfred, New York 14802

Monroe Community College

Rochester, New York 14692

Honeoye Falls - Lima High School

Honeoye Falls, New York 14472
Aug. 2002 - May 2004

M.S. Fisheries Resources

GPA : 3.62

Aug.1998 - May 2001

B.A. Environmental Science (Cum Laude)

GPA : 3.29

Aug. 1996 - Dec. 1998

A.A. Liberal Arts

GPA : 3.25

September 1992 - May 1996

High School Diploma

\section{Work Experience}

Graduate Research Assistant - West Virginia Univ. Wildlife and Fisheries, Morgantown, WV

- 08/200 2-04/2004

Dr. Kyle Hartman, 304-293-2941 ext 2494

- Salary: \$10,000 / year for 2 years \& 20 hours / week

In addition to my own project on the Kanawha River, I aided with other projects including larval fish collection, back-pack and boat electrofishing, and habitat surveys. I served as a main source of fish identification on different projects including a power plant effluent study of Dr. Hartman's.

Volunteer • West Virginia State Days, Blackwater Falls, WV

- 09/2003

Dan Cincotta, 304-637-0245

- Salary : Volunteer for 1 day \& 6 hours total

The West Virginia State Days are a series of activities sponsored by the WV DNR each fall. I assisted Dan Cincotta with children's stream session activities including bug collection, seining for fish and stream habitats. Dan was also on my Masters committee.

Sales • Towpath Bike Shop, Pittsford, NY

- 03/200 2-08/2002

Scott and Mike, 585-381-3080

- Salary : $\$ 5.75$ / hour \& 40 hours per week

For this position communication was crucial. I leaned to know your audience, exude confidence, and to work with other employees as a team. Prior to this position I knew little about bicycles. By the end I had some of the highest sales within the store demonstrating my ability to take on 
entirely new things and be successful.

Secretary $\bullet$ Mendon Chiropractic, Mendon, $N Y$

- 06/2002-08/2002

Brian Eder, DC, 585-624-4590

- Salary : \$7/hour \& 10 hours / week

I learned to professionally address patients in person and over the phone, make appointments and manage patient files.

Ski Race Coach and Crew • Bristol Mountain, Bristol, $N Y$

- 12/2001-03/2002

Steve Howie, 585-234-5000

- Salary : \$5.75 / hour \& 39 hours / week

I coached local high school race teams 1 to 2 nights per week. I also worked within a large race crew in set-up, maintenance, safety, and tear-down of race courses.

Biological Technician - George Washington and Jefferson National Forest SO, Roanoke, VA

- 08/2001 - 11/2001 Dawn Kirk, 540-291-2188 \& Cindy Huber, 540-265-5156

- Salary : \$9.75 / hour (GS 04) \& 40 hours / week

I independently managed a large water quality and macroinvertebrate database including entering and checking raw data, digitizing and displaying collections in GIS, and finishing with a usable final product with information for future users. In addition I assisted forest managers in field collection and other data management projects.

Volunteer • Brevard Zoo, Melbourne, FL

- 06/2001-08/2001

Betsy Hirchfeld

- Salary: Volunteer 1 day / week \& 9 hours / day

I designed enrichment activities and assisted in feeding and maintenance of resident animals under zookeeper Betsy. I learned animal training, diet composition, and animal health.

Hydrology Lab Technician • Alfred Univ. Environmental Science Dept., Alfred, NY

- 01/2001-05/2001

Michele Hluchy, 607-871-2838

- Salary : \$5.50 / hour \& 15 hours / week

I assured that lab equipment was prepared for use in addition to entering and working with collected data during a rainwater study. Michele Hluchy also was my undergraduate advisor.

SCUBA Employee • Mikes Aquatic Center, Watertown, $N Y$

- 06/1999-08/1999

Mike Washburn, 315-788-0973

- Salary : \$200/week + housing \& 40 hours / week

I worked for a small SCUBA dive shop filling SCUBA dive tanks, talking with customers about local dives, selling goods, and assisting with dive trips and training.

Student Intern • George Washington and Jefferson National Forest SO, Roanoke, VA

- 06/1999 - 08/1999 Dawn Kirk, 540-291-2188 \& Cindy Huber, 540-265-5156

- Salary : $\$ 300 / 2$ weeks \& 30 hours / week

I created a database for all flora and fauna recorded in Virginia caves as a preliminary listing for a state wide cave survey. I also assisted scientists in field work including pit-fall traps, stream 
electrofishing, and breeding bird surveys.

Junior Camp Counselor • Genesee Country Museum Nature Center, Mumford, NY

- 06/1998-08/1998

- Salary : \$125 / week \& 35 hours / week

I developed and presented educational activities while working at an environmental day camp for children ages 4 - 13.

Daytime Nanny • The Browns, Pittsford, NY

- 08/1996-06/1998

Marc and Sue Brown,585-248-0268

- Salary: \$7.50/hour \& 35 hours / week

I was responsible for two children including meals, after school activities, cleaning and errands.

\section{Training and Memberships}

- USFWS Fish Identification Course

National Conservation Training Center, Shepherdstown, WV

Nov. 2003

5-day course for West Virginia species identification

* Working at a Watershed Level

2-day watershed protection and restoration workshop

Feb 2003

$2^{\text {nd }}$ Annual Student Fisheries Colloquium, Tennessee Tech Univ.

Nov. 2002

American Fisheries Society ( Parent Society ) Member

Since 2002

American Fisheries Society West Virginia State Chapter Member

Since 2002

American Fisheries Society WVU Student Sub-Unit Member

Since 2002

Friends of Decker's Creek Watershed Group Member

Since 2003

Electrofishing Safety Certification

Sept. 2002

American Red Cross CPR/ First Aid Training

Sept 2003

Driver Safety

Sept. 2003

YMCA SCUBA Dive Certification (Advanced )

July 2000

OSHA 40 hour Course

Spring 2000 
Field Work Skills

Boat Electroshocking

Fish Fixation

Hydroacoustics

Stream Survey Techniques

Larval Light Traps

Radio Telemetry
Hess Sampling

WV DNR Lock Rotenone Survey

SCUBA Diving

Water Quality and Velocity Measures

Fish Identification of West Virginia Species

Boat driving, trailering, and navigation

Net Use Including Gill, Fyke, and Seine

Computer Skills: Excel, Word, Power Point, SPSS, SAS, Front Page Web Design, Arc GIS, ArcView, GPS

\section{Appointments \& Activities}

- Vice President: 2003 - 2004 term

West Virginia University American Fisheries Society Student Sub-Unit, Morgantown, WV Faculty Advisor : Dr. Kyle Hartman, 304-293-2941 ext 2494

This was WVU Fisheries Society's most successful year and for the first time was led by 4 female fisheries students and supported by over 30 members within the department. We organized several group activities and guest speakers, worked to attract new members, gained official standing with the University, and created a new website. Our largest accomplishment was the 2003 Student Colloquium (see below). As a result we were awarded Student Sub-Unit of the year for the Southern Division and currently nominated for National Student Sub-Unit of the year for the American Fisheries Society. www.wvu.edu/ fisheries_society

- Organizational Committee Member $3^{\text {rd }}$ Annual Fisheries Student Colloquium, November 7-8, 2003, Morgantown, WV

I was part of a small group putting together this large fisheries student meeting. This two day event had over 100 students in attendance from the entire East Coast (Massachusetts to Florida) for presentations and socials as a means for fisheries students to meet. The colloquium required months of careful planning and funding solicitation and suffered only from an excess of success. A review of the meeting is listed on our web site (www.wvu.edu/ fisheries_society).

- Girls Team Captain (1999 - 2000) and Team Member (1998 - 2001) Alfred University Alpine Ski Team

I was captain of the Alfred Univ. Woman's Alpine Ski Team. I arranged team activities, communicated between members and coaches and prepared for meets. I voluntarily provided materials displayed within the athletic department during the season for both the men's and women's teams as a way to boost acknowledgement of our exceptional accomplishments.

* Monroe Community College Woman's Volleyball Team (1997) 


\section{Relevant Course Work}

Fish Ecology (in process)

Limnology A-

Fisheries Techniques A

Fish Management A

Surficial Geology B+

Environmental Economics B-

Environmental Studies B-
Statistics II B

Fish Physiology B

Plate Tectonics A-

Hydrogeology A-

Ethics B

Geology \& Man A-

Oceanography $\mathrm{C}+$

Environmental Research Procedures B

Botany $\mathrm{C}+$

Colorado Plateau +2 week field trip (May 2001) A

Aquatic Foodweb Biogeochemistry (N:P Dynamics) A

Syracuse University Environmental Science and Forestry ( Spring 2002 )

Molecular Genetics of Eukaryotes B, Biometry B, Ecology B

Indiana University of Pennsylvania ( Fall 2001 )

Total Graduate Level Fisheries Related Credits : 35 Semester Hours 
* Evaluation of Artificial Structure use by Fish in the Kanawha River, WV

Study fish populations via electrofishing for their use of structures implanted by the Army Corp of Engineers as a part of mitigation for expanded locks in the Marmet Pool. Fish may use structures as a source of cover from predation and high flow events. Presentations include:

American Fisheries Society Southern Division Meeting Student Presenter, Wilmington, SC

West Virginia University Seminar Presenter, Morgantown, WV

Tri-State Meeting (WV, KY, VA State Chapters) Presenter, Ashland, KY

$2002-2004$

Feb 2003

April 2003 \& 2004

March 2003

Freshwater Sponges in the St. Lawrence River

My undergraduate senior project was a study of freshwater sponges and received an honors award. Data collection occurred via SCUBA diving to study freshwater sponge populations and localized water clarity. Sponges increased in surface area cover with greater water clarity. The project generated a large amount of local interest due to its uniqueness being one of the few quantitative freshwater sponge studies. Presentations include:

St. Lawrence Environmental Institute $8^{\text {th }}$ Annual International Conference Presenter, Cornwall, Ontario

Watertown Daily Times Interviewed for Newspaper Article, Watertown, NY

May 2001

Feb 2002

SCUBA Dive Symposium Guest Speaker, Watertown, NY

Feb 2002

Save of the River Meeting Guest Speaker, Clayton, NY

July 2002 


\section{References}

- Dr. Kyle Hartman

Title: Assistant Professor

Relation: Masters Advisor

- Dr. Patricia Mazik

Title: Cooperative Fish and Wildlife

Research Unit Leader

Relation: Masters Committee Member

- Dawn Kirk, M.S.

Title: Fisheries Biologist

Relation: Supervisor
West Virginia University

Dept. of Wildlife and Fisheries

Morgantown, WV 26506

(304) 293-2941 extension 2494

hartman@wvu.edu

West Virginia University

Morgantown, WV 26506

(304) 293-2941 extension 2431

pmazik@wvu.edu

US Forest Service

Roanoke, Virginia 24019

Phone (Glennwood, VA) 540-291-2188

dkirk@fs.fed.us 